Waste Site Reclassification Form

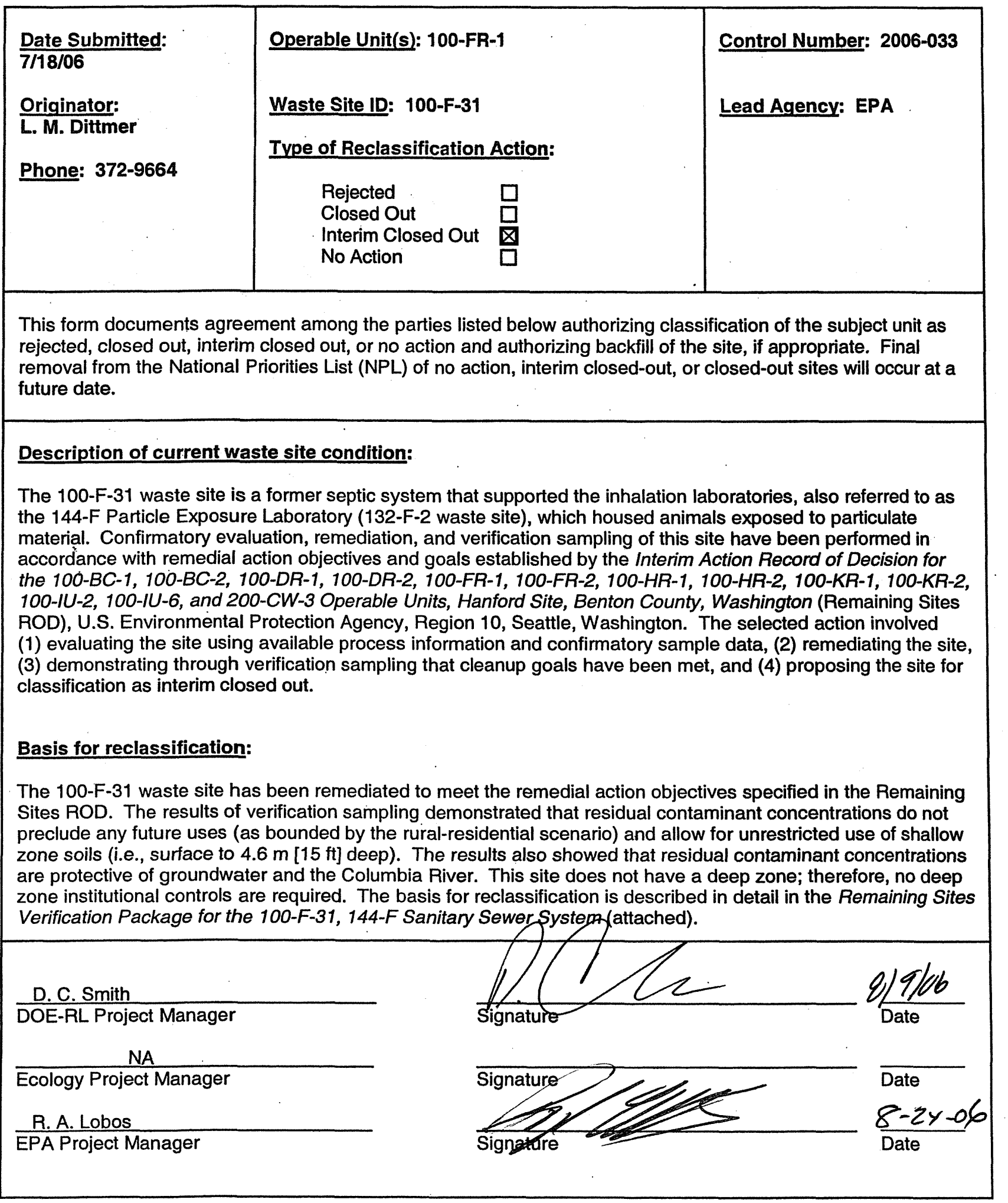




\section{REMAINING SITES VERIFICATION PACKAGE FOR THE 100-F-31, 144-F SANITARY SEWER SYSTEM \\ Attachment to Waste Site Reclassification Form 2006-033}

August 2006 


\section{REMAINING SITES VERIFICATION PACKAGE FOR THE 100-F-31, 144-F SANITARY SEWER SYSTEM}

\section{EXECUTIVE SUMMARY}

The 100-F-31 septic system was located in the 100-FR-1 Operable Unit within the former Pacific Northwest Laboratory's Experimental Animal Farm site. The 100-F-31 septic system supported the inhalation laboratories, also referred to as the 144-F Particle Exposure Laboratory (132-F-2 waste site), which housed animals exposed to particulate material. The 144-F Building was a one-story concrete block building with an office and six laboratories and included indoor and outdoor animal runs. The 100-F-31 septic system was located directly south of the 144-F Building and approximately $20 \mathrm{~m}(65 \mathrm{ft})$ west of the 107-F Retention Basin.

The 100-F-31 waste site was evaluated during 2004 confirmatory sampling efforts to evaluate if remedial action would be required at the site. Based on the results and field observations, it was determined that the 100-F-31 waste site required remedial action. Remediation of the 100-F-31 waste site consisted of the removal of the septic system, drain field, associated piping, and overburden material. Approximately 350 bank cubic meters (460 bank cubic yards) of material was excavated and disposed at the Environmental Restoration Disposal Facility.

Following excavation of the $100-\mathrm{F}-31$ septic system site, verification sampling was performed on February 6, 2006. One of the ten verification samples indicated the presence of aroclor-1248 at a concentration exceeding the direct exposure cleanup level. Additional site remediation was performed at the north end of the excavation, in the area of the residual contamination. A second set of statistical samples was collected from the septic system remediation footprint on May 17, 2006, and analyzed for polychlorinated biphenyls. The results of both sampling events indicated that the waste removal action achieved compliance with the remedial action objectives for the 100-F-31 waste site. A summary of the cleanup evaluation for the soil results against the applicable criteria is presented in Table ES-1. The results of the verification sampling are used to make reclassification decisions for the 100-F-31 site in accordance with the TPA-MP-14 (DOE-RL 1998) procedure.

In accordance with this evaluation, the verification sampling results support a reclassification of this site to interim closed out. The current site conditions achieve the remedial action objectives and the corresponding remedial action goals established in the Remedial Design Report/Remedial Action Work Plan for the 100 Area (DOE-RL 2005b) and the Interim Action Record of Decision for the 100-BC-1, 100-BC-2, 100-DR-1, 100-DR-2, 100-FR-1, 100-FR-2, 100-HR-1, 100-HR-2, 100-KR-1, 100-KR-2, 100-IU-2, 100-IU-6, and 200-CW-3 Operable Units, Hanford Site, Benton County, Washington (Remaining Sites ROD) (EPA 1999). The results of verification sampling show that residual contaminant concentrations do not preclude any future uses (as bounded by the rural-residential scenario) and allow for unrestricted use of shallow zone soils (i.e., surface to

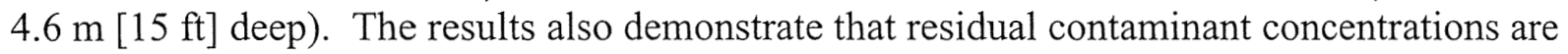
protective of groundwater and the Columbia River. This site does not have a deep zone; therefore, no deep zone institutional controls are required. 
Table ES-1. Summary of Remedial Action Goals for the 100-F-31 Site. (2 Pages)

\begin{tabular}{|c|c|c|c|}
\hline $\begin{array}{l}\text { Regulatory } \\
\text { Requirement }\end{array}$ & Remedial Action Goals & Results & $\begin{array}{l}\text { Remedial } \\
\text { Action } \\
\text { Objectives } \\
\text { Attained? }\end{array}$ \\
\hline $\begin{array}{l}\text { Direct Exposure - } \\
\text { Radionuclides }\end{array}$ & $\begin{array}{l}\text { Attain } 15 \mathrm{mrem} / \mathrm{yr} \text { dose rate above } \\
\text { background over } 1,000 \text { years. }\end{array}$ & $\begin{array}{l}\text { No radionuclide COPCs were } \\
\text { detected in the verification samples } \\
\text { for this site. }\end{array}$ & Yes \\
\hline $\begin{array}{l}\text { Direct Exposure - } \\
\text { Nonradionuclides }\end{array}$ & $\begin{array}{l}\text { Attain individual } \mathrm{COC} / \mathrm{COPC} \\
\text { RAGs. }\end{array}$ & $\begin{array}{l}\text { All individual COC/COPC } \\
\text { concentrations are below the direct } \\
\text { exposure criteria. }\end{array}$ & Yes \\
\hline \multirow[t]{4}{*}{$\begin{array}{l}\text { Risk Requirements - } \\
\text { Nonradionuclides }\end{array}$} & $\begin{array}{l}\text { Attain a hazard quotient of }<1 \text { for } \\
\text { all individual noncarcinogens. }\end{array}$ & $\begin{array}{l}\text { All individual hazard quotients are } \\
\text { less than } 1 .\end{array}$ & \multirow{4}{*}{ Yes } \\
\hline & $\begin{array}{l}\text { Attain a cumulative hazard } \\
\text { quotient of }<1 \text { for noncarcinogens. }\end{array}$ & $\begin{array}{l}\text { The cumulative hazard quotient } \\
\left(4.8 \times 10^{-2}\right) \text { is less than } 1 \text {. }\end{array}$ & \\
\hline & $\begin{array}{l}\text { Attain an excess cancer risk of } \\
<1 \times 10^{-6} \text { for individual } \\
\text { carcinogens. }\end{array}$ & $\begin{array}{l}\text { The excess cancer risk values for } \\
\text { individual carcinogens are less than } \\
1 \times 10^{-6} \text {. }\end{array}$ & \\
\hline & $\begin{array}{l}\text { Attain a cumulative excess cancer } \\
\text { risk of }<1 \times 10^{-5} \text { for carcinogens. }\end{array}$ & $\begin{array}{l}\text { The total excess cancer risk value } \\
\left(1.5 \times 10^{-6}\right) \text { is less than } 1 \times 10^{-5} \text {. }\end{array}$ & \\
\hline \multirow[t]{4}{*}{$\begin{array}{l}\text { Groundwater/River } \\
\text { Protection - } \\
\text { Radionuclides }\end{array}$} & $\begin{array}{l}\text { Attain single } \mathrm{COC} / \mathrm{COPC} \\
\text { groundwater and river protection } \\
\text { RAGs. }\end{array}$ & \multirow[t]{4}{*}{$\begin{array}{l}\text { No radionuclide COPCs were } \\
\text { detected in the verification samples } \\
\text { for this site. }\end{array}$} & \multirow{4}{*}{ Yes } \\
\hline & $\begin{array}{l}\text { Attain national primary drinking } \\
\text { water standards: } 4 \text { mrem/yr } \\
\text { (beta/gamma) dose rate to target } \\
\text { receptor/organs. }^{\text {a }}\end{array}$ & & \\
\hline & $\begin{array}{l}\text { Meet drinking water standards for } \\
\text { alpha emitters: the most stringent } \\
\text { of } 15 \mathrm{pCi} / \mathrm{L} \text { MCL or } 1 / 25 \text { th of the } \\
\text { derived concentration guides from } \\
\text { DOE Order } 5400.5^{\text {b }}\end{array}$ & & \\
\hline & $\begin{array}{l}\text { Meet total uranium standard of } \\
30 \mu \mathrm{g} / \mathrm{L}\left(21.2 \mathrm{pCi} / \mathrm{L}^{\mathrm{c}}\right) \text {. }\end{array}$ & & \\
\hline
\end{tabular}


Table ES-1. Summary of Remedial Action Goals for the 100-F-31 Site. (2 Pages)

\begin{tabular}{|l|l|l|l|}
\hline \multicolumn{1}{|c|}{$\begin{array}{c}\text { Regulatory } \\
\text { Requirement }\end{array}$} & Remedial Action Goals & Results & $\begin{array}{c}\text { Remedial } \\
\text { Action } \\
\text { Objectives } \\
\text { Attained? }\end{array}$ \\
\hline $\begin{array}{l}\text { Groundwater/River } \\
\text { Protection - }\end{array}$ & $\begin{array}{l}\text { Attain individual nonradionuclide } \\
\text { groundwater and river cleanup } \\
\text { requirements. }\end{array}$ & $\begin{array}{l}\text { Statistical results for lead are above } \\
\text { groundwater and river protection } \\
\text { RAGs. However, results of the } \\
100 \text { Area Analogous Sites } R E S R A D \\
\text { Calculations (BHI 2005) indicate } \\
\text { that this constituent will not reach } \\
\text { groundwater (and, therefore, the } \\
\text { Columbia River) within 1,000 years. } \\
\text { Therefore, the residual } \\
\text { concentrations achieve the RAOs for } \\
\text { groundwater and river protection. }\end{array}$ & Yes \\
\hline
\end{tabular}

a "National Primary Drinking Water Regulations" (40 Code of Federal Regulations 141).

${ }^{\mathrm{b}}$ Radiation Protection of the Public and the Environment (DOE Order 5400.5).

${ }^{\mathrm{c}}$ Based on the isotopic distribution of uranium in the 100 Areas, the $30 \mu \mathrm{g} / \mathrm{L} \mathrm{MCL}$ corresponds to $21.2 \mathrm{pCi} / \mathrm{L}$. Concentrationto-activity calculations are documented in Calculation of Total Uranium Activity Corresponding to a Maximum Contaminant Level for Total Uranium of 30 Micrograms per Liter in Groundwater (BHI 2001).

$\mathrm{COC}=$ contaminant of concern

$\mathrm{COPC}=$ contaminant of potential concern

$\mathrm{MCL}=$ maximum contaminant level (drinking water standard)

$\mathrm{RAG}=$ remedial action goal

$\mathrm{RAO}=$ remedial action objective

Soil cleanup levels were established in the Remaining Sites ROD (EPA 1999) based on a limited ecological risk assessment. Although not required by the Remaining Sites ROD, a comparison against ecological risk screening levels has been made for the site contaminants of concern, contaminants of potential concern, and other constituents. Screening levels were not exceeded for the site constituents, with the exception of boron, cadmium, vanadium, and lead. Exceedance of screening values does not necessarily indicate the existence of risk to ecological receptors. It is believed that the presence of these constituents does not pose a risk to ecological receptors as concentrations of lead, cadmium, and vanadium are within the range of Hanford Site background levels, and boron concentrations are consistent with those seen elsewhere at the Hanford Site (no established background value is available for boron). A baseline risk assessment for the river corridor portion of the Hanford Site began in 2004, which includes a more complete quantitative ecological risk assessment. That baseline risk assessment will be used to support the final closeout decision for the 100-F-31 waste site. 


\section{REMAINING SITES VERIFICATION PACKAGE FOR THE 100-F-31, 144-F SANITARY SEWER SYSTEM}

\section{STATEMENT OF PROTECTIVENESS}

This report demonstrates that the 100-F-31, 144-F Sanitary Sewer System waste site meets the objectives for interim closure as established in the Remedial Design Report/Remedial Action Work Plan for the 100 Area (RDR/RAWP) (DOE-RL 2005b) and the Interim Action Record of Decision for the 100-BC-1, 100-BC-2, 100-DR-1, 100-DR-2, 100-FR-1, 100-FR-2, 100-HR-1, 100-HR-2, 100-KR-1, 100-KR-2, 100-IU-2, 100-IU-6, and 200-CW-3 Operable Units, Hanford Site, Benton County, Washington (Remaining Sites ROD) (EPA 1999). The results of verification sampling show that residual contaminant concentrations do not preclude any future uses (as bounded by the rural-residential scenario) and allow for unrestricted use of shallow zone soils (i.e., surface to $4.6 \mathrm{~m}$ [15 ft] deep). The results also demonstrate that residual contaminant concentrations are protective of groundwater and the Columbia River. This site does not have a deep zone; therefore, no deep zone institutional controls are required.

\section{GENERAL SITE INFORMATION AND BACKGROUND}

The 100-F-31 septic system is located in the 100-FR-1 Operable Unit within the former Pacific Northwest Laboratory's Experimental Animal Farm site and supported the 144-F Building. The 100-F Area included laboratories that performed radiological studies on various species of animals. The 100-F-31 septic system supported the inhalation laboratories, also referred to as the 144-F Particle Exposure Laboratory (132-F-2 waste site). These laboratories housed animals exposed to particulate material (WHC 1993). The 144-F Building was a one-story concrete block building with an office and six laboratories, and included indoor and outdoor animal runs. It is believed that the 100-F-31 site received both animal and human septic waste from the 144-F Building. The 100-F experimental farm was abandoned when Pacific Northwest Laboratory moved its biological studies to the 300 Area and the 144-F facility was decommissioned and demolished in 1977 (WHC 1991), leaving the septic system in place.

The septic system was located directly south of the 144-F Building and approximately $20 \mathrm{~m}$ $(65 \mathrm{ft}$ ) west of the 107-F Retention Basin (Figure 1). During confirmatory sampling, the lateral dimensions of the tank were observed to be approximately $2.6 \mathrm{~m}$ by $1.1 \mathrm{~m}(8.5 \mathrm{ft}$ by $3.5 \mathrm{ft})$, contrary to the larger size described in the plumbing and detail drawing (GE 1963). The site was determined to require remediation after elevated levels of metals, polycyclic aromatic hydrocarbons (PAHs), and polychlorinated biphenyls (PCBs) were detected by confirmatory sampling in 2004 (Feist 2005). The 100-F-31 waste site was remediated in 2005 to an approximate depth of $3 \mathrm{~m}(9.8 \mathrm{ft})$. 
Figure 1. 100-F-31 (144-F) Site Location Map.

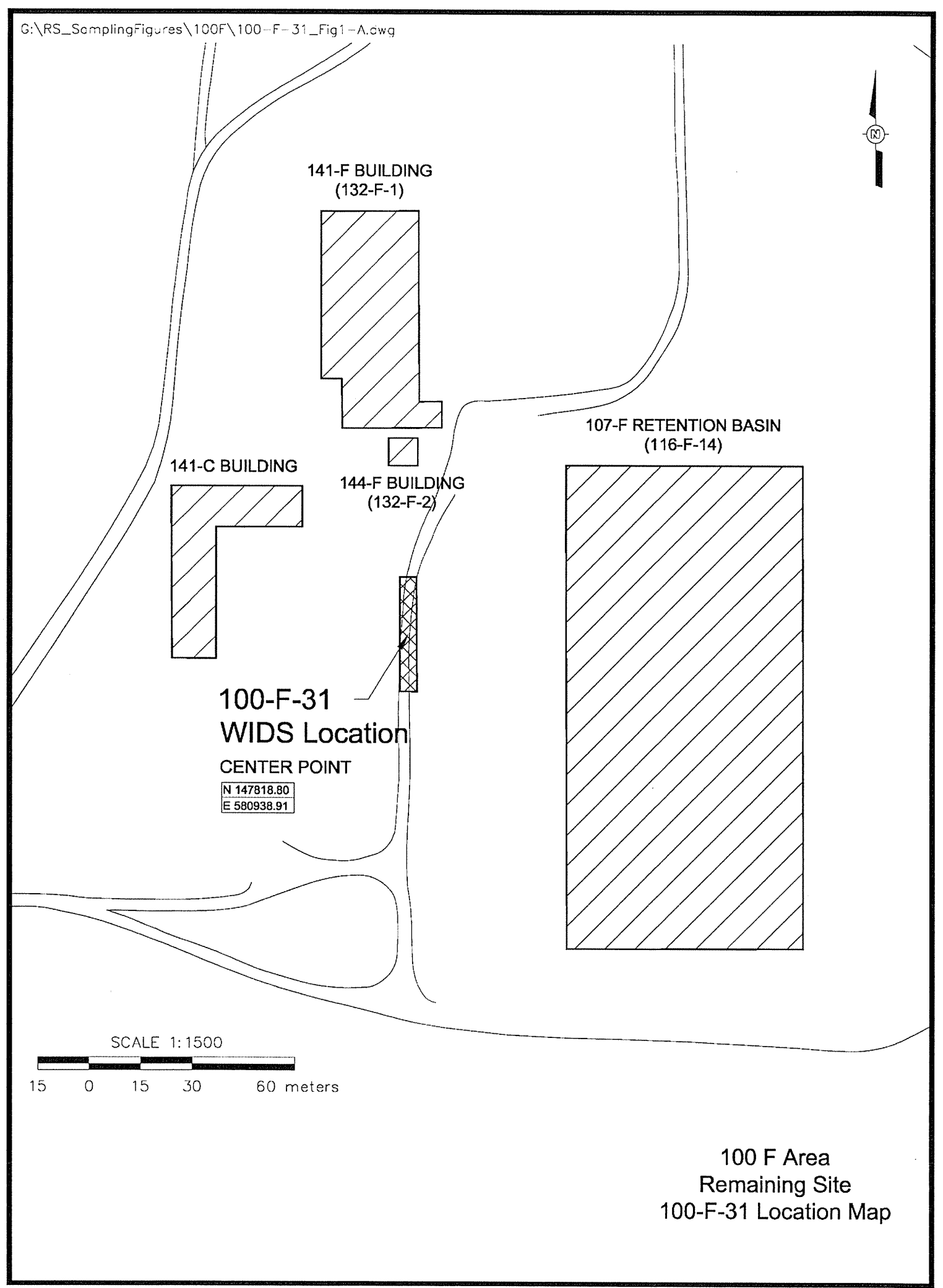




\section{CONFIRMATORY SAMPLING ACTIVITIES}

The 100-F-31 waste site was evaluated during 2004 confirmatory sampling efforts to determine if remedial action would be required at the site. Based on site visit observations, the geophysical survey information, and the results of confirmatory sampling, a decision was made that remedial action at the site was necessary. The following subsections provide additional discussion of the information used to develop the confirmatory sampling design. The results of confirmatory sampling are also summarized to provide support for development of the remedial action strategy and verification sample design.

\section{Geophysical Investigation}

A geophysical survey was performed at the 100-F-31 waste site in April 2004 using groundpenetrating radar, electromagnetic induction, and magnetometery (Bergstrom et al. 2004). The survey identified subsurface anomalies consistent with the documented locations of the tank and drain field, but with smaller footprints than those suggested in documentation (Figure 2). Confirmatory sampling and remediation activities confirmed that these features were smaller than previously supposed.

\section{Contaminants of Potential Concern for Confirmatory Sampling}

The contaminants of potential concern (COPCs) for the 100-F-31 septic system were identified based on existing historical information. The COPC list identified in the 100 Area Remedial Action Sampling and Analysis Plan (SAP) (DOE-RL 2005a) includes cobalt-60, cesium-137, europium-152, europium-154, europium-155, plutonium-238, plutonium-239/240, strontium-90, uranium-234, uranium-235, hexavalent chromium, mercury, lead, and PAHs. As a result of further evaluation of this site, a decision was made to add arsenic, barium, cadmium, total chromium, selenium, silver, and PCBs as COPCs.

\section{Confirmatory Sample Design}

Historical data, process knowledge, geophysical survey results, and site visit information were used to develop a site-specific confirmatory sampling design with focused sampling of residual septic system contents at the 100-F-31 site (BHI 2004b). Excavation and confirmatory sampling was performed on October 14 and 15, 2004, as described in the sampler's field logbook (BHI 2004a). During field activities, it was discovered that the septic tank had not been previously decommissioned, and samples were collected from residual tank contents. A mastic sealant was identified on the septic tank lid and a sample collected from this material. Gray-stained soil was observed during excavation at the eastern side of the septic tank, and a sample was collected at this location at an approximate depth of $0.6 \mathrm{~m}(2 \mathrm{ft})$. Field screening for volatile organic compounds (VOCs) was conducted during excavation and confirmatory sampling activities. No VOCs were detected, and therefore VOCs were excluded as COPCs. No asbestos-containing material was observed during sampling, and therefore asbestos was also excluded as a COPC. 
Figure 2. Interpreted Geophysical Survey Results and Confirmatory Sampling Locations at the 100-F-31 Waste Site.

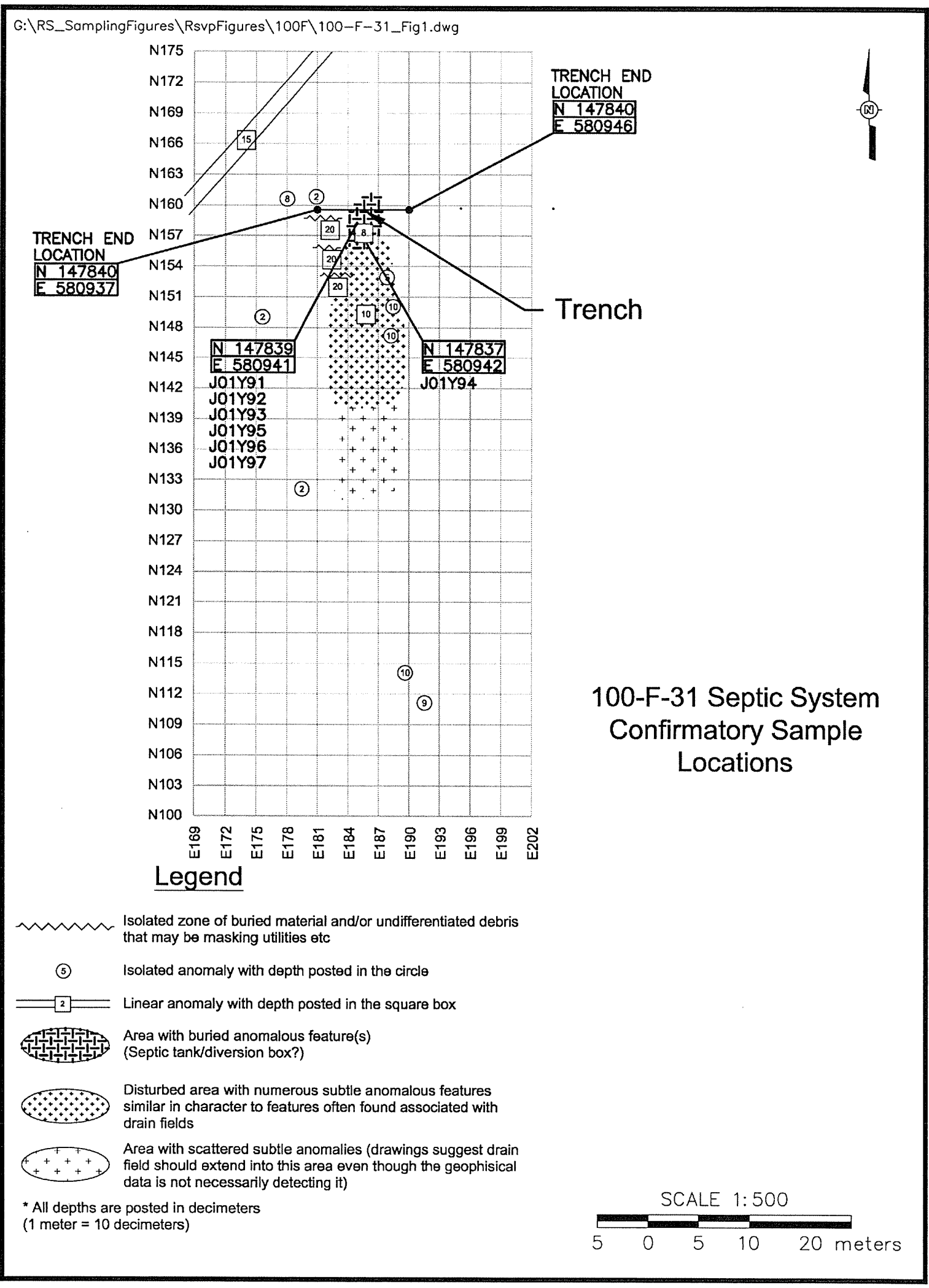


A summary of the samples collected and laboratory analyses performed is provided in Table 1 . Figure 2 identifies the sample locations.

Table 1. October 2004 Confirmatory Sample Summary for the 100-F-31 Septic System.

\begin{tabular}{|c|c|c|c|c|c|}
\hline $\begin{array}{l}\text { Sample } \\
\text { Location }\end{array}$ & $\begin{array}{l}\text { Sample } \\
\text { Media }\end{array}$ & $\begin{array}{l}\text { Sample } \\
\text { Number }\end{array}$ & $\begin{array}{l}\text { Coordinate } \\
\text { Locations }\end{array}$ & $\begin{array}{l}\text { Depth } \\
\text { (bgs) }\end{array}$ & Sample Analysis \\
\hline \multirow[t]{2}{*}{ Septic tank } & \multirow{2}{*}{$\begin{array}{c}\text { Tank } \\
\text { contents }\end{array}$} & J01Y91 & \multirow{2}{*}{$\begin{array}{l}\text { N } 147839 \\
\text { E } 580941\end{array}$} & \multirow{2}{*}{$\begin{array}{c}2.4 \mathrm{~m} \\
(7.9 \mathrm{ft})\end{array}$} & $\begin{array}{l}\text { GEA, gross alpha, gross beta, mercury, ICP } \\
\text { metals, PAH, SVOA, and PCB }\end{array}$ \\
\hline & & J01Y96 & & & Hexavalent chromium \\
\hline \multirow{2}{*}{$\begin{array}{l}\text { Duplicate of } \\
\text { J01Y91 }\end{array}$} & \multirow{2}{*}{$\begin{array}{c}\text { Tank } \\
\text { contents }\end{array}$} & J01Y92 & \multirow{2}{*}{$\begin{array}{l}\text { N } 147839 \\
\text { E } 580941\end{array}$} & \multirow{2}{*}{$\begin{array}{c}2.4 \mathrm{~m} \\
(7.9 \mathrm{ft})\end{array}$} & $\begin{array}{l}\text { GEA, gross alpha, gross beta, mercury, ICP } \\
\text { metals, PAH, SVOA, and PCB }\end{array}$ \\
\hline & & J01Y97 & & & Hexavalent chromium \\
\hline $\begin{array}{l}\text { Septic tank } \\
\text { lid sealant }\end{array}$ & Mastic & J01Y95 & $\begin{array}{l}\text { N } 147839 \\
\text { E } 580941\end{array}$ & $\begin{array}{l}1.2 \mathrm{~m} \\
(4 \mathrm{ft})\end{array}$ & $\mathrm{PCB}$ and $\mathrm{PAH}$ \\
\hline $\begin{array}{l}\text { East side of } \\
\text { diversion } \\
\text { box }\end{array}$ & $\begin{array}{l}\text { Stained } \\
\text { soil }\end{array}$ & J01Y94 & $\begin{array}{l}\text { N } 147837 \\
\text { E } 580942\end{array}$ & $\begin{array}{l}0.6 \mathrm{~m} \\
(2 \mathrm{ft})\end{array}$ & ICP metals, PCB, and PAH \\
\hline $\begin{array}{l}\text { Equipment } \\
\text { blank }\end{array}$ & Silica sand & J01Y93 & N/A & N/A & $\begin{array}{l}\text { Mercury, ICP metals, PAH, SVOA, and } \\
\text { PCB }\end{array}$ \\
\hline $\begin{array}{l}\text { bgs }=\text { below } \\
\mathrm{GEA}=\text { gamma } \\
\mathrm{ICP}=\text { inducti } \\
\mathrm{N} / \mathrm{A}=\text { not app }\end{array}$ & $\begin{array}{l}\text { round surface } \\
\text { energy analys } \\
\text { ely coupled p } \\
\text { icable }\end{array}$ & & ST & $\begin{aligned} & =\text { polyc } \\
\mathrm{A} & =\text { semi }\end{aligned}$ & $\begin{array}{l}\text { lorinated biphenyl } \\
\text { latile organic analysis }\end{array}$ \\
\hline
\end{tabular}

\section{Confirmatory Sampling Results}

Confirmatory samples were analyzed using analytical methods approved by the

U.S. Environmental Protection Agency (EPA), and the results were compared against the cleanup criteria specified in the RDR/RAWP (DOE-RL 2005b). The results are stored in the Environmental Restoration (ENRE) project-specific database prior to archiving in the Hanford Environmental Information System (HEIS) and are included in Appendix A.

Analytical results for the samples collected from the 100-F-31 septic tank and stained soils indicated that contaminant concentrations of several PAHs, mercury, hexavalent chromium, and aroclor-1254 failed the direct exposure remedial action goals (RAGs). Additionally, several constituents were detected above the soil RAGs for the protection of groundwater and the Columbia River, including multiple metals, multiple PAHs, and aroclor-1254. Cesium-137 was the only radionuclide detected at the 100-F-31 waste site; however, it was not detected at a concentration in exceedance of the dose-equivalence lookup values. Because multiple contaminants were detected above direct exposure RAGs and soil RAGs for the protection of groundwater and the Columbia River, it was determined that remedial action was necessary at the 100-F-31, 144-F Sanitary Sewer System (Feist 2005). 


\section{REMEDIAL ACTION SUMMARY}

Remediation of the 100-F-31 waste site consisted of the removal of the septic tank, drain field, associated piping, and overburden material. Approximately 350 bank cubic meters ( 460 bank cubic yards) of material was excavated and disposed at the Environmental Restoration Disposal Facility. The site was excavated to a maximum depth of $3.0 \mathrm{~m}(9.8 \mathrm{ft})$ below ground surface. The pre- and post-excavation topographic surveys for the 100-F-31 site are provided in Figures 3 and 4 , respectively.

In-process samples of soil and suspect waste materials were collected during site remediation as needed to support waste characterization and evaluation of the waste profile for disposal of excavated material. The analytical results for these samples are provided in Appendix A.

Following excavation of the 100-F-31 waste site, verification sampling was performed on February 6, 2006 in accordance with the Verification Work Instruction for the 100-F-31 Septic System, 144-F Sanitary Sewer System (WCH 2005). Analytical results from the verification soil samples indicated that the northern side of the excavation contained residual contamination of aroclor-1248. The residual PCB was detected at a concentration of $7.3 \mathrm{mg} / \mathrm{kg}$, which is in exceedance of the direct exposure RAG $(0.5 \mathrm{mg} / \mathrm{kg})$. Additional remediation was performed in April 2006 and the PCB-contaminated soil was removed from the north sidewall of the 100-F-31 excavation footprint. A second set of verification samples were collected as documented in WCH (2006a) on May 17, 2006. These samples were analyzed for PCBs to verify that the subsequent remediation efforts had successfully removed the contamination. Within this remaining sites verification package, Phase I verification sampling refers to the soil samples collected on February 6, 2006, after completion of the initial remediation efforts. The Phase II verification sampling refers to the PCB sampling conducted on May 17, 2006.

\section{VERIFICATION SAMPLING ACTIVITIES}

RAGs are the specific numeric goals against which the cleanup verification data are evaluated to demonstrate attainment of the remedial action objectives for the site. Verification sampling for the 100-F-31 site was performed on February 6, 2006 (Phase I) and May 17, 2006 (Phase II), to collect data to determine if the RAGs had been met. Based on statistical evaluation of the resulting data, the residual contaminant concentrations meet the cleanup criteria specified in the RDR/RAWP (DOE-RL 2005b) and the Remaining Sites ROD (EPA 1999). The following subsections provide additional discussion of the information used to develop the verification sampling design. The results of verification sampling are also summarized to support interim closure of the site.

\section{Contaminants of Concern and Contaminants of Potential Concern}

The results of confirmatory sampling were used to determine the contaminants of concern (COCs) and COPCs for verification sampling. The COCs include those constituents that were detected above direct exposure RAGs by confirmatory sampling and are listed in Table 2 . 


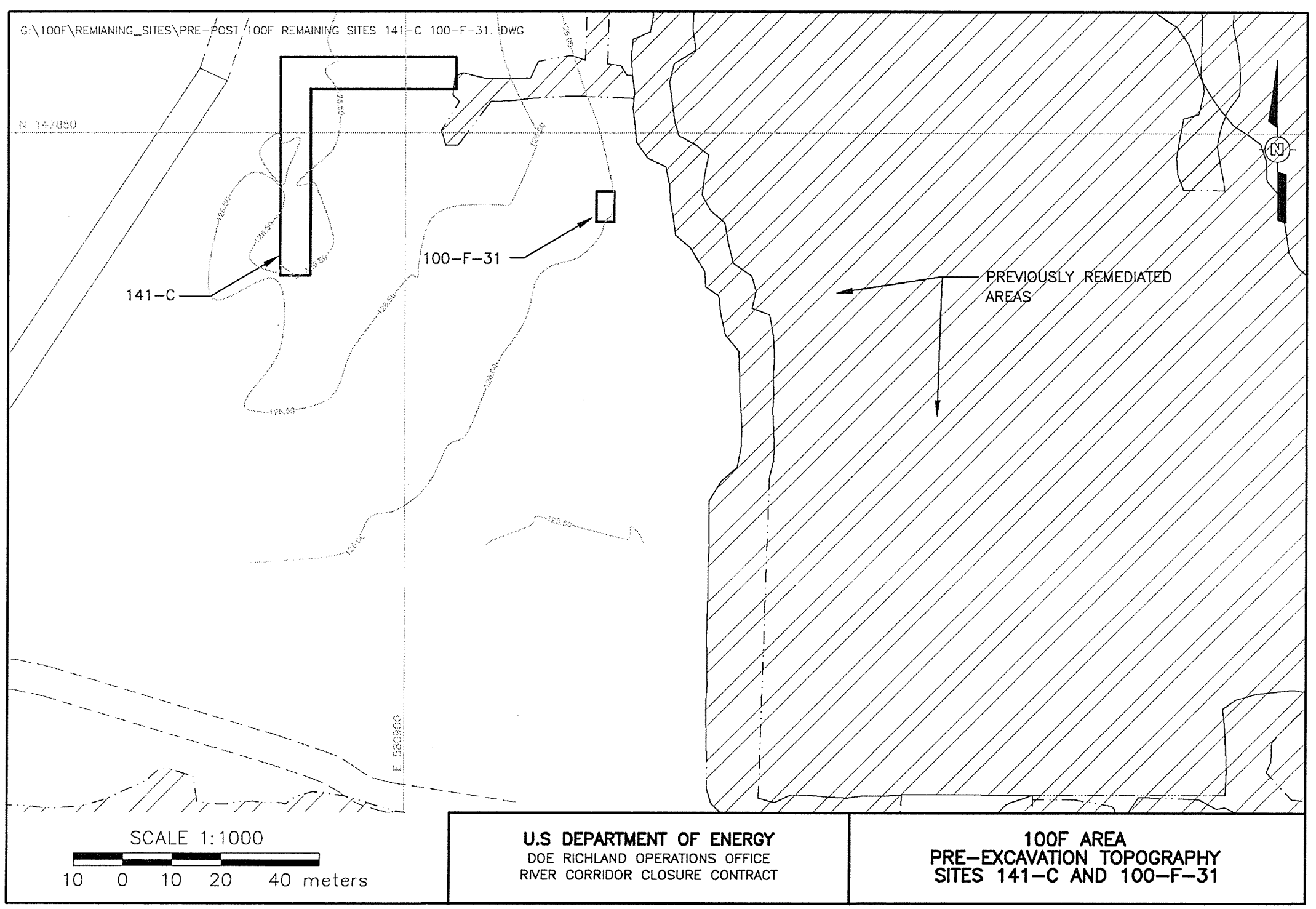




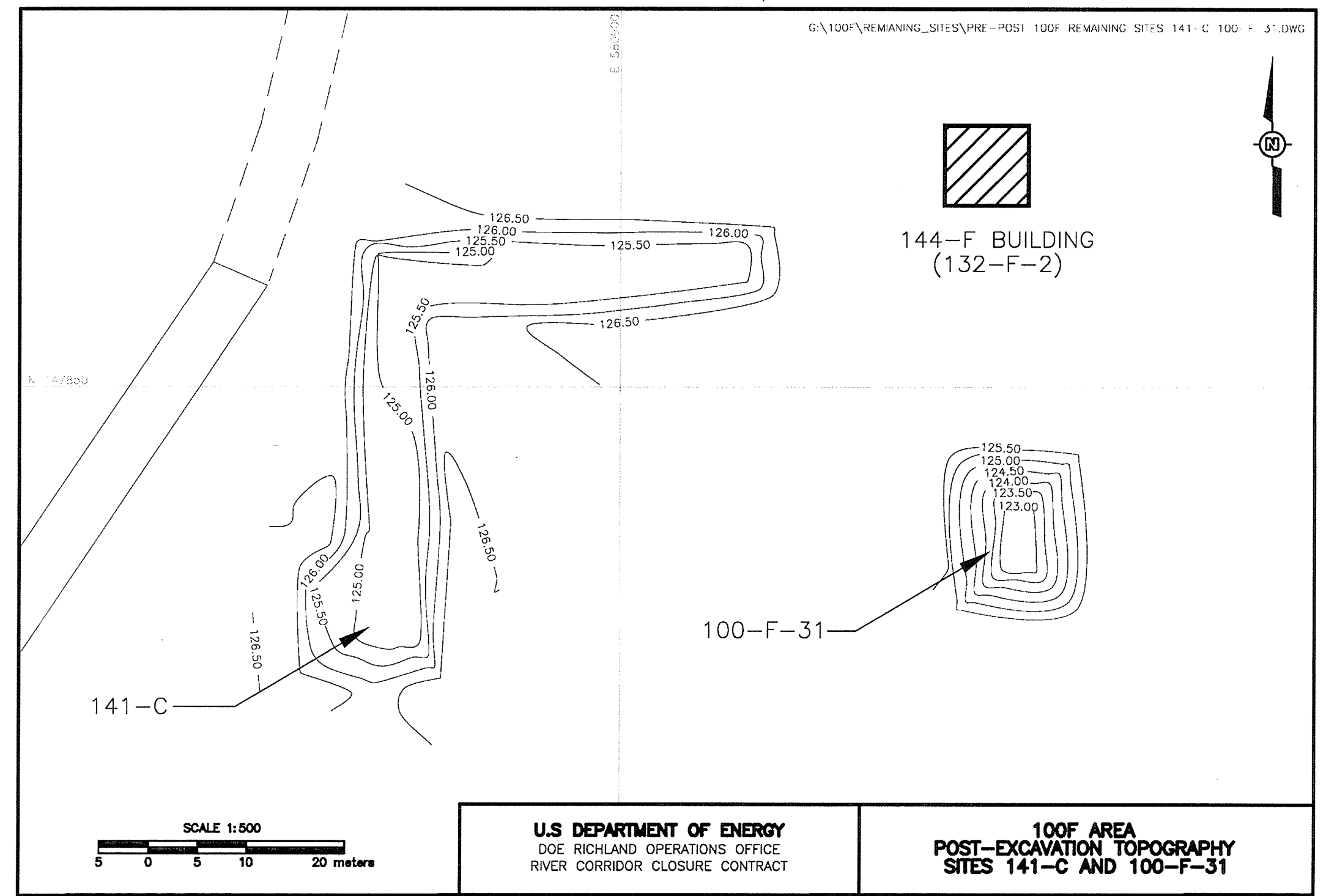


All of the constituents that were detected above soil RAGs for groundwater and/or river protection but below direct exposure RAGs are not predicted to reach groundwater (and thus the Columbia River) within 1,000-years based on the 100 Area Analogous Sites RESRAD Calculations (BHI 2005). However, these constituents were retained as COPCs for verification sampling as identified in Table 2. Cesium-137, americium-241, and europium-152 were the only radionuclides detected in confirmatory or waste characterization sampling. While activity levels for these radionuclides were below dose-equivalence lookup values, they were also considered COPCs for verification sampling. Phase I verification soil samples were analyzed for the full list of COCs/COPCs listed in Table 2, whereas the verification soil samples collected during Phase II were analyzed for PCBs only.

Table 2. Contaminants of Concern and Contaminants of Potential Concern for Verification Sampling at the 100-F-31 Waste Site.

\begin{tabular}{|l|l|}
\hline Contaminants of Concern & \multicolumn{1}{|c|}{ Contaminants of Potential Concern } \\
\hline Hexavalent chromium & $\begin{array}{l}\text { Metals (antimony, barium, cadmium, chromium [total], copper, lead, } \\
\text { molybdenum, nickel, selenium, silver, and zinc) }\end{array}$ \\
\hline Mercury & $\begin{array}{l}\text { Semivolatile organic compounds (bis(2-ethylhexyl)phthalate and } \\
\text { carbazole) }\end{array}$ \\
\hline Aroclor-1254 & Cesium-137, americium-241, and europium-152 \\
\hline $\begin{array}{l}\text { Polyaromatic hydrocarbons } \\
\text { (included with semivolatile } \\
\text { organic analysis) }\end{array}$ & \\
\hline
\end{tabular}

\section{Verification Sampling Design}

This section describes the basis for selection of an appropriate sample design and determination of the number of verification samples that were collected. The post-excavation topographic survey (Figure 4) was used to determine the boundaries of the 100-F-31 remedial action for the purpose of verification sampling. The 100-F-31 waste site was sampled in two phases as a result of the elevated levels of the PCB detected during the first verification sampling event.

Additional remediation did not significantly alter the Phase I remediation footprint; therefore, the existing post-excavation survey was used for the Phase II verification sample design. The agreement for the Phase II sample design is documented in WCH (2006a). Both sample designs are presented in Figures 5 and 6, respectively.

The decision rule for demonstrating compliance with the cleanup criteria requires comparison of the true population mean, as estimated by the $95 \%$ upper confidence limit on the sample mean, with the cleanup level. Therefore, a statistical sampling design is the preferred verification sampling approach for this site because the distribution of potential residual soil contamination over the site is uncertain. The Washington State Department of Ecology publication Guidance on Sampling and Data Analysis Methods (Ecology 1995) recommends that systematic sampling with sample locations distributed over the entire study area be used. This sampling approach is referred to by the Washington State Department of Ecology as "area-wide sampling." 
Figure 5. Verification Soil Sampling Locations (Phase I).

0:\100F\1.0205^.cwg

144-F BUILDING

$(132-F-2)$

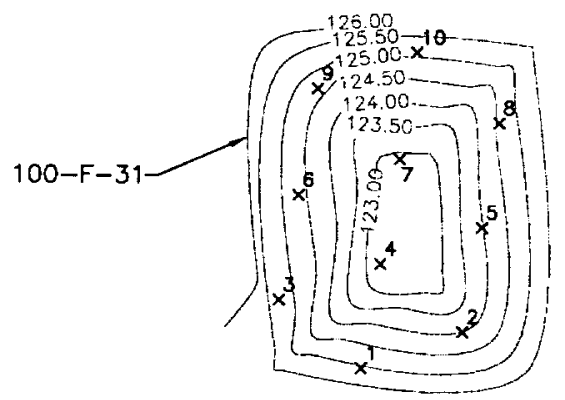

TABLE C-3. 100-F-31 VERIFICATION SAMPLE LOCATION COORDINATES

\begin{tabular}{|l|l|c|}
\hline SAMPLE LOCATION & $X$ COORDINATE & Y COORDINATE \\
\hline 1 & 580938.60 & 147827.40 \\
\hline 2 & 580943.50 & 147829.20 \\
\hline 3 & 580934.60 & 147830.70 \\
\hline 4 & 580939.50 & 147832.50 \\
\hline 5 & 580944.40 & 147834.30 \\
\hline 6 & 580935.50 & 147835.80 \\
\hline 7 & 580940.40 & 147837.60 \\
\hline 8 & 580945.20 & 147839.40 \\
\hline 9 & 580936.40 & 147841.00 \\
\hline 10 & 580941.20 & 147842.80 \\
\hline
\end{tabular}

\section{Legend}
$x^{1}$
Verification Sample Locations
SCALE 1: 400
100-F Area
100-F-31 Verification Sample
Location Map 
Figure 6. Verification Soil Sampling Locations (Phase II).

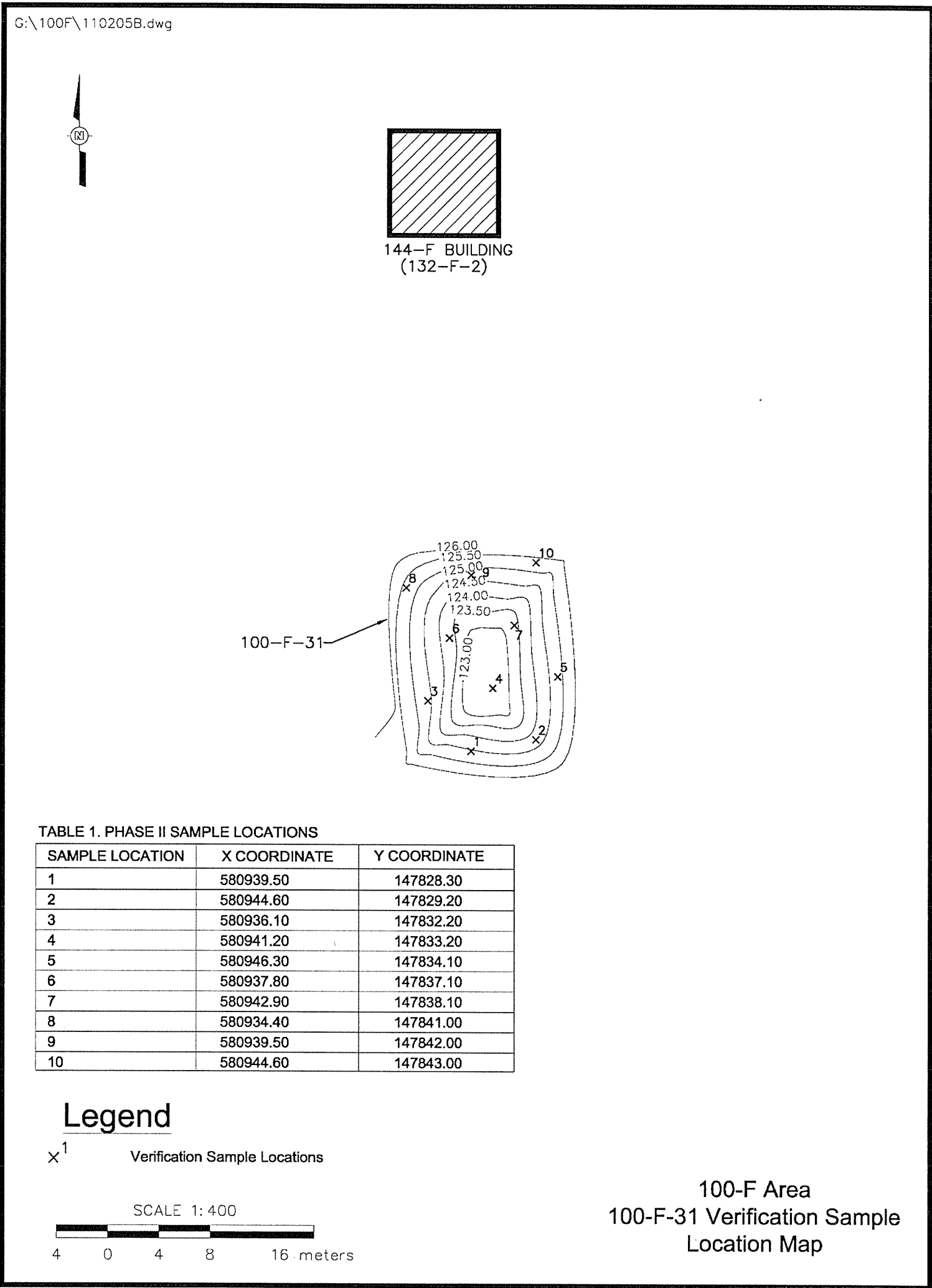


Visual Sample Plan ${ }^{1}$ (VSP) was used as a tool to develop the statistical sampling design for both Phase I and Phase II verification sampling efforts. The excavated area was delineated in VSP and used as the basis for location of a random-start systematic grid for verification soil sample collection. A total of 10 soil samples were collected on this grid within the remediation footprint for each phase of verification sampling. A triangular grid was selected for this investigation based on studies that indicate triangular grids are superior to square grids (Gilbert 1987). Additional discussion of development of the statistical verification sample design is provided in the 100-F-31 verification work instruction (WCH 2005).

Summaries of the samples collected for the two verification sampling events and the analyses performed are presented in Tables 3 and 4 . The soil sample locations were surveyed and staked prior to sample collection. All sampling was performed in accordance with ENV-1, Environmental Monitoring \& Management, to fulfill the requirements of the SAP (DOE-RL 2005a). One soil sample was collected at each location by collecting 25 aliquots of surficial soils

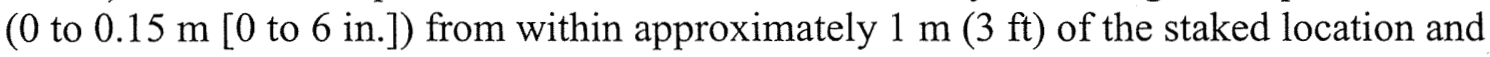
combining the aliquots into one sample. One duplicate sample was taken during each sampling event for quality control purposes.

\section{Verification Sampling Results}

Verification samples were analyzed using EPA-approved analytical methods. The 95\% upper confidence limit on the true population mean for residual concentrations of COCs and COPCs was calculated for the remediation footprint as specified by the RDR/RAWP (DOE-RL 2005b), with calculations provided in Appendix B. When a nonradionuclide COC or COPC was detected in fewer than $50 \%$ of the verification samples collected, the maximum detected value was used for comparison against RAGs. If no detections for a given $\mathrm{COC} / \mathrm{COPC}$ were reported in the data set, then no statistical evaluation or calculations were performed for that $\mathrm{COC} / \mathrm{COPC}$.

Comparisons of the statistical and maximum results for COCs and COPCs and the site RAGs for the remediation footprint are summarized in Tables $5 \mathrm{a}$ and $5 \mathrm{~b}$, respectively. Contaminants that were not detected by laboratory analysis are excluded from these tables. Calculated cleanup levels are not presented in the Model Toxics Control Act Cleanup Levels and Risk Calculations database under Washington Administrative Code (WAC) 173-340-740(3) for aluminum, calcium, iron, magnesium, potassium, silicon, and sodium; therefore, these constituents are not considered site COPCs. Potassium-40, radium-226, radium-228, thorium-228, and thorium-232 were detected in samples collected at the site, but are not considered within statistical calculations or Tables $5 \mathrm{a}$ and $5 \mathrm{~b}$, as these isotopes are not related to the operational history of the site. The laboratory-reported data results for all constituents are stored in the ENRE project-specific database prior to archiving in HEIS and are presented in Appendix B.

\footnotetext{
${ }^{1}$ Visual Sample Plan is a site map-based user-interface program that may be downloaded at http://dqo.pnl.gov.
} 
Table 3. Verification Sample Summary Table for the 100-F-31 Phase I Sampling.

\begin{tabular}{|c|c|c|c|}
\hline $\begin{array}{l}\text { Sample } \\
\text { Location }\end{array}$ & $\begin{array}{c}\text { Sample } \\
\text { Coordinates }\end{array}$ & $\begin{array}{l}\text { HEIS Sample } \\
\text { Number }\end{array}$ & Sample Analysis \\
\hline 1 & $\begin{array}{l}\text { N } 580938.6 \\
\text { E } 147827.4\end{array}$ & $\mathrm{~J} 112 \mathrm{D} 3$ & $\begin{array}{l}\text { ICP metals, mercury, hexavalent chromium, } \\
\text { PCB, SVOA, GEA }\end{array}$ \\
\hline 2 & $\begin{array}{l}\text { N } 580943.5 \\
\text { E } 147829.2\end{array}$ & $\mathrm{~J} 112 \mathrm{D} 4$ & $\begin{array}{l}\text { ICP metals, mercury, hexavalent chromium, } \\
\text { PCB, SVOA, GEA }\end{array}$ \\
\hline 3 & $\begin{array}{l}\text { N } 580934.6 \\
\text { E } 147830.7\end{array}$ & $\mathrm{~J} 112 \mathrm{D} 5$ & $\begin{array}{l}\text { ICP metals, mercury, hexavalent chromium, } \\
\text { PCB, SVOA, GEA }\end{array}$ \\
\hline 4 & $\begin{array}{l}\text { N } 580939.5 \\
\text { E } 147832.5\end{array}$ & J112D6 & $\begin{array}{l}\text { ICP metals, mercury, hexavalent chromium, } \\
\text { PCB, SVOA, GEA }\end{array}$ \\
\hline 5 & $\begin{array}{l}\text { N } 580944.4 \\
\text { E } 147834.3\end{array}$ & $\mathrm{~J} 112 \mathrm{D} 7$ & $\begin{array}{l}\text { ICP metals, mercury, hexavalent chromium, } \\
\text { PCB, SVOA, GEA }\end{array}$ \\
\hline 6 & $\begin{array}{l}\text { N } 580935.5 \\
\text { E } 147835.8\end{array}$ & $\mathrm{~J} 112 \mathrm{D} 8$ & $\begin{array}{l}\text { ICP metals, mercury, hexavalent chromium, } \\
\text { PCB, SVOA, GEA }\end{array}$ \\
\hline 7 & $\begin{array}{l}\text { N } 580940.4 \\
\text { E } 147837.6\end{array}$ & J112D9 & $\begin{array}{l}\text { ICP metals, mercury, hexavalent chromium, } \\
\text { PCB, SVOA, GEA }\end{array}$ \\
\hline 8 & $\begin{array}{l}\text { N } 580945.2 \\
\text { E } 147839.4\end{array}$ & $\mathrm{~J} 112 \mathrm{~F} 0$ & $\begin{array}{l}\text { ICP metals, mercury, hexavalent chromium, } \\
\text { PCB, SVOA, GEA }\end{array}$ \\
\hline 9 & $\begin{array}{l}\text { N } 580936.4 \\
\text { E } 147841.0\end{array}$ & $\mathrm{~J} 112 \mathrm{~F} 1$ & $\begin{array}{l}\text { ICP metals, mercury, hexavalent chromium, } \\
\text { PCB, SVOA, GEA }\end{array}$ \\
\hline 10 & $\begin{array}{l}\text { N } 580941.2 \\
\text { E } 147842.8\end{array}$ & $\mathrm{~J} 112 \mathrm{~F} 2$ & $\begin{array}{l}\text { ICP metals, mercury, hexavalent chromium, } \\
\text { PCB, SVOA, GEA }\end{array}$ \\
\hline $\begin{array}{l}\text { Duplicate at } \\
\text { location } 1\end{array}$ & $\begin{array}{l}\text { N } 580938.6 \\
\text { E } 147827.4\end{array}$ & $\mathrm{~J} 112 \mathrm{~F} 3$ & $\begin{array}{l}\text { ICP metals, mercury, hexavalent chromium, } \\
\text { PCB, SVOA, GEA }\end{array}$ \\
\hline $\begin{array}{l}\text { Equipment } \\
\text { blank }\end{array}$ & NA & $\mathrm{J} 112 \mathrm{~F} 4$ & ICP metals, mercury, SVOA \\
\hline
\end{tabular}

Source: Remaining Site Field Sampling, Logbook EFL-1174 (WCH 2006b).

GEA = gamma energy analysis NA = not applicable

HEIS = Hanford Environmental Information System $\quad \mathrm{PCB}=$ polychlorinated biphenyl

ICP = inductively coupled plasma $\quad$ SVOA $=$ semivolatile organic analysis 
Table 4. Verification Sample Summary Table for the 100-F-31 Phase II Sampling.

\begin{tabular}{|c|c|c|c|}
\hline Sample Location & $\begin{array}{c}\text { Sample } \\
\text { Coordinates }\end{array}$ & HEIS Number & $\begin{array}{c}\text { Sample } \\
\text { Analysis }\end{array}$ \\
\hline 1 & $\begin{array}{l}\text { N } 580939.5 \\
\text { E } 147828.3\end{array}$ & $\mathrm{~J} 12670$ & PCB \\
\hline 2 & $\begin{array}{l}\text { N } 580944.6 \\
\text { E } 147829.2\end{array}$ & $\mathrm{~J} 12671$ & PCB \\
\hline 3 & $\begin{array}{l}\text { N } 580936.1 \\
\text { E } 147832.2\end{array}$ & $\mathrm{~J} 12672$ & PCB \\
\hline 4 & $\begin{array}{l}\text { N } 580941.2 \\
\text { E } 147833.2\end{array}$ & $\mathrm{~J} 12673$ & PCB \\
\hline 5 & $\begin{array}{l}\text { N } 580946.3 \\
\text { E } 147834.1\end{array}$ & $\mathrm{~J} 12675$ & PCB \\
\hline 6 & $\begin{array}{l}\text { N } 580937.8 \\
\text { E } 147837.1\end{array}$ & $\mathrm{~J} 12676$ & PCB \\
\hline 7 & $\begin{array}{l}\text { N } 580942.9 \\
\text { E } 147838.1\end{array}$ & $\mathrm{~J} 12677$ & PCB \\
\hline 8 & $\begin{array}{l}\text { N } 580934.4 \\
\text { E } 147841.0\end{array}$ & $\mathrm{~J} 12678$ & PCB \\
\hline 9 & $\begin{array}{l}\text { N } 147841.0 \\
\text { E } 147842.0\end{array}$ & J12679 & PCB \\
\hline 10 & $\begin{array}{l}\text { N } 580944.6 \\
\text { E } 147843.0 \\
\end{array}$ & $\mathrm{~J} 12680$ & PCB \\
\hline $\begin{array}{c}\text { Duplicate at } \\
\text { location } 4\end{array}$ & $\begin{array}{l}\text { N } 580941.2 \\
\text { E } 147833.2\end{array}$ & $\mathrm{~J} 12674$ & PCB \\
\hline
\end{tabular}

Source: Remaining Site Field Sampling, Logbook EFL-1174 (WCH 2006c).

$\mathrm{PCB}=$ polychlorinated biphenyl

HEIS = Hanford Environmental Information System 
Table 5a. Comparison of Statistical Residual Contaminant Concentrations to Remedial Action Goals for the 100-F-31 Waste Site Excavated Area (Phase I).

\begin{tabular}{|c|c|c|c|c|c|c|}
\hline \multirow[b]{2}{*}{$\mathrm{COC} / \mathrm{COPC}$} & \multirow[b]{2}{*}{$\begin{array}{c}\text { Statistical } \\
\text { Result } \\
\text { (mg/kg) }\end{array}$} & \multicolumn{3}{|c|}{ Remedial Action Goals ${ }^{\mathrm{a}}$ (mg/kg) } & \multirow{2}{*}{$\begin{array}{l}\text { Does the } \\
\text { Statistical } \\
\text { Result } \\
\text { Exceed } \\
\text { RAGs? }\end{array}$} & \multirow{2}{*}{$\begin{array}{c}\text { Does the } \\
\text { Statistical } \\
\text { Result Pass } \\
\text { RESRAD } \\
\text { Modeling? }\end{array}$} \\
\hline & & $\begin{array}{c}\text { Direct } \\
\text { Exposure }\end{array}$ & $\begin{array}{l}\text { Soil Cleanup } \\
\text { Level for } \\
\text { Groundwater } \\
\text { Protection }\end{array}$ & $\begin{array}{l}\text { Soil Cleanup } \\
\text { Level for } \\
\text { River } \\
\text { Protection }\end{array}$ & & \\
\hline Arsenic & $5.0(<\mathrm{BG})$ & 20 & 20 & 20 & No & -- \\
\hline Barium & $86.9(<\mathrm{BG})$ & $5,600^{b}$ & $132^{\mathrm{c}, \mathrm{d}}$ & $224^{\mathrm{e}}$ & No & - \\
\hline Beryllium & $0.17(<\mathrm{BG})$ & $10.4^{\mathrm{f}}$ & $1.51^{\mathrm{c}}$ & $1.51^{\mathrm{c}}$ & No & - \\
\hline Boron $^{\mathrm{g}}$ & 2.7 & 16,000 & 320 & $--^{h}$ & No & - \\
\hline Cadmium $^{\mathrm{i}}$ & $0.66(<\mathrm{BG})$ & 13.9 & $0.81^{\mathrm{c}}$ & $0.81^{\mathrm{c}}$ & No & - \\
\hline Chromium (total) & $9.3(<\mathrm{BG})$ & $80,000^{b}$ & $18.5^{\mathrm{c}}$ & $18.5^{\mathrm{c}}$ & No & - \\
\hline $\begin{array}{l}\text { Chromium } \\
\text { (hexavalent) }\end{array}$ & 0.31 & 2.1 & $4.8^{j}$ & 2 & No & -- \\
\hline Cobalt & $4.5(<\mathrm{BG})$ & 1,600 & 32 & $--^{h}$ & No & - \\
\hline Copper & $13.9(<\mathrm{BG})$ & 2,960 & 59.2 & $22^{\mathrm{c}}$ & No & -- \\
\hline Lead & 13.0 & 353 & $10.2^{c}$ & $10.2^{c}$ & Yes & Yes $^{k}$ \\
\hline Manganese & $230(<\mathrm{BG})$ & 11,200 & $512^{c}$ & $-{ }^{h}$ & No & - \\
\hline Nickel & $10.0(<\mathrm{BG})$ & 1,600 & $19.1^{c}$ & 27.4 & No & -- \\
\hline Vanadium & $33.6(<\mathrm{BG})$ & 560 & $85.1^{c}$ & $--^{h}$ & No & -- \\
\hline Zinc & $47.2(<\mathrm{BG})$ & 24,000 & 480 & $67.8^{c}$ & No & - \\
\hline Benzo(a)anthracene & 0.13 & $1.37^{l}$ & $0.33^{\mathrm{m}}$ & $0.33^{\mathrm{m}}$ & No & - \\
\hline Benzo(a)pyrene & 0.15 & $0.33^{\mathrm{m}}$ & $0.33^{\mathrm{m}}$ & $0.33^{\mathrm{m}}$ & No & - \\
\hline Benzo(b)fluoranthene & 0.15 & $1.37^{1}$ & $0.33^{\mathrm{m}}$ & $0.33^{\mathrm{m}}$ & No & - \\
\hline Benzo(g,h,i)perylene ${ }^{n}$ & 0.028 & 2,400 & 48 & 192 & No & -- \\
\hline Benzo(k)fluoranthene & 0.13 & $13.7^{1}$ & $0.33^{\mathrm{m}}$ & $0.33^{\mathrm{m}}$ & No & - \\
\hline Chrysene & 0.11 & $137^{\mathrm{i}}$ & $1.2^{1}$ & $0.33^{\mathrm{m}}$ & No & - \\
\hline Fluoranthene & 0.17 & 3,200 & 64 & 18 & No & - \\
\hline $\begin{array}{l}\text { Indeno }(1,2,3-\mathrm{cd}) \\
\text { pyrene }\end{array}$ & 0.025 & $1.37^{\mathrm{j}}$ & $0.33^{\mathrm{m}}$ & $0.33^{\mathrm{m}}$ & No & -- \\
\hline Phenanthrene $^{\mathrm{n}}$ & 0.034 & 24,000 & 240 & 1,920 & No & -- \\
\hline
\end{tabular}




\section{Table 5a. Comparison of Statistical Residual Contaminant Concentrations to Remedial Action Goals for the 100-F-31 Waste Site Excavated Area (Phase I).}

\begin{tabular}{|c|c|c|c|c|c|c|}
\hline \multirow[b]{2}{*}{$\mathrm{COC} / \mathrm{COPC}$} & \multirow[b]{2}{*}{$\begin{array}{c}\text { Statistical } \\
\text { Result } \\
\text { (mg/kg) }\end{array}$} & \multicolumn{3}{|c|}{ Remedial Action Goals ${ }^{\mathrm{a}}$ (mg/kg) } & \multirow{2}{*}{$\begin{array}{c}\text { Does the } \\
\text { Statistical } \\
\text { Result } \\
\text { Exceed } \\
\text { RAGs? }\end{array}$} & \multirow{2}{*}{$\begin{array}{l}\text { Does the } \\
\text { Statistical } \\
\text { Result Pass } \\
\text { RESRAD } \\
\text { Modeling? }\end{array}$} \\
\hline & & $\begin{array}{c}\text { Direct } \\
\text { Exposure }\end{array}$ & $\begin{array}{l}\text { Soil Cleanup } \\
\text { Level for } \\
\text { Groundwater } \\
\text { Protection }\end{array}$ & $\begin{array}{l}\text { Soil Cleanup } \\
\text { Level for } \\
\text { River } \\
\text { Protection }\end{array}$ & & \\
\hline Pyrene & 0.18 & 2,400 & 48 & 192 & No & -- \\
\hline
\end{tabular}

${ }^{\text {a }}$ Lookup values and RAGs obtained from the 100 Area RDR/RAWP (DOE-RL 2005b) or calculated per WAC 173-340-720, WAC 173-340-730, and WAC 173-340-740, Method B, 1996, unless otherwise noted.

b Noncarcinogenic cleanup level calculated from WAC 173-340-740(3), 1996 (Method B for soils) (as presented in the 100 Area RDR/RAWP [DOE-RL 2005b]). Updated oral reference dose values (as provided in IRIS) yield Method B direct exposure RAG values of $16,000 \mathrm{mg} / \mathrm{kg}$ and $120,000 \mathrm{mg} / \mathrm{kg}$ for barium and chromium, respectively.

c Where cleanup levels are less than background, cleanup levels default to background (WAC 173-340-700[4][d]) (1996).

d Barium soil cleanup level for groundwater protection calculated from WAC 173-340-740(3)(a)(ii)(A), 1996 ("100 times rule") and WAC 173-340-720(3), 1996 (Method B for groundwater) is $112 \mathrm{mg} / \mathrm{kg}$ (as presented in the 100 Area RDR/RAWP [DOE-RL $2005 \mathrm{~b}]$ ). The updated oral reference dose value (as provided in IRIS) yields a Method B groundwater cleanup criteria of $7 \mathrm{mg} / \mathrm{L}$, as compared to the more restrictive MCL of $2 \mathrm{mg} / \mathrm{L}$ (40 CFR 141). Per WAC 173-340-740(3)(a)(ii)(A), 1996 ("100 times rule"), the most restrictive updated soil cleanup level for groundwater protection would be $200 \mathrm{mg} / \mathrm{kg}$.

e Barium soil cleanup level for river protection calculated from WAC 173-340-740(3)(a)(ii)(A), 1996 ("100 times rule"), a dilution attenuation factor of 2, and WAC 173-340-720(3), 1996 (Method B for groundwater) is $224 \mathrm{mg} / \mathrm{kg}$ (as presented in the 100 Area RDR/RAWP [DOE-RL 2005b]). No surface water bioconcentration factor is available for barium and no ambient water quality criteria value exists separate from the previous drinking water standard; therefore, no WAC 173-340-730(3), 1996 (Method B for surface waters) value can be determined.

f Carcinogenic cleanup level calculated based on the inhalation exposure pathway per WAC 173-340-750[3], 1996 (Method B for air quality) and an airborne particulate mass loading rate of $0.0001 \mathrm{~g} / \mathrm{m}^{3}$ (WDOH 1997).

g No Hanford Site-specific or Washington State background value available.

h No cleanup level is available from the Ecology Cleanup Levels and Risk Calculations database (Ecology 2005), and no bioconcentration factor or ambient water quality criteria values are available to calculate cleanup levels (WAC 173-340-730(3)(a)(iii), 1996 [Method B for surface waters]).

i Hanford Site-specific background value is not available; not evaluated during background study. Value used is from Natural Background Soil Metals Concentrations in Washington State (Ecology 1994).

j Calculated cleanup level (per WAC 173-340-720(3), 1996 [Method B for groundwater] and WAC 173-340-740(3)(a)(ii)(A), 1996 ["100 times rule"]) presented is lower than that presented in the 100 Area RDR/RAWP (DOE-RL 2005b), based on updated oral reference dose value (as provided in IRIS).

k Based on 100 Area Analogous Sites RESRAD Calculations (BHI 2005), with a groundwater table elevation of $113 \mathrm{~m}$ (370 ft) and a clean zone extending from groundwater to an elevation of $123 \mathrm{~m}(404 \mathrm{ft})$.

1 Value listed in the 100 Area RDR/RAWP (DOE-RL 2005b) is based on the use of benzo(a)pyrene as a surrogate. Compoundspecific carcinogenic cleanup level calculated per WAC 173-340-740(3), 1996 (Method B for soils) using the ORNL oral cancer potency factor.

$m$ Where cleanup levels are less than the RDL, cleanup levels default to the RDL (WAC 173-340-707[2] 1996, and DOE-RL 2005b). Listed RDL values are based on EPA Method 8270 (semivolatile organic analysis); RDL values presented in the RDR/RAWP for these analytes are based on EPA Method 8310 (polyaromatic hydrocarbon-specific analysis).

$n$ Toxicity data for this chemical are not available. Cleanup levels are based on surrogate chemicals: Contaminant: benzo(g,h,i)perylene; surrogate: pyrene Contaminant: phenathrene; surrogate: anthracene.

-- $\quad=$ not applicable

$\mathrm{BG}$

$\mathrm{COC}=$ contaminant of concern

$\mathrm{COPC}=$ contaminant of potential concern

EPA = Environmental Protection Agencey

IRIS = Integrated Risk Information System

$\mathrm{MCL}=$ maximum contaminant level

$$
\begin{array}{ll}
\text { PAH } & =\text { polycyclic aromatic hydrocarbon } \\
\text { RAG } & =\text { remedial action goal } \\
\text { RESRAD } & \text { RESidual RADioactivity (dose assessment model) } \\
\text { RDR/RAWP } & =\text { remedial design report/remedial action work plan } \\
\text { RDL } & =\text { required detection limit } \\
\text { WAC } & =\text { Washington Administrative Code }
\end{array}
$$$$
\text { ORNL = Oak Ridge National Laboratory }
$$ 
Table 5b. Comparison of Statistical Residual Contaminant Concentrations to Remedial Action Goals for the 100-F-31 Waste Site Excavated Area (Phase II).

\begin{tabular}{|c|c|c|c|c|c|c|}
\hline \multirow{2}{*}{$\begin{array}{c}\text { Contaminant of } \\
\text { Concern }\end{array}$} & $\begin{array}{c}\text { Statistical } \\
\text { Result } \\
(\mathrm{mg} / \mathrm{kg})\end{array}$ & $\begin{array}{c}\text { Remedial Action Goals }(\mathrm{mg} / \mathrm{kg}) \\
\text { Exposure }\end{array}$ & $\begin{array}{c}\text { Soil Cleanup } \\
\text { Level for } \\
\text { Groundwater } \\
\text { Protection }\end{array}$ & $\begin{array}{c}\text { Revel for River } \\
\text { Protection }\end{array}$ & $\begin{array}{c}\text { Does the } \\
\text { Maximum } \\
\text { Result } \\
\text { Exceed } \\
\text { RAGs? }\end{array}$ & $\begin{array}{c}\text { Does the } \\
\text { Maximum } \\
\text { Result Pass } \\
\text { Modeling? }\end{array}$ \\
\hline Aroclor-1254 & 0.016 & 0.5 & $0.017^{\mathrm{b}}$ & $0.017^{\mathrm{b}}$ & No & -- \\
\hline
\end{tabular}

${ }^{a}$ Lookup values and RAGs obtained from the 100 Area RDR/RAWP (DOE-RL 2005b) or calculated per WAC 173-340-720, WAC 173-340-730, and WAC 173-340-740, Method B, 1996, unless otherwise noted.

b Where cleanup levels are less than the RDL, cleanup levels default to the RDL (WAC 173-340-707[2], 1996 and DOE-RL 2005b).

-- $\quad=$ not applicable

RAG = remedial action goal

$\mathrm{RDL} \quad=$ required detection limit

$\mathrm{RDR} / \mathrm{RAWP}=$ remedial design report/remedial action work plan

$\mathrm{WAC}=$ Washington Administrative Code

\section{DATA EVALUATION}

The statistical concentration of lead was determined to exceed soil RAGs for the protection of groundwater and the Columbia River within the 100-F-31 site remediation footprint. Data were not collected on the vertical extent of residual contamination but, given the soil-partitioning coefficient of lead $(30 \mathrm{~mL} / \mathrm{g})$, this contaminant would not be expected to migrate more than $3 \mathrm{~m}$ (10 ft) vertically in 1,000 years (BHI 2005). The vadose zone beneath the 100-F-31 excavation is approximately $10 \mathrm{~m}(33 \mathrm{ft})$ thick. Therefore, residual concentrations of lead at the $100-\mathrm{F}-31$ waste site are protective of groundwater. The only pathway for contamination to reach the Columbia River is via groundwater migration, so the lead contaminant concentration is also protective of river water.

Nonradionuclide risk requirements include a hazard quotient of less than 1.0 for all individual noncarcinogens, a cumulative hazard quotient of less than 1.0, an individual contaminant carcinogenic risk of less than $1 \times 10^{-6}$, and a cumulative excess carcinogenic risk of less than $1 \times 10^{-5}$. Risk values were not calculated for constituents that were not detected or were detected at concentrations below Hanford Site or Washington State background values. All individual hazard quotients were less than 1.0, and all individual cumulative excess carcinogenic risk values were less than $1 \times 10^{-6}$ (Appendix $\mathrm{C}$ ). The cumulative hazard quotient for the $100-\mathrm{F}-31$ waste site is $4.8 \times 10^{-2}$, and the cumulative excess carcinogenic risk value is $1.5 \times 10^{-6}$. Therefore, nonradionuclide risk requirements are met.

When using a statistical sampling approach, a RAG requirement for nonradionuclides is the WAC 173-340-740(7)(e) three-part test. The application of the three-part test for the 100-F-31 remediation footprint is included in statistical calculations (Appendix B). All residual $\mathrm{COC} / \mathrm{COPC}$ concentrations for the 100-F-31 remediation footprint pass the three-part test in comparison against direct exposure RAGs. Residual concentrations of lead fail the three-part test in comparison against soil RAGs for the protection of groundwater and the Columbia River. 
However, as described above, lead is not predicted to reach groundwater (and, thus, the river) within 1,000 years. Residual concentrations are, therefore, protective of groundwater and the Columbia River.

\section{DATA QUALITY ASSESSMENT}

\section{Confirmatory Sampling Data Quality Assessment}

Confirmatory samples were analyzed using analytical methods approved by the EPA. A data quality assessment (DQA) review was performed to compare the confirmatory sampling approach and resulting analytical data with the sampling and data requirements specified by the project objectives and performance specifications. This review involves evaluation of the data to determine if they are of the right type, quality, and quantity to support the intended use (i.e., closeout decisions). This assessment review completes the data life cycle (i.e., planning, implementation, and assessment) that was initiated by the data quality objectives process.

This DQA review was performed in accordance with ENV-1, Environmental Monitoring \& Management and based on the guidelines presented in Guidance for Data Quality Assessment (EPA 2000). Specific data quality objectives for the site are found in the SAP (DOE-RL 2005a). All samples were collected per the sample design (BHI 2004b). The sample design allowed for additional samples if required to properly characterize the site. Two additional samples were collected, mastic sealant and gray stained soil, and analyzed. The data quality requirements in the SAP were used for assessing data from statistical sampling and do not specifically apply to the data sets resulting from the focused sampling performed for the remaining sites. However, to ensure quality data sets, the SAP data quality assurance requirements, as well as the data validation procedures for chemical and radiochemical analysis (BHI 2000a, 2000b), were followed where appropriate.

The semivolatile organic compound (SVOC) analyses had high concentrations of some analytes and elevated the method detection limits of nondetected analytes above the required detection limits (RDLs) when the samples were diluted. The analyte pentachlorophenol had no recovery in the laboratory control sample [LCS]. There were issues with the surrogates in sample J01Y93 and the method blank. Therefore, SVOCs were retained as COPCs for verification sampling.

The PCB and PAH analyses had high analyte concentrations that initiated dilutions that drove the method detection limits of nondetected species above their RDLs. Because of high concentrations of these analytical groups, PCBs and most PAHs were retained as COPCs for verification sampling.

In the metals analyses, the extracts required 500-fold dilutions to allow the analyte mercury to be quantitated. Other problems with the analyses did not concern COPCs. Therefore, mercury was retained as a COPC for verification sampling. 
Limited, random, or sample matrix-specific-influenced batch quality control issues such as these are a potential for any analysis. The number and types seen in these data sets were within expectations for the matrix types and analyses performed.

The DQA review for confirmatory sampling for the 100-F-31 site found the results to be accurate within the standard errors associated with the methods, including sampling and sample handling and concluded that the data are of the right type, quality, and quantity to support the intended use, except as noted above. Detection limits, precision, accuracy, and sampling data group completeness were assessed to determine if any analytical results should be rejected as a result of quality assurance and quality control deficiencies. All analytical data were found to be acceptable for decision-making purposes. The confirmatory sample analytical data are stored in the ENRE project-specific database prior to archiving in HEIS and are summarized in Appendix A.

\section{Verification Sampling Data Quality Assessment}

A DQA was performed to compare the sampling approach and analytical data with the sampling and data requirements specified in the site-specific work instruction (WCH 2005a). This DQA was performed in accordance with procedures detailed in ENV-1, Environmental Monitoring \& Management and based on guidelines present in EPA (2000). Specific data quality objectives for the site are found in the SAP (DOE-RL 2005a). A review of the work instruction (WCH 2005), the field logbooks (WCH 2006b, 2006c), and applicable analytical data packages has been performed as part of this DQA. To ensure quality data, the SAP data assurance requirements and the data validation procedures for chemical and radiochemical analysis (BHI 2000a, 2000b) are used as appropriate. This review involves evaluation of the data to determine if they are of the right type, quality, and quantity to support the intended use (i.e., closeout decisions). The DQA completes the data life cycle (i.e., planning, implementation, and assessment) that was initiated by the data quality objectives process.

Data from verification samples collected at the 100-F-31 site were provided by the laboratory in sample delivery group SDG K0211 and K0368. No major deficiencies were found in the data, and all of the data were found to be useable for decision-making purposes. Minor deficiencies are presented in the descriptions of the SDGs and analyses below.

\section{SDG K0211: Phase I Sampling Results}

SDG K0211 consists of 12 samples (J112D3 through J112D9 and J112F0 through J112F4). Sample J112F4 is the field equipment blank, which was analyzed for inductively coupled plasma (ICP) metals, mercury, and SVOCs. Sample J112F3 is a field duplicate of sample J112D3. The field duplicate and the remaining field samples were analyzed for SVOCs, PCBs, metals by ICP analysis, mercury, hexavalent chromium, and by gamma energy analysis (GEA). Third-party validation of SDG K0211 is presented along with the following comments. 


\section{$\underline{\text { Semivolatile Organic Analysis }}$}

The common laboratory contaminants bis-(2-ethylhexyl)phthalate and di-n-butylphthalate were found in the method blank at concentrations below the contract RDL. Third-party validation raised all of the detected results in SDG K0211 to the RDL and requalified those results as nondetected with "U" flags. The matrix spike (MS) and matrix spike duplicate were below the acceptance criteria for the analyte 1,2,4-trichlorobenzene at 55\% and 56\%, respectively. Thirdparty validation qualified all results in SDG K0211 for 1,2,4-trichlorobenzene as estimates with "J" flags. The LCS was below the acceptance criteria for the analytes 2,4-dimethylphenol and trichlorobenzene at $47 \%$ and $56 \%$, respectively. Third-party validation qualified all results in SDG K0211 for 2,4-dimethylphenol as estimates with "J" flags.

\section{$\underline{\text { ICP Metals and Mercury }}$}

The laboratory had difficulty with a continuing calibration verification sample run after the field samples. The samples were analyzed a second time; however, several high concentration analytes forced the samples to be diluted. As such, these samples were analyzed during a third run. The analytes arsenic, selenium, and antimony were quantified from the first run. The analytes aluminum, beryllium, potassium, manganese, and sodium were quantitated from the third run. The remaining analytes were quantitated from the second run. The laboratory made this decision to provide the best possible data from these three runs.

Method blank contamination was observed for arsenic, cadmium, and sodium. Third-party validation qualified the arsenic results in samples J112D4, J112D6, J112D8, J112D9, J112F3, and J112F4 as nondetected estimates with "UJ" flags. The cadmium results in samples J112D3, $\mathrm{J} 112 \mathrm{D} 6$, and $\mathrm{J} 112 \mathrm{~F} 4$, as well as the sodium results in sample $\mathrm{J} 112 \mathrm{~F} 4$, were also all qualified as nondetected estimates. The method blank contaminations are not significant at the levels observed.

The LCS recovery for silicon was below the acceptance criteria ( $70 \%$ to $130 \%)$ at $67.8 \%$. Thirdparty validation qualified all of the silicon results in SDG K0211 as estimated with "J" flags. The MS recovery for antimony was below the acceptance criteria (70\% to $130 \%)$ at $59.9 \%$. Third-party validation qualified all of the antimony results in SDG K0211 as estimated with "J" flags.

The MS recoveries for aluminum, iron, and manganese did not meet the laboratories acceptance criteria. The laboratory performed serial dilutions and post digestion spikes for these analytes with good results. Third-party validation did not qualify the aluminum, iron, or manganese results.

\section{$\underline{\mathrm{PCBS}}$}

The MS recovery for aroclor- 1260 was above the acceptance criteria at $142 \%$. Third-party validation qualified all detected PCB results, except for aroclor-1016, as estimates with "J" flags. The aroclor-1016 results were not qualified because the specific recovery for aroclor-1016 was within the acceptance criteria. 


\section{$\underline{\text { GEA }}$}

The laboratory duplicate relative percent difference for thorium-232 was above the acceptance criteria $(<30 \%)$ at $45 \%$. This was most likely caused by natural heterogeneity within the sample matrix. Third-party validation qualified all of the thorium-232 data in SDG K0211 as estimates with "J" flags.

\section{SDG K0368: Phase II Sampling Results}

SDG K0368 consists of 11 samples (J12670 through J12680). Sample J12674 is a field duplicate of sample J12673. The field duplicate and field samples were analyzed for PCBs. There were no issues with the PCB data.

\section{Conclusions}

Limited, random, or sample matrix-specific influenced batch quality control issues such as these are a potential for any analysis. The number and types seen in these data sets were within expectations for the matrix types and analyses performed. The DQA review of the verification data for the 100-F-31 site found the results to be accurate within the standard errors associated with the methods, including sampling and sample handling. This DQA review for the 100-F-31 site concludes that the 100-F-31 verification data reviewed are of the right type, quality, and quantity to support the intended use. Detection limits, precision, accuracy, and sampling data group completeness were assessed to determine if any analytical results should be rejected as a result of quality assurance and quality control deficiencies. All analytical data were found acceptable for decision-making purposes. The verification sample analytical data are stored in the ENRE project-specific database prior to archiving in HEIS and are summarized in Appendix B.

\section{SUMMARY FOR INTERIM CLOSURE}

The 100-F-31, 144-F Sanitary Sewer System waste site has been evaluated and remediated in accordance with the Remaining Sites ROD (EPA 1999) and the RDR/RAWP (DOE-RL 2005b). Because concentrations of PAHs, aroclor-1254, mercury, and hexavalent chromium were found during confirmatory sampling at levels in exceedance of the RAGs, approximately 350 bank cubic meters (460 bank cubic yards) of material was removed for disposal at the Environmental Restoration Disposal Facility. Statistical sampling to verify the completeness of remediation was performed, and analytical results were shown to meet the cleanup objectives for direct exposure, groundwater protection, and river protection. In accordance with this evaluation, the verification sampling results support a reclassification of the 100-F-31 site to interim closed out. This site does not have a deep zone; therefore, no deep zone institutional controls are required. 


\section{REFERENCES}

40 CFR 141, "National Primary Drinking Water Regulations," Code of Federal Regulations, as amended.

Bergstrom, K. A., T. H. Mitchell, and J. J. Sharpe, 2004, Results of Geophysical Investigation at 100-F Area Remaining Sites, CCN 112477, Interoffice Memorandum to R. A. Carlson and S. W. Callison, dated May 27, 2004, Bechtel Hanford, Inc., Richland, Washington.

BHI, 2000a, Data Validation Procedure for Chemical Analysis, BHI-01435, Rev. 0, Bechtel Hanford, Inc., Richland, Washington.

BHI, 2000b, Data Validation Procedure for Radiochemical Analysis, BHI-01433, Rev. 0, Bechtel Hanford, Inc., Richland, Washington.

BHI, 2001, Calculation of Total Uranium Activity Corresponding to a Maximum Contaminant Level for Total Uranium of 30 Micrograms per Liter in Groundwater, 0100X-CA-V0038, Rev. 0, Bechtel Hanford, Inc., Richland, Washington.

BHI, 2004a, Remaining Sites Field Sampling, Logbook EL-1578-3, Bechtel Hanford, Inc., Richland, Washington.

BHI, 2004b, Work Instruction for 100-F-31 Septic System (144-F Sanitary Sewer System), 0100F-WI-G0014, Rev. 0, Bechtel Hanford, Inc., Richland, Washington.

BHI, 2005, 100 Area Analogous Sites RESRAD Calculations, 0100X-CA-V0050, Rev. 0, Bechtel Hanford, Inc., Richland, Washington.

DOE Order 5400.5, Radiation Protection of the Public and Environment, as amended, U.S. Department of Energy, Washington, D.C.

DOE-RL, 1998, Tri-Party Agreement Handbook Management Procedures, RL-TPA-90-0001, Guideline Number TPA-MP-14, "Maintenance of the Waste Information Data System (WIDS)," U.S. Department of Energy, Richland Operations Office, Richland, Washington.

DOE-RL, 2005a, 100 Area Remedial Action Sampling and Analysis Plan, DOE/RL-96-22, Rev. 4, U.S. Department of Energy, Richland Operations Office, Richland, Washington.

DOE-RL, 2005b, Remedial Design Report/Remedial Action Work Plan for the 100 Area, DOE/RL-96-17, Rev. 5, U.S. Department of Energy, Richland Operations Office, Richland, Washington.

Ecology, 1994, Natural Background Soil Metals Concentrations in Washington State, Publication No. 94-115, Washington State Department of Ecology, Olympia, Washington. 
Ecology, 1995, Guidance on Sampling and Data Analysis Methods, Publication No. 94-49, Washington State Department of Ecology, Olympia, Washington.

Ecology, 2005, Cleanup Levels and Risk Calculations (CLARC) Database, Washington State Department of Ecology, Olympia, Washington, $<$ https://fortress.wa.gov/ecy/clarc.CLARCHome.aspx>.

ENV-1, Environmental Monitoring \& Management, Washington Closure Hanford, Richland, Washington.

EPA, 1999, Interim Action Record of Decision for the 100-BC-1, 100-BC-2, 100-DR-1, 100-DR-2, 100-FR-1, 100-FR-2, 100-HR-1, 100-HR-2, 100-KR-1, 100-KR-2, 100-IU-2, 100-IU-6, and 200-CW-3 Operable Units, Hanford Site, Benton County, Washington, U.S. Environmental Protection Agency, Region 10, Seattle, Washington.

EPA, 2000, Guidance for Data Quality Assessment: Practical Methods for Data Analysis, EPA/600/R-96/084, U.S. Environmental Protection Agency, Washington, D.C.

Feist, E. T., 2005, 100-F-31 Remaining Site for Remedial Action, Interoffice Memorandum to R. A. Carlson, CCN 118817, dated January 26, 2005, Bechtel Hanford, Inc., Richland, Washington.

GE, 1963, "Plumbing \& Details - Facilities for Radioactive Inhalation Studies," Drawing H-1-14123, General Electric Company, Richland, Washington.

Gilbert, R. O., 1987, Statistical Methods for Environmental Pollution Monitoring, Wiley \& Sons, Inc., New York, New York.

WAC 173-340, 1996, "Model Toxics Control Act -- Cleanup," Washington Administrative Code.

WCH, 2005, Verification Work Instruction for the 100-F-31 Septic System, 144-F Sanitary Sewer System, 0100F-WI-G0035, Rev. 0, Washington Closure Hanford, Richland, Washington.

WCH, 2006a, "100-F Field Remediation Cleanup Verification," Meeting Minutes to Distribution from S. W. Callison, CCN 127646, dated May 10, 2006, Washington Closure Hanford, Richland, Washington.

WCH, 2006b, Remaining Site Field Sampling, Logbook EFL-1174, pp. 82-87, Washington Closure Hanford, Richland, Washington.

WCH, 2006c, Remaining Site Field Sampling, Logbook EFL-1174-1, pp. 45-47, Washington Closure Hanford, Richland, Washington. 
WDOH, 1997, State of Washington Department of Health Interim Regulatory Guidance: Hanford Guidance for Radiological Cleanup, WDOH/320-015, Rev. 1, Washington Department of Health, Olympia, Washington.

WHC, 1991, Summary of the Hanford Site Decontamination, Decommissioning, and Cleanup FY 1974 Through FY 1990, WHC-EP-0478, Westinghouse Hanford Company, Richland, Washington.

WHC, 1993, 100-F Reactor Site Technical Baseline Report Including Operable Units 100-FR-1 and 100-FR-2, WHC-SD-EN-TI-169, Rev. 0, Westinghouse Hanford Company, Richland, Washington. 


\section{APPENDIX A \\ CONFIRMATORY AND WASTE CHARACTERIZATION SAMPLING RESULTS}

Note: This appendix contains the sample results that lead to a decision that remediation was necessary. Verification sampling results, to support site closeout, are provided in Appendix B. 
Table A-1. 100-F-31 Confirmatory Sampling Results. (5 Pages)

\begin{tabular}{|c|c|c|c|c|c|c|c|c|c|c|c|c|c|c|c|c|c|c|c|c|}
\hline \multirow{2}{*}{ Sample Location } & \multirow{2}{*}{$\begin{array}{c}\text { HEIS } \\
\text { Number }\end{array}$} & \multirow{2}{*}{$\begin{array}{c}\text { Sample } \\
\text { Date }\end{array}$} & \multicolumn{3}{|c|}{ Americium-241 GEA } & \multicolumn{3}{|c|}{ Cesium-137 } & \multicolumn{3}{|c|}{ Cobalt-60 } & \multicolumn{3}{|c|}{ Europium-152 } & \multicolumn{3}{|c|}{ Europium-154 } & \multicolumn{3}{|c|}{ Europium-155 } \\
\hline & & & $\mathrm{pCi} / \mathrm{g}$ & 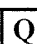 & MDA & $\mathrm{pCi} / \mathrm{g}$ & $Q$ & MDA & $\mathrm{pCi} / \mathrm{g}$ & $Q$ & $\overline{\text { MDA }}$ & $\mathrm{pCi} / \mathrm{g}$ & $Q$ & $\overline{\text { MDA }}$ & $\mathrm{pCi} / \mathrm{g}$ & $Q$ & MDA & $\mathrm{pCi} / \mathrm{g}$ & 0 & $\overline{\mathrm{MDA}}$ \\
\hline Septic Tank & J01Y91 & $10 / 15 / 04$ & 0.294 & & 0.29 & 0.186 & & 0.055 & 0 & $\overrightarrow{\mathrm{U}}$ & 0.044 & 0 & $\bar{U}$ & 0.12 & 0 & $\overrightarrow{\mathrm{U}}$ & 0.14 & 0 & $\mathrm{U}$ & 0.12 \\
\hline Duplicate of J01Y91 & J01Y92 & $10 / 15 / 04$ & 0.554 & & 0.3 & 0 & $\mathrm{U}$ & 0.18 & 0 & $\mathrm{U}$ & 0.13 & 0 & $\mathrm{U}$ & 0.32 & 0 & $\mathrm{U}$ & 0.39 & 0 & $\mathrm{U}$ & 0.31 \\
\hline
\end{tabular}

\begin{tabular}{|c|c|c|c|c|c|c|c|c|c|c|c|c|c|c|c|c|c|c|c|c|}
\hline \multirow{2}{*}{ Sample Location } & \multirow{2}{*}{$\begin{array}{c}\text { HEIS } \\
\text { Number }\end{array}$} & \multirow{2}{*}{\begin{tabular}{|c|} 
Sample \\
Date \\
\end{tabular}} & \multicolumn{3}{|c|}{ Gross alpha } & \multicolumn{3}{|c|}{ Gross beta } & \multicolumn{3}{|c|}{ Potassium-40 } & \multicolumn{3}{|c|}{ Radium-226 } & \multicolumn{3}{|c|}{ Radium-228 } & \multicolumn{3}{|c|}{ Thorium-228 GEA } \\
\hline & & & $\mathrm{pCi} / \mathrm{g}$ & $Q$ & MDA & $\mathrm{pCi} / \mathrm{g}$ & $Q$ & MDA & $\mathrm{pCi} / \mathrm{g}$ & $Q$ & MDA & $\mathrm{pCi} / \mathrm{g}$ & $Q$ & MDA & $\mathrm{pCi} / \mathrm{g}$ & $Q$ & MDA & $\mathrm{pCi} / \mathrm{g}$ & $Q$ & MDA \\
\hline Septic Tank & J01Y91 & $10 / 15 / 04$ & 16.8 & & 2.9 & 7.02 & & 6.8 & 2.96 & & 0.48 & 0.369 & & 0.091 & 0.212 & & 0.2 & 0.16 & & 0.05 \\
\hline Duplicate of J01Y91 & J01Y92 & $10 / 15 / 04$ & 13.6 & & 4 & 10.2 & & 5.9 & 0 & U & 3.3 & 0.431 & & 0.23 & 0 & $\mathrm{U}$ & 0.51 & 0.321 & & 0.23 \\
\hline
\end{tabular}

\begin{tabular}{|c|c|c|c|c|c|c|c|c|c|c|c|}
\hline \multirow{2}{*}{ Sample Location } & \multirow{2}{*}{$\begin{array}{c}\text { HEIS } \\
\text { Number }\end{array}$} & \multirow{2}{*}{$\begin{array}{c}\text { Sample } \\
\text { Date }\end{array}$} & \multicolumn{3}{|c|}{ Thorium-232 GEA } & \multicolumn{3}{|c|}{ Uranium-235 GEA } & \multicolumn{3}{|c|}{ Uranium-238-GEA } \\
\hline & & & $\mathrm{pCi} / \mathrm{g}$ & $Q$ & MDA & $\mathrm{pCi} / \mathrm{g}$ & $\mathbf{Q}$ & MDA & $\mathrm{pCi} / \mathrm{g}$ & $Q$ & MDA \\
\hline Septic Tank & J01Y91 & $10 / 15 / 04$ & 0.212 & & 0.2 & 0 & $\mathrm{U}$ & 0.18 & 0 & $\mathrm{U}$ & 5.9 \\
\hline Duplicate of J01Y91 & J01Y92 & $10 / 15 / 04$ & 0 & $\mathrm{U}$ & 0.51 & 0 & $\mathrm{U}$ & 0.47 & 0 & $\mathrm{U}$ & 18 \\
\hline
\end{tabular}

Acronyms and notes apply to all of the tables in this appendix.

Note: Data qualified with B, C, and/or J, are considered acceptable values

$B=$ blank contamination (organic constituents)

$\mathrm{C}=$ blank contamination (inorganic constituents)

$\mathrm{D}=$ diluted

GEA = gamma energy analysis

HEIS $=$ Hanford Environmental Information System

$\mathrm{J}=$ estimated

$\mathrm{MDA}=$ minimum detectable activity

$\mathrm{PQL}=$ practical quantitation limit

$\mathrm{Q}=$ qualifier

$\mathrm{U}=$ undetected 
Table A-1. 100-F-31 Confirmatory Sampling Results. (5 Pages)

\begin{tabular}{|c|c|c|c|c|c|c|c|c|c|c|c|c|c|c|c|c|c|c|c|c|}
\hline \multirow{2}{*}{ Sample Location } & \multirow{2}{*}{$\begin{array}{c}\text { HEIS } \\
\text { Number }\end{array}$} & \multirow{2}{*}{$\begin{array}{c}\text { Sample } \\
\text { Date }\end{array}$} & \multicolumn{3}{|c|}{ Aluminum } & \multicolumn{3}{|c|}{ Antimony } & \multicolumn{3}{|c|}{ Arsenic } & \multicolumn{3}{|c|}{ Barium } & \multicolumn{3}{|c|}{ Beryllium } & \multicolumn{3}{|c|}{ Boron } \\
\hline & & & $\mathrm{mg} / \mathrm{kg}$ & $Q$ & PQL & $\mathrm{mg} / \mathrm{kg}$ & Q & PQL & $\mathrm{mg} / \mathrm{kg}$ & $Q$ & PQL & $\mathrm{mg} / \mathrm{kg}$ & Q & PQL & $\mathrm{mg} / \mathrm{kg}$ & $Q$ & PQL & $\mathrm{mg} / \mathrm{kg}$ & $Q$ & PQL \\
\hline Equipment Blank & J01Y93 & $10 / 15 / 04$ & 57.9 & $\mathrm{C}$ & 0.79 & 0.29 & U & 0.29 & 0.4 & & 0.35 & 1 & C & 0.02 & 0.05 & C & 0.01 & 0.5 & $\mathrm{U}$ & 0.5 \\
\hline Septic Tank & J01Y91 & $10 / 15 / 04$ & 7900 & $\mathrm{C}$ & 1.6 & 7.1 & & 0.58 & 10 & & 0.7 & 721 & C & 0.04 & 0.2 & C & 0.02 & 5.7 & & 0.99 \\
\hline Duplicate of J01Y91 & $\mathrm{J} 01 Y 92$ & $10 / 15 / 04$ & 7560 & $\mathrm{C}$ & 1.5 & 6.4 & & 0.56 & 9.3 & & 0.67 & 555 & $\mathrm{C}$ & 0.04 & 0.2 & $\mathrm{C}$ & 0.02 & 5.1 & & 0.95 \\
\hline Stain Soil & J01Y94 & $10 / 15 / 04$ & 5410 & $\mathrm{C}$ & 0.83 & 0.31 & $\mathrm{U}$ & 0.31 & 2 & & 0.37 & 145 & C & 0.02 & 0.41 & $\mathrm{C}$ & 0.01 & 10.2 & & 0.52 \\
\hline
\end{tabular}

\begin{tabular}{|c|c|c|c|c|c|c|c|c|c|c|c|c|c|c|c|c|c|c|c|c|}
\hline \multirow{2}{*}{ Sample Location } & \multirow{2}{*}{\begin{tabular}{|c|} 
HEIS \\
Number
\end{tabular}} & \multirow{2}{*}{\begin{tabular}{|c|}
$\begin{array}{c}\text { Sample } \\
\text { Date }\end{array}$ \\
\end{tabular}} & \multicolumn{3}{|c|}{ Cadmium } & \multicolumn{3}{|c|}{ Calcium } & \multicolumn{3}{|c|}{ Chromium } & \multicolumn{3}{|c|}{ Cobalt } & \multicolumn{3}{|c|}{ Copper } & \multicolumn{3}{|c|}{ Hexavalent Chromium } \\
\hline & & & $\mathrm{mg} / \mathrm{kg}$ & Q & PQL & $\mathrm{mg} / \mathrm{kg}$ & Q & $\mathrm{PQL}$ & $\mathrm{mg} / \mathrm{kg}$ & $Q$ & PQL & $\mathrm{mg} / \mathrm{kg}$ & $Q$ & $\mathrm{PQL}$ & $\mathrm{mg} / \mathrm{kg}$ & Q & PQL & $\mathrm{mg} / \mathrm{kg}$ & $Q$ & PQL \\
\hline Equipment Blank & J01Y93 & $10 / 15 / 04$ & 0.03 & $\mathrm{U}$ & 0.03 & 23.5 & C & 0.67 & 0.45 & $\mathrm{C}$ & 0.06 & 0.08 & $\mathrm{U}$ & 0.08 & 0.1 & & 0.05 & & & \\
\hline Septic Tank & J01Y91 & $10 / 15 / 04$ & 7.6 & & 0.06 & 9960 & $\mathrm{C}$ & 1.3 & 78.8 & $\mathrm{C}$ & 0.12 & 4 & & 0.15 & 475 & & 0.1 & & & \\
\hline Duplicate of J01Y91 & J01Y92 & $10 / 15 / 04$ & 8.1 & & 0.06 & 12100 & $\mathrm{C}$ & 1.3 & 88.8 & $\mathrm{C}$ & 0.11 & 4.4 & & 0.15 & 427 & & 0.09 & & & \\
\hline Septic Tank & J01Y97* & $10 / 15 / 04$ & & & & & & & & & & & & & & & & 204 & & 0.35 \\
\hline Septic Tank & J01Y96* & $10 / 15 / 04$ & & & & & & & & & & & & & & & & 214 & & 0.35 \\
\hline Stain Soil & J01Y94 & $10 / 15 / 04$ & 0.04 & & 0.03 & 5890 & C & 0.71 & 10.8 & C & 0.06 & 5.8 & & 0.08 & 16.2 & & 0.05 & & & \\
\hline
\end{tabular}

\begin{tabular}{|c|c|c|c|c|c|c|c|c|c|c|c|c|c|c|c|c|c|c|c|c|}
\hline \multirow{2}{*}{ Sample Location } & \multirow{2}{*}{$\begin{array}{c}\text { HEIS } \\
\text { Number }\end{array}$} & \multirow{2}{*}{\begin{tabular}{|c|}
$\begin{array}{c}\text { Sample } \\
\text { Date }\end{array}$ \\
\end{tabular}} & \multicolumn{3}{|c|}{ Iron } & \multicolumn{3}{|c|}{ Lead } & \multicolumn{3}{|c|}{ Magnesium } & \multicolumn{3}{|c|}{ Manganese } & \multicolumn{3}{|c|}{ Mercury } & \multicolumn{3}{|c|}{ Molybdenum } \\
\hline & & & $\mathrm{mg} / \mathrm{kg}$ & $Q$ & PQL & $\mathrm{mg} / \mathrm{kg}$ & Q & $\mathrm{PQL}$ & $\mathrm{mg} / \mathrm{kg}$ & $Q$ & PQL & $\mathrm{mg} / \mathrm{kg}$ & $Q$ & $\mathrm{PQL}$ & $\mathrm{mg} / \mathrm{kg}$ & Q & PQL & $\mathrm{mg} / \mathrm{kg}$ & $Q$ & PQL \\
\hline \begin{tabular}{|l} 
Equipment Blank \\
\end{tabular} & J01Y93 & $10 / 15 / 04$ & 488 & & 2.2 & 0.21 & & 0.18 & 8 & & 0.64 & 3.1 & C & 0.01 & 0.01 & $\mathrm{U}$ & 0.01 & 0.13 & $\mathrm{U}$ & 0.13 \\
\hline Septic Tank & J01Y91 & $10 / 15 / 04$ & 14600 & & 4.4 & 156 & & 0.37 & 2750 & & 1.3 & 116 & C & 0.02 & 870 & & 17.4 & 10.6 & & 0.25 \\
\hline Duplicate of J01Y91 & J01Y92 & $10 / 15 / 04$ & 14800 & & 4.2 & 164 & & 0.35 & 3180 & & 1.2 & 140 & C & 0.02 & 1110 & & 15.8 & 9.9 & & 0.24 \\
\hline Stain Soil & J01Y94 & $10 / 15 / 04$ & 16800 & & 2.3 & 10.9 & & 0.19 & 3420 & & 0.68 & 251 & C & 0.01 & 0.02 & & 0.01 & 0.45 & & 0.13 \\
\hline
\end{tabular}

\begin{tabular}{|c|c|c|c|c|c|c|c|c|c|c|c|c|c|c|c|c|c|c|c|c|}
\hline \multirow{2}{*}{ Sample Location } & \multirow{2}{*}{$\begin{array}{c}\text { HEIS } \\
\text { Number }\end{array}$} & \multirow{2}{*}{\begin{tabular}{|c|} 
Sample \\
Date \\
\end{tabular}} & \multicolumn{3}{|c|}{ Nickel } & \multicolumn{3}{|c|}{ Potassium } & \multicolumn{3}{|c|}{ Selenium } & \multicolumn{3}{|c|}{ Silicon } & \multicolumn{3}{|c|}{ Silver } & \multicolumn{3}{|c|}{ Sodium } \\
\hline & & & $\mathrm{mg} / \mathrm{kg}$ & $Q$ & PQL & $\mathrm{mg} / \mathrm{kg}$ & $Q$ & PQL & $\mathrm{mg} / \mathrm{kg}$ & $Q$ & PQL & $\mathrm{mg} / \mathrm{kg}$ & $\mathrm{Q}$ & PQL & $\mathrm{mg} / \mathrm{kg}$ & $Q$ & PQL & $\mathrm{mg} / \mathrm{kg}$ & $Q$ & PQL \\
\hline Equipment Blank & J01Y93 & $10 / 15 / 04$ & 0.12 & $\mathrm{U}$ & 0.12 & 21.7 & $\mathrm{C}$ & 3.4 & 0.38 & $\mathrm{U}$ & 0.38 & 45.4 & C & 0.49 & 0.09 & $\mathrm{U}$ & 0.09 & 12.8 & $\mathrm{C}$ & 0.22 \\
\hline Septic Tank & J01Y91 & $10 / 15 / 04$ & 45 & & 0.23 & 676 & $\mathrm{C}$ & 6.8 & 81.4 & & 0.76 & 627 & $\mathrm{C}$ & 0.97 & 5.3 & & 0.17 & 541 & $\mathrm{C}$ & 0.45 \\
\hline Duplicate of J01Y91 & J01Y92 & $10 / 15 / 04$ & 47.2 & & 0.22 & 701 & $\mathrm{C}$ & 6.5 & 71 & & 0.72 & 588 & $\mathrm{C}$ & 0.93 & 4.3 & & 0.17 & 564 & $\mathrm{C}$ & 0.43 \\
\hline Stain Soil & J01Y94 & $10 / 15 / 04$ & 10.3 & & 0.12 & 1200 & C & 3.6 & 0.4 & $\mathrm{U}$ & 0.4 & 372 & C & 0.51 & 0.09 & $\mathrm{U}$ & 0.09 & 244 & $\mathrm{C}$ & 0.24 \\
\hline
\end{tabular}

\begin{tabular}{|l|c|c|c|c|c|c|c|c|}
\hline \multirow{2}{*}{ Sample Location } & HEIS & Sample & \multicolumn{3}{|c|}{ Vanadium } & \multicolumn{3}{|c|}{ Zinc } \\
\cline { 5 - 8 } & Number & Date & $\mathbf{m g} / \mathbf{k g}$ & $\mathrm{Q}$ & $\mathbf{P Q L}$ & $\mathbf{m g} / \mathbf{k g}$ & $\mathbf{Q}$ & PQL \\
\hline Equipment Blank & J01Y93 & $10 / 15 / 04$ & 0.13 & & 0.06 & 1.7 & $\mathrm{C}$ & 0.04 \\
\hline Septic Tank & J01Y91 & $10 / 15 / 04$ & 45.3 & & 0.12 & 1600 & $\mathrm{C}$ & 0.08 \\
\hline Duplicate of J01Y91 & J01Y92 & $10 / 15 / 04$ & 43 & & 0.11 & 1570 & $\mathrm{C}$ & 0.07 \\
\hline Stain Soil & J01Y94 & $10 / 15 / 04$ & 46.6 & & 0.06 & 76.8 & $\mathrm{C}$ & 0.04 \\
\hline
\end{tabular}

*Only analyte was hexavalent chromium. 
Table A-1. 100-F-31 Confirmatory Sampling Results. (5 Pages)

\begin{tabular}{|c|c|c|c|c|c|c|c|c|c|c|c|c|c|c|c|}
\hline \multirow[t]{2}{*}{ Constituent } & \multicolumn{3}{|c|}{$\begin{array}{c}\text { J01 Y91 } \\
\text { Septic Tank } \\
\text { Sample Date } \\
\text { 10/15/04 }\end{array}$} & \multicolumn{3}{|c|}{$\begin{array}{c}\text { J01Y92 } \\
\text { Duplicate of J01Y91 } \\
\text { Sample Date } \\
\text { 10/15/04 }\end{array}$} & \multicolumn{3}{|c|}{$\begin{array}{c}\text { J01Y93 } \\
\text { Equipment Blank } \\
\text { Sample Date } \\
10 / 15 / 04\end{array}$} & \multicolumn{3}{|c|}{$\begin{array}{c}\text { J01Y94 } \\
\text { Stain Soil } \\
\text { Sample Date } \\
\text { 10/15/04 }\end{array}$} & \multicolumn{3}{|c|}{$\begin{array}{c}\text { J01Y95 } \\
\text { Mastic from Lid } \\
\text { Sample Date } 10 / 15 / 04\end{array}$} \\
\hline & $\mu \mathrm{g} / \mathrm{kg}$ & $Q$ & PQL & $\mu \mathrm{g} / \mathrm{kg}$ & Q & PQL & $\mu \mathrm{g} / \mathrm{kg}$ & $Q$ & PQL & $\mu \mathrm{g} / \mathrm{kg}$ & Q & PQL & $\mu \mathrm{g} / \mathrm{kg}$ & $Q$ & PQL \\
\hline \multicolumn{16}{|c|}{ PAHs (Polycyclic aromatic hydrocarbons) } \\
\hline Acenaphthene & 2090 & $\mathrm{U}$ & 2090 & 2150 & $\mathrm{U}$ & 2150 & 100 & $\mathrm{U}$ & 100 & 106 & $\mathrm{U}$ & 106 & 605000 & \begin{tabular}{|l|l}
$U$ \\
\end{tabular} & 605000 \\
\hline Acenaphthylene & 2090 & $\mathrm{U}$ & 2090 & 2150 & $\mathrm{U}$ & 2150 & 100 & $\mathrm{U}$ & 100 & 106 & $\mathrm{U}$ & 106 & 605000 & U & 605000 \\
\hline Anthracene & 190 & & 105 & 190 & & 108 & 5.01 & $\mathrm{U}$ & 5.01 & 9.8 & & 5.3 & 3200000 & & 30300 \\
\hline Benzo(a)anthracene & 1100 & & 105 & 1100 & & 108 & 5.01 & $\mathrm{U}$ & 5.01 & 130 & & 5.3 & 3500000 & & 30300 \\
\hline Benzo(a)pyrene & 1300 & & 105 & 1200 & & 108 & 5.01 & $\mathrm{U}$ & 5.01 & 130 & & 5.3 & 2100000 & & 30300 \\
\hline Benzo(b)fluoranthene & 2600 & & 105 & 2300 & & 108 & 5.01 & $\mathrm{U}$ & 5.01 & 220 & & 5.3 & 2500000 & & 30300 \\
\hline Benzo(ghi)perylene & 1000 & & 105 & 880 & & 108 & 5.01 & $\mathrm{U}$ & 5.01 & 79 & & 5.3 & 610000 & & 30300 \\
\hline Benzo(k)fluoranthene & 650 & & 105 & 570 & & 108 & 5.01 & $\mathrm{U}$ & 5.01 & 67 & & 5.3 & 1200000 & & 30300 \\
\hline Chrysene & 1100 & & 105 & 1500 & & 108 & 5.01 & $\mathrm{U}$ & 5.01 & 180 & & 5.3 & 3100000 & & 30300 \\
\hline Dibenz $[\mathrm{a}, \mathrm{h}]$ anthracene & 210 & & 105 & 170 & & 108 & 5.01 & $\mathrm{U}$ & 5.01 & 16 & & 5.3 & 150000 & & 30300 \\
\hline Fluoranthene & 3600 & & 210 & 3100 & & 216 & 10 & $\mathrm{U}$ & 10 & 470 & & 10.6 & 15000000 & & 60500 \\
\hline Fluorene & 170 & & 105 & 160 & & 108 & 5.01 & $\mathrm{U}$ & 5.01 & 6.9 & & 5.3 & 5100000 & & 30300 \\
\hline Indeno(1,2,3-cd)pyrene & 1400 & & 105 & 1200 & & 108 & 5.01 & $\mathrm{U}$ & 5.01 & 120 & & 5.3 & 900000 & & 30300 \\
\hline Naphthalene & 2090 & $\mathrm{U}$ & 2090 & 2150 & $\mathrm{U}$ & 2150 & 100 & $\mathrm{U}$ & 100 & 106 & $\mathrm{U}$ & 106 & 10000000 & & 605000 \\
\hline Phenanthrene & 1100 & & 105 & 990 & & 108 & 5.01 & $\mathrm{U}$ & 5.01 & 190 & & 5.3 & 17000000 & $\mathrm{D}$ & 303000 \\
\hline Pyrene & 2200 & & 210 & 1400 & & 216 & 10 & $\mathrm{U}$ & 10 & 290 & & 10.6 & 9600000 & & 60500 \\
\hline \multicolumn{16}{|c|}{ PCBs (Polychlorinated biphenyls) } \\
\hline Aroclor-1016 & 560 & $\mathrm{U}$ & 560 & 290 & $\mathrm{U}$ & 290 & 13 & $\mathrm{U}$ & 13 & 14 & $\mathrm{U}$ & 14 & 410 & $\mathrm{U}$ & 410 \\
\hline Aroclor-1221 & 560 & $\mathrm{U}$ & 560 & 290 & $\mathrm{U}$ & 290 & 13 & $\mathrm{U}$ & 13 & 14 & $\mathrm{U}$ & 14 & 410 & $\mathrm{U}$ & 410 \\
\hline Aroclor-1232 & 560 & $\mathrm{U}$ & 560 & 290 & $\mathrm{U}$ & 290 & 13 & $\mathrm{U}$ & 13 & 14 & $U$ & 14 & 410 & $\mathrm{U}$ & 410 \\
\hline Aroclor-1242 & 560 & $U$ & 560 & 290 & $\mathrm{U}$ & 290 & 13 & $\mathrm{U}$ & 13 & 14 & $\mathrm{U}$ & 14 & 410 & \begin{tabular}{|l|}
$\mathrm{U}$ \\
\end{tabular} & 410 \\
\hline Aroclor-1248 & 560 & $U$ & 560 & 290 & $\mathrm{U}$ & 290 & 13 & $\mathrm{U}$ & 13 & 14 & $\mathrm{U}$ & 14 & 410 & $\mathrm{U}$ & 410 \\
\hline Aroclor-1254 & 2500 & & 560 & 2300 & & 290 & 13 & $\mathrm{U}$ & 13 & 41 & & 14 & 1000 & & 410 \\
\hline Aroclor- 1260 & 560 & $\mathrm{U}$ & 560 & 290 & $\mathrm{U}$ & 290 & 13 & $\mathrm{U}$ & 13 & 14 & $\mathrm{U}$ & 14 & 410 & $\mathrm{U}$ & 410 \\
\hline
\end{tabular}


Table A-1. 100-F-31 Confirmatory Sampling Results. (5 Pages)

\begin{tabular}{|c|c|c|c|c|c|c|c|c|c|}
\hline \multirow[t]{2}{*}{ Constituent } & \multicolumn{3}{|c|}{$\begin{array}{c}\text { J01Y91 } \\
\text { Septic Tank } \\
\text { Sample Date } 10 / 15 / 04\end{array}$} & \multicolumn{3}{|c|}{$\begin{array}{c}\text { J01Y92 } \\
\text { Duplicate of J01Y91 } \\
\text { Sample Date } 10 / 15 / 04\end{array}$} & \multicolumn{3}{|c|}{$\begin{array}{c}\text { J01Y93 } \\
\text { Equipment Blank } \\
\text { Sample Date 10/15/04 }\end{array}$} \\
\hline & $\mu \mathrm{g} / \mathrm{kg}$ & \begin{tabular}{|l|}
0 \\
\end{tabular} & PQL & $\mu \mathrm{g} / \mathrm{kg}$ & $\mid \mathrm{Q}$ & PQL & $\mu \mathrm{g} / \mathrm{kg}$ & 0 & PQL \\
\hline \multicolumn{10}{|c|}{ SVOAs (Semivolatile organics) } \\
\hline 1,2,4-Trichlorobenzene & 14000 & $\mathrm{U}$ & 14000 & 18000 & $\mathrm{U}$ & 18000 & 330 & $\mathrm{U}$ & 330 \\
\hline 1,2-Dichlorobenzene & 14000 & $\mathrm{U}$ & 14000 & 18000 & $\mathrm{U}$ & 18000 & 330 & $\mathrm{U}$ & 330 \\
\hline 1,3-Dichlorobenzene & 14000 & $\mathrm{U}$ & 14000 & 18000 & $\mathrm{U}$ & 18000 & 330 & $U$ & 330 \\
\hline 1,4-Dichlorobenzene & 14000 & $\mathrm{U}$ & 14000 & 18000 & U & 18000 & 330 & $\mathrm{U}$ & 330 \\
\hline 2,4,5-Trichlorophenol & 35000 & $\mathrm{U}$ & 35000 & 45000 & $\mathrm{U}$ & 45000 & 840 & $\mathrm{U}$ & 840 \\
\hline 2,4,6-Trichlorophenol & 14000 & $\mathrm{U}$ & 14000 & 18000 & $\mathrm{U}$ & 18000 & 330 & $\mathrm{U}$ & 330 \\
\hline 2,4-Dichlorophenol & 14000 & $\mathrm{U}$ & 14000 & 18000 & $\mathrm{U}$ & 18000 & 330 & $\mathrm{U}$ & 330 \\
\hline 2,4-Dimethylphenol & 14000 & $\mathrm{U}$ & 14000 & 18000 & U & 18000 & 330 & $\mathrm{U}$ & 330 \\
\hline 2,4-Dinitrophenol & 35000 & $\mathrm{U}$ & 35000 & 45000 & U & 45000 & 840 & $\mathrm{U}$ & 840 \\
\hline 2,4-Dinitrotoluene & 14000 & $\mathrm{U}$ & 14000 & 18000 & U & 18000 & 330 & $\mathrm{U}$ & 330 \\
\hline 2,6-Dinitrotoluene & 14000 & $\mathrm{U}$ & 14000 & 18000 & $\mathrm{U}$ & 18000 & 330 & $\mathrm{U}$ & 330 \\
\hline 2-Chloronaphthalene & 14000 & $\mathrm{U}$ & 14000 & 18000 & $\mathrm{U}$ & 18000 & 330 & $\mathrm{U}$ & 330 \\
\hline 2-Chlorophenol & 14000 & $\mathrm{U}$ & 14000 & 18000 & $\mathrm{U}$ & 18000 & 330 & $\mathrm{U}$ & 330 \\
\hline 2,2 -oxybis (1-chloropropane) & 14000 & $\mathrm{U}$ & 14000 & 18000 & $\mathrm{U}$ & 18000 & 330 & $\mathrm{U}$ & 330 \\
\hline 2-Methylnaphthalene & 14000 & $\mathrm{U}$ & 14000 & 18000 & $\mathrm{U}$ & 18000 & 330 & $\mathrm{U}$ & 330 \\
\hline 2-Methylphenol (cresol, o-) & 14000 & $\mathrm{U}$ & 14000 & 18000 & $\mathrm{U}$ & 18000 & 330 & $\mathrm{U}$ & 330 \\
\hline 2-Nitroaniline & 35000 & $\mathrm{U}$ & 35000 & 45000 & $\mathrm{U}$ & 45000 & 840 & $\mathrm{U}$ & 840 \\
\hline 2-Nitrophenol & 14000 & $\mathrm{U}$ & 14000 & 18000 & $\mathrm{U}$ & 18000 & 330 & $\mathrm{U}$ & 330 \\
\hline 3,3'-Dichlorobenzidine & 14000 & $\mathrm{U}$ & 14000 & 18000 & $\mathrm{U}$ & 18000 & 330 & $\mathrm{U}$ & 330 \\
\hline 3-Nitroaniline & 35000 & $\mathrm{U}$ & 35000 & 45000 & U & 45000 & 840 & $\mathrm{U}$ & 840 \\
\hline 4,6-Dinitro-2-methylphenol & 35000 & $\mathrm{U}$ & 35000 & 45000 & $\mathrm{U}$ & 45000 & 840 & $\mathrm{U}$ & 840 \\
\hline 4-Bromophenylphenyl ether & 14000 & $\mathrm{U}$ & 14000 & 18000 & U & 18000 & 330 & $\mathrm{U}$ & 330 \\
\hline 4-Chloro-3-methylphenol & 14000 & $\mathrm{U}$ & 14000 & 18000 & $\mathrm{U}$ & 18000 & 330 & $\mathrm{U}$ & 330 \\
\hline 4-Chloroaniline & 14000 & $\mathrm{U}$ & 14000 & 18000 & $\mathrm{U}$ & 18000 & 330 & $\mathrm{U}$ & 330 \\
\hline 4-Chlorophenylphenyl ether & 14000 & $\mathrm{U}$ & 14000 & 18000 & U & 18000 & 330 & $\mathrm{U}$ & 330 \\
\hline 3+4-Methylphenol (cresol, $\mathrm{m}+\mathrm{p}-$ ) & 14000 & $\mathrm{U}$ & 14000 & 18000 & $\mathrm{U}$ & 18000 & 330 & $\mathrm{U}$ & 330 \\
\hline 4-Nitroaniline & 35000 & $\mathrm{U}$ & 35000 & 45000 & $\mathrm{U}$ & 45000 & 840 & $\mathrm{U}$ & 840 \\
\hline 4-Nitrophenol & 35000 & $\mathrm{U}$ & 35000 & 45000 & $\mathrm{U}$ & 45000 & 840 & $\mathrm{U}$ & 840 \\
\hline Acenaphthene & 14000 & $\mathrm{U}$ & 14000 & 2700 & $\mathrm{~J}$ & 18000 & 330 & $\mathrm{U}$ & 330 \\
\hline Acenaphthylene & 14000 & $\mathrm{U}$ & 14000 & 18000 & $\mathrm{U}$ & 18000 & 330 & $\mathrm{U}$ & 330 \\
\hline Anthracene & 790 & $\mathrm{~J}$ & 14000 & 3700 & $\mathrm{~J}$ & 18000 & 330 & $\mathrm{U}$ & 330 \\
\hline Benzo(a)anthracene & 1800 & $\mathrm{~J}$ & 14000 & 7000 & $\mathrm{~J}$ & 18000 & 330 & $\mathrm{U}$ & 330 \\
\hline Benzo(a)pyrene & 14000 & $\mathrm{U}$ & 14000 & 6100 & $\mathrm{~J}$ & 18000 & 330 & $\mathrm{U}$ & 330 \\
\hline Benzo(b)fluoranthene & 1400 & $\mathrm{~J}$ & 14000 & 4600 & $\mathrm{~J}$ & 18000 & 330 & $\mathrm{U}$ & 330 \\
\hline Benzo(ghi)perylene & 1100 & $\mathrm{~J}$ & 14000 & 2400 & $\mathrm{~J}$ & 18000 & 330 & $\mathrm{U}$ & 330 \\
\hline Benzo(k)fluoranthene & 1400 & $\mathrm{~J}$ & 14000 & 5600 & $\mathrm{~J}$ & 18000 & 330 & $\mathrm{U}$ & 330 \\
\hline Bis(2-chloro-1-methylethyl)ether & 14000 & $\mathrm{U}$ & 14000 & 18000 & $\mathrm{U}$ & 18000 & 330 & $\mathrm{U}$ & 330 \\
\hline Bis(2-Chloroethoxy)methane & 14000 & $\mathrm{U}$ & 14000 & 18000 & $\mathrm{U}$ & 18000 & 330 & $\mathrm{U}$ & 330 \\
\hline Bis(2-chloroethyl) ether & 14000 & $\mathrm{U}$ & 14000 & 18000 & $\mathrm{U}$ & 18000 & 330 & $\mathrm{U}$ & 330 \\
\hline Bis(2-ethylhexyl) phthalate & 6400 & $\mathrm{~J}$ & 14000 & 2800 & $\mathrm{~J}$ & 18000 & 33 & $\mathrm{~J}$ & 330 \\
\hline Butylbenzylphthalate & 14000 & $\mathrm{U}$ & 14000 & 18000 & $\mathrm{U}$ & 18000 & 330 & $\mathrm{U}$ & 330 \\
\hline Carbazole & 14000 & $\mathrm{U}$ & 14000 & 1600 & $\mathrm{~J}$ & 18000 & 330 & $\mathrm{U}$ & 330 \\
\hline Chrysene & 2500 & $\mathrm{~J}$ & 14000 & 8700 & $\mathrm{~J}$ & 18000 & 330 & $\mathrm{U}$ & 330 \\
\hline Di-n-butylphthalate & 1000 & $\mathrm{JB}$ & 14000 & 18000 & $\mathrm{U}$ & 18000 & 37 & $\mathrm{JB}$ & 330 \\
\hline Di-n-octylphthalate & 14000 & $\mathrm{U}$ & 14000 & 18000 & $\mathrm{U}$ & 18000 & 330 & $\mathrm{U}$ & 330 \\
\hline Dibenz $[a, h]$ anthracene & 14000 & $\mathrm{U}$ & 14000 & 18000 & $\mathrm{U}$ & 18000 & 330 & $\mathrm{U}$ & 330 \\
\hline Dibenzofuran & 14000 & $\mathrm{U}$ & 14000 & 18000 & $\mathrm{U}$ & 18000 & 330 & $\mathrm{U}$ & 330 \\
\hline Diethylphthalate & 14000 & $\mathrm{U}$ & 14000 & 18000 & U & 18000 & 40 & $\mathrm{~J}$ & 330 \\
\hline Dimethyl phthalate & 14000 & $\mathrm{U}$ & 14000 & 18000 & $\mathrm{U}$ & 18000 & 330 & $\mathrm{U}$ & 330 \\
\hline Fluoranthene & 2600 & $\mathrm{~J}$ & 14000 & 15000 & $\mathrm{~J}$ & 18000 & 330 & $\mathrm{U}$ & 330 \\
\hline Fluorene & 14000 & $\mathrm{U}$ & 14000 & 1500 & $\mathrm{~J}$ & 18000 & 330 & $\mathrm{U}$ & 330 \\
\hline Hexachlorobenzene & 14000 & $\mathrm{U}$ & 14000 & 18000 & $\mathrm{U}$ & 18000 & 330 & $\mathrm{U}$ & 330 \\
\hline Hexachlorobutadiene & 14000 & $\mathrm{U}$ & 14000 & 18000 & $\mathrm{U}$ & 18000 & 330 & $U$ & 330 \\
\hline
\end{tabular}


Table A-1. 100-F-31 Confirmatory Sampling Results. (5 Pages)

\begin{tabular}{|c|c|c|c|c|c|c|c|c|c|}
\hline \multirow[t]{2}{*}{ Constituent } & \multicolumn{3}{|c|}{$\begin{array}{c}\text { J01Y91 } \\
\text { Bottom of tank } \\
\text { Sample Date 10/15/04 }\end{array}$} & \multicolumn{3}{|c|}{$\begin{array}{c}\text { J01Y92 } \\
\text { Bottom of tank } \\
\text { Sample Date 10/15/04 }\end{array}$} & \multicolumn{3}{|c|}{$\begin{array}{c}\text { J01Y93 } \\
\text { Bottom of tank } \\
\text { Sample Date } 10 / 15 / 04\end{array}$} \\
\hline & $\mu \mathrm{g} / \mathrm{kg}$ & Q & PQL & $\mu \mathrm{g} / \mathrm{kg}$ & $\mathbf{Q}$ & PQL & $\mu \mathrm{g} / \mathrm{kg}$ & $\mathbf{Q}$ & PQL \\
\hline \multicolumn{10}{|c|}{ SVOAs (continued) } \\
\hline Hexachlorocyclopentadiene & 14000 & $\mathrm{U}$ & 14000 & 18000 & $\mathrm{U}$ & 18000 & 330 & $\mathrm{U}$ & 330 \\
\hline Hexachloroethane & 14000 & $\mathrm{U}$ & 14000 & 18000 & $\mathrm{U}$ & 18000 & 330 & $\mathrm{U}$ & 330 \\
\hline Indeno(1,2,3-cd)pyrene & 1100 & $\mathrm{~J}$ & 14000 & 2400 & $\mathrm{~J}$ & 18000 & 330 & $\mathrm{U}$ & 330 \\
\hline Isophorone & 14000 & $\mathrm{U}$ & 14000 & 18000 & $\mathrm{U}$ & 18000 & 330 & $\mathrm{U}$ & 330 \\
\hline N-Nitroso-di-n-dipropylamine & 14000 & $\mathrm{U}$ & 14000 & 18000 & $\mathrm{U}$ & 18000 & 330 & $\mathrm{U}$ & 330 \\
\hline N-Nitrosodiphenylamine & 14000 & $\mathrm{U}$ & 14000 & 18000 & $\mathrm{U}$ & 18000 & 330 & $\mathrm{U}$ & 330 \\
\hline Naphthalene & 14000 & $\mathrm{U}$ & 14000 & 18000 & $\mathrm{U}$ & 18000 & 330 & $\mathrm{U}$ & 330 \\
\hline Nitrobenzene & 14000 & $\mathrm{U}$ & 14000 & 18000 & $\mathrm{U}$ & 18000 & 330 & $\mathrm{U}$ & 330 \\
\hline Pentachlorophenol & 35000 & $\mathrm{U}$ & 35000 & 45000 & $\mathrm{U}$ & 45000 & 840 & $\mathrm{U}$ & 840 \\
\hline Phenanthrene & 1600 & $\mathrm{~J}$ & 14000 & 14000 & $\mathrm{~J}$ & 18000 & 330 & $\mathrm{U}$ & 330 \\
\hline Phenol & 14000 & $\mathrm{U}$ & 14000 & 18000 & $\mathrm{U}$ & 18000 & 330 & $\mathrm{U}$ & 330 \\
\hline Pyrene & 3000 & $\mathrm{~J}$ & 14000 & 17000 & $\mathrm{~J}$ & 18000 & 330 & $\mathrm{U}$ & 330 \\
\hline
\end{tabular}


Table A-2. 100-F-31 Waste Characterization Data Results. (3 Pages)

\begin{tabular}{|c|c|c|c|c|c|c|c|c|c|c|c|c|c|c|c|c|c|c|c|c|}
\hline \multirow{2}{*}{ Sample Location } & \multirow{2}{*}{$\begin{array}{c}\text { HEIS } \\
\text { Number }\end{array}$} & \multirow{2}{*}{$\begin{array}{c}\text { Sample } \\
\text { Date }\end{array}$} & \multicolumn{3}{|c|}{ Americium-241 GEA } & \multicolumn{3}{|c|}{ Cesium-137 } & \multicolumn{3}{|c|}{ Cobalt-60 } & \multicolumn{3}{|c|}{ Europium-152 } & \multicolumn{3}{|c|}{ Europium-154 } & \multicolumn{3}{|c|}{ Europium-155 } \\
\hline & & & $\mathrm{pCi} / \mathrm{g}$ & $\mathrm{Q}$ & MDA & $\mathrm{Ci} / \mathrm{g}$ & $Q$ & MDA & $\mathrm{Ci} / \mathrm{g}$ & Q & MDA & $\mathrm{pCi} / \mathrm{g}$ & Q & MDA & $\mathrm{pCi} / \mathrm{g}$ & Q & MDA & $\mathrm{pCi} / \mathrm{g}$ & $\mathrm{Q}$ & MDA \\
\hline & $\mathrm{J} 03 \mathrm{~W} 88$ & $8 / 15 / 05$ & 0.34 & $\mathrm{U}$ & 0.34 & 0.068 & & 0.052 & 0.046 & $\mathrm{U}$ & 0.0 & 0.134 & & 0.1 & 0.16 & $\mathrm{U}$ & 0.16 & 0.13 & $\mathrm{U}$ & 0.13 \\
\hline Waste S & $\mathrm{J}_{03}$ & $8 / 1$ & 0.15 & 5 & 0.15 & 0.04 & & 0.04 & 0.044 & & 0.0 & 0.1 & & 0.1 & 0.14 & $\bar{U}$ & 0.1 & .079 & $\mathrm{U}$ & 0.1 \\
\hline
\end{tabular}

\begin{tabular}{|c|c|c|c|c|c|c|c|c|c|c|c|c|c|c|c|c|c|c|c|c|}
\hline \multirow{2}{*}{ Sample Location } & \multirow{2}{*}{\begin{tabular}{|c|} 
HEIS \\
Number
\end{tabular}} & \multirow{2}{*}{$\begin{array}{c}\text { Sample } \\
\text { Date }\end{array}$} & \multicolumn{3}{|c|}{ Nickel-63 } & \multicolumn{3}{|c|}{ Plutonium-238 } & \multicolumn{3}{|c|}{ Plutonium-239/240 } & \multicolumn{3}{|c|}{ Potassium-40 } & \multicolumn{3}{|c|}{ Radium-226 } & \multicolumn{3}{|c|}{ Radium-228 } \\
\hline & & & $\mathrm{pCi} / \mathrm{g}$ & $Q$ & MDA & $\mathrm{pCi} / \mathrm{g}$ & $\mathrm{Q}$ & MDA & $\mathrm{pCi} / \mathrm{g}$ & $Q$ & MDA & $\mathrm{pCi} / \mathrm{g}$ & Q & MDA & $\mathrm{pCi} / \mathrm{g}$ & $Q$ & MDA & $\mathrm{pCi} / \mathrm{g}$ & $\mathbf{Q}$ & MDA \\
\hline Waste S & J03W88 & $8 / 15 / 05$ & -1.53 & $\mathrm{U}$ & 3.9 & 0 & $\mathrm{U}$ & 0.35 & 0 & $\mathrm{U}$ & 0.35 & 14.5 & & 0.44 & 0.608 & & 0.081 & 0.684 & & 0.2 \\
\hline Waste Sample & J03W89 & $8 / 15 / 05$ & -0.505 & $\mathrm{U}$ & 3.9 & 0 & U & 0.25 & 0 & $U$ & 0.25 & 14.4 & & 0.27 & 0.563 & & 0.07 & 0.805 & & 0.18 \\
\hline
\end{tabular}

\begin{tabular}{|c|c|c|c|c|c|c|c|c|c|c|c|c|c|c|c|c|c|}
\hline \multirow{2}{*}{ Sample Location } & \multirow{2}{*}{$\begin{array}{c}\text { HEIS } \\
\text { Number }\end{array}$} & \multirow{2}{*}{$\begin{array}{c}\text { Sample } \\
\text { Date }\end{array}$} & \multicolumn{3}{|c|}{ Thorium-228 GEA } & \multicolumn{3}{|c|}{ Thorium-232 GEA } & \multicolumn{3}{|c|}{ Total beta } & \multicolumn{3}{|c|}{ Uranium-235 GEA } & \multicolumn{3}{|c|}{ Uranium-238 } \\
\hline & & & $\mathrm{pCi} / \mathrm{g}$ & $Q$ & MDA & $\mathrm{pCi} / \mathrm{g}$ & $\mathbf{Q}$ & MDA & $\mathrm{pCi} / \mathrm{g}$ & $\mathbf{Q}$ & MDA & $\mathrm{pCi} / \mathrm{g}$ & $\mathbf{Q}$ & MDA & $\mathrm{pCi} / \mathrm{g}$ & $Q$ & MDA \\
\hline Waste Sample & J03W88 & $8 / 15 / 05$ & 0.699 & & 0.049 & 0.684 & & 0.2 & 0.042 & $\mathrm{U}$ & 0.31 & 0.19 & $\bar{U}$ & 0.19 & 5.6 & $\mathrm{U}$ & 5.6 \\
\hline Waste Sample & J03W89 & $8 / 15 / 05$ & 0.69 & & 0.045 & 0.805 & & 0.18 & 0.054 & $U$ & 0.3 & 0.15 & $\mathrm{U}$ & 0.15 & 5.2 & $U$ & 5.2 \\
\hline
\end{tabular}


Table A-2. 100-F-31 Waste Characterization Data Results. (3 Pages)

\begin{tabular}{|c|c|c|c|c|c|c|c|c|c|c|c|c|c|c|c|c|c|c|c|c|c|c|}
\hline \multirow{2}{*}{$\begin{array}{l}\text { Sample } \\
\text { Location }\end{array}$} & \multirow{2}{*}{$\begin{array}{c}\text { HEIS } \\
\text { Number }\end{array}$} & \multirow{2}{*}{$\begin{array}{c}\text { Sample } \\
\text { Date }\end{array}$} & \multicolumn{3}{|c|}{ Aluminum } & \multicolumn{3}{|c|}{ Antimony } & \multicolumn{3}{|c|}{ Arsenic } & \multicolumn{3}{|c|}{ Barium } & \multicolumn{3}{|c|}{ Beryllium } & \multicolumn{3}{|c|}{ Boron } & \multicolumn{2}{|c|}{ Cadmium } \\
\hline & & & $\mathrm{mg} / \mathrm{kg}$ & $Q$ & $\mathbf{P Q L}$ & $\mathrm{mg} / \mathrm{kg}$ & Q & $\mathrm{PQL}$ & $\mathrm{mg} / \mathrm{kg}$ & $Q$ & PQL & $\mathrm{mg} / \mathrm{kg}$ & Q & $\mathbf{P Q L}$ & $\mathrm{mg} / \mathrm{kg}$ & $Q$ & PQL & $\mathrm{mg} / \mathrm{kg}$ & $\mathrm{Q}$ & $\mathrm{PQL}$ & $\mathrm{mg} / \mathrm{kg}$ & \begin{tabular}{l|l|}
$\mathrm{Q}$ & $\mathrm{PQL}$ \\
\end{tabular} \\
\hline Waste Sample & J03W88 & $8 / 8 / 05$ & 4070 & C & 15.2 & 2.5 & $\overrightarrow{\mathrm{U}}$ & 2.5 & 6.6 & & 2.8 & 57 & C & 0.12 & 0.49 & C & 0.06 & 9.6 & C & 1.4 & 0.2 & 0.18 \\
\hline Waste Sample & J03W89 & $8 / 8 / 05$ & 3750 & C & 14.2 & 2.3 & $\mathrm{U}$ & 2.3 & 4.7 & & 2.6 & 31.4 & C & 0.11 & 0.5 & C & 0.06 & 3 & c| & 1.3 & 0.2 & 0.17 \\
\hline
\end{tabular}

\begin{tabular}{|c|c|c|c|c|c|c|c|c|c|c|c|c|c|c|c|c|c|c|c|c|c|c|c|}
\hline \multirow{2}{*}{$\begin{array}{l}\text { Sample } \\
\text { Location }\end{array}$} & \multirow{2}{*}{$\begin{array}{c}\text { HEIS } \\
\text { Number }\end{array}$} & \multirow{2}{*}{$\begin{array}{c}\text { Sample } \\
\text { Date }\end{array}$} & \multicolumn{3}{|c|}{ Calcium } & \multicolumn{3}{|c|}{ Chromium } & \multicolumn{3}{|c|}{ Cobalt } & \multicolumn{3}{|c|}{ Copper } & \multicolumn{3}{|c|}{$\begin{array}{l}\text { Hexavalent } \\
\text { Chromium }\end{array}$} & \multicolumn{3}{|c|}{ Iron } & \\
\hline & & & $\mathrm{mg} / \mathrm{kg}$ & oा & PQL & $\mathrm{mg} / \mathrm{kg}$ & & $\mathrm{PQL}$ & $\mathrm{g} / \mathrm{kg}$ & & $\mathrm{PQL}$ & $\mathrm{g} / \mathrm{kg}$ & & PQL & $\mathrm{mg} / \mathrm{kg}$ & $Q$ & PQL & $\mathrm{g} / \mathrm{kg}$ & & $\mathbf{P Q L}$ & $\mathrm{mg} / \mathrm{kg}$ & $Q$ & $\overline{\mathrm{PQL}}$ \\
\hline Waste Sample & J03W88 & $8 / 8 / 05$ & 4080 & C & 3.9 & 7.1 & & 0.43 & 4 & & 0.55 & 11.3 & & 0.49 & 0.22 & U & 0.22 & 11100 & & 18.1 & 10.3 & & 1.5 \\
\hline Waste Sample & J03W89 & $8 / 8 / 05$ & 3360 & $\mathrm{C}$ & 3.7 & 6.9 & & 0.4 & 3.7 & & 0.52 & 12.6 & & 0.46 & 0.24 & & 0.21 & 11200 & & 16.8 & 3.3 & & 1.4 \\
\hline
\end{tabular}

\begin{tabular}{|c|c|c|c|c|c|c|c|c|c|c|c|c|c|c|c|c|c|c|c|c|c|c|}
\hline \multirow{2}{*}{$\begin{array}{c}\text { Sample } \\
\text { Location }\end{array}$} & \multirow{2}{*}{$\begin{array}{c}\text { HEIS } \\
\text { Number }\end{array}$} & \multirow{2}{*}{$\begin{array}{c}\text { Sample } \\
\text { Date }\end{array}$} & \multicolumn{3}{|c|}{ Magnesium } & \multicolumn{2}{|c|}{ Manganese } & \multicolumn{3}{|c|}{ Mercury } & \multicolumn{3}{|c|}{ Molybdenum } & \multicolumn{3}{|c|}{ Nickel } & \multicolumn{3}{|c|}{ Potassium } & \multicolumn{3}{|c|}{ Selenium } \\
\hline & & & $\mathrm{mg} / \mathrm{kg}$ & $Q$ & $\overline{\mathrm{PQL}}$ & $\mathrm{mg} / \mathrm{kg}$ & \begin{tabular}{|l|l|}
$\mathrm{Q}$ & $\mathrm{PQL}$ \\
\end{tabular} & $\mathrm{mg} / \mathrm{kg}$ & $Q$ & PQL & $\mathrm{mg} / \mathrm{kg}$ & $Q$ & PQL & $\mathrm{mg} / \mathrm{kg}$ & $\bar{Q}$ & PQL & $\mathrm{mg} / \mathrm{kg}$ & 8 & PQL & $\mathrm{mg} / \mathrm{kg}$ & $Q$ & $\mathrm{PQL}$ \\
\hline Waste Sample & J03W88 & $8 / 8 / 05$ & 2770 & C & 4.1 & 216 & 0.12 & 0.04 & & 0.02 & 0.99 & $\mathrm{U}$ & 0.99 & 8.3 & & 1.4 & 735 & C & 19.2 & 3 & U & 3 \\
\hline Waste Sample & J03W89 & $8 / 8 / 05$ & 2780 & C & 3.9 & 191 & 0.11 & 0.01 & $\mathrm{U}$ & 0.01 & 0.92 & $\mathrm{U}$ & 0.92 & 7.2 & & 1.3 & 510 & $\mathrm{C}$ & 17.9 & 2.8 & U & 2.8 \\
\hline
\end{tabular}

\begin{tabular}{|c|c|c|c|c|c|c|c|c|c|c|c|c|c|c|c|c|c|c|c|c|}
\hline \multirow{2}{*}{$\begin{array}{l}\text { Sample } \\
\text { Location }\end{array}$} & \multirow{2}{*}{$\begin{array}{l}\text { HEIS } \\
\text { Number }\end{array}$} & \multirow{2}{*}{$\begin{array}{l}\text { Sample } \\
\text { Date }\end{array}$} & \multicolumn{3}{|c|}{ Silicon } & \multicolumn{3}{|c|}{ Silver } & \multicolumn{3}{|c|}{ Sodium } & \multicolumn{3}{|c|}{ Vanadium } & \multicolumn{3}{|c|}{ Zine } & \multicolumn{3}{|c|}{$\begin{array}{l}\text { Total Petroleum } \\
\text { Hydrocarbons }\end{array}$} \\
\hline & & & $\mathrm{mg} / \mathrm{kg}$ & Q & PQL & $\mathrm{mg} / \mathrm{kg}$ & $Q$ & $\mathrm{PQL}$ & $\mathrm{mg} / \mathrm{kg}$ & $Q$ & $\mathrm{PQL}$ & $\mathrm{mg} / \mathrm{kg}$ & $Q$ & \begin{tabular}{|l|} 
PQL \\
\end{tabular} & $\mathrm{mg} / \mathrm{kg}$ & $Q$ & \begin{tabular}{|l|}
$\mathrm{PQL}$ \\
\end{tabular} & $\mathrm{mg} / \mathrm{kg}$ & $Q$ & PQL \\
\hline Waste Sample & J03W88 & $8 / 8 / 05$ & 447 & C & 4.2 & 0.55 & $\mathrm{U}$ & 0.55 & 82.5 & C & 0.92 & 25.5 & & \begin{tabular}{|l|}
0.37 \\
\end{tabular} & 32.9 & & \begin{tabular}{|l|}
0.31 \\
\end{tabular} & 147 & U & 147 \\
\hline Waste Sample & J03W89 & $8 / 8 / 05$ & 393 & C & 3.9 & 0.52 & $\mathrm{U}$ & \begin{tabular}{|l|}
0.52 \\
\end{tabular} & 76 & C & \begin{tabular}{|l|l|}
0.86 \\
\end{tabular} & 26.9 & & \begin{tabular}{|l|}
0.34 \\
\end{tabular} & 26.6 & & \begin{tabular}{|l|}
0.29 \\
\end{tabular} & 138 & U & 138 \\
\hline
\end{tabular}


Table A-2. 100-F-31 Waste Characterization Data Results. (3 Pages)

\begin{tabular}{|c|c|c|c|c|c|c|}
\hline \multirow[t]{2}{*}{ Constituents } & \multicolumn{3}{|c|}{$\begin{array}{c}\text { J03W88 } \\
\text { Waste Sample } \\
\text { Sample Date } 8 / 15 / 05 \\
\end{array}$} & \multicolumn{3}{|c|}{$\begin{array}{c}\text { J03W89 } \\
\text { Waste Sample } \\
\text { Sample Date } 8 / 15 / 05 \\
\end{array}$} \\
\hline & $\mu \mathrm{g} / \mathrm{kg}$ & $Q$ & PQL & $\mu \mathrm{g} / \mathrm{kg}$ & $Q$ & PQL \\
\hline \multicolumn{7}{|c|}{ Polycyclic Aromatic Hydrocarbons (PAHs) } \\
\hline Acenaphthene & 55.5 & $\mathrm{U}$ & 55.5 & 52.2 & $U$ & 52.2 \\
\hline Acenaphthylene & 55.5 & $\mathrm{U}$ & 55.5 & 52.2 & $\mathrm{U}$ & 52.2 \\
\hline Anthracene & 5.55 & $\mathrm{U}$ & 5.55 & 5.22 & $\mathrm{U}$ & 5.22 \\
\hline Benzo(a)anthracene & 33 & & 5.55 & 5.22 & $\mathrm{U}$ & 5.22 \\
\hline Benzo(a)pyrene & 40 & & 5.55 & 5.22 & $\mathrm{U}$ & 5.22 \\
\hline Benzo(b)fluoranthene & 48 & & 5.55 & 4.6 & $\mathrm{~J}$ & 5.22 \\
\hline Benzo(ghi)perylene & 18 & & 5.55 & 5.22 & $\mathrm{U}$ & 5.22 \\
\hline Benzo(k)fluoranthene & 19 & & 5.55 & 5.22 & $\mathrm{U}$ & 5.22 \\
\hline Chrysene & 54 & & 5.55 & 5.5 & & 5.22 \\
\hline Dibenz $[a, h]$ anthracene & 5.3 & $\mathrm{~J}$ & 5.55 & 5.22 & $\mathrm{U}$ & 5.22 \\
\hline Fluoranthene & 84 & & 11.1 & 50 & & 10.4 \\
\hline Fluorene & 5.55 & $\mathrm{U}$ & 5.55 & 5.22 & $\mathrm{U}$ & 5.22 \\
\hline Indeno(1,2,3-cd)pyrene & 11 & & 5.55 & 5.22 & $\mathrm{U}$ & 5.22 \\
\hline Naphthalene & 55.5 & $\mathrm{U}$ & 55.5 & 52.2 & $\mathrm{U}$ & 52.2 \\
\hline Phenanthrene & 27 & & 5.55 & 5.22 & $\mathrm{U}$ & 5.22 \\
\hline Pyrene & 62 & & 11.1 & 10.4 & $\mathrm{U}$ & 10.4 \\
\hline
\end{tabular}




\section{APPENDIX B}

\section{VERIFICATION SAMPLING RESULTS AND 95\% UCL CALCULATIONS}




\section{CALCULATION COVER SHEET}

Project Title:

Area

Discipline

Subject

Computer Program

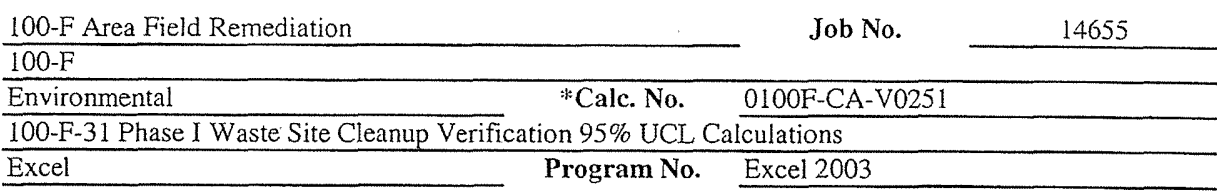

The attached calculations have been generated to document compliance with established cleanup levels. These calculations should be used in conjunction with other relevant documents in the administrative record.

Committed Calculation $\quad x \quad$ Preliminary $\square \quad$ Superseded $\square \quad$ Voided $\square$

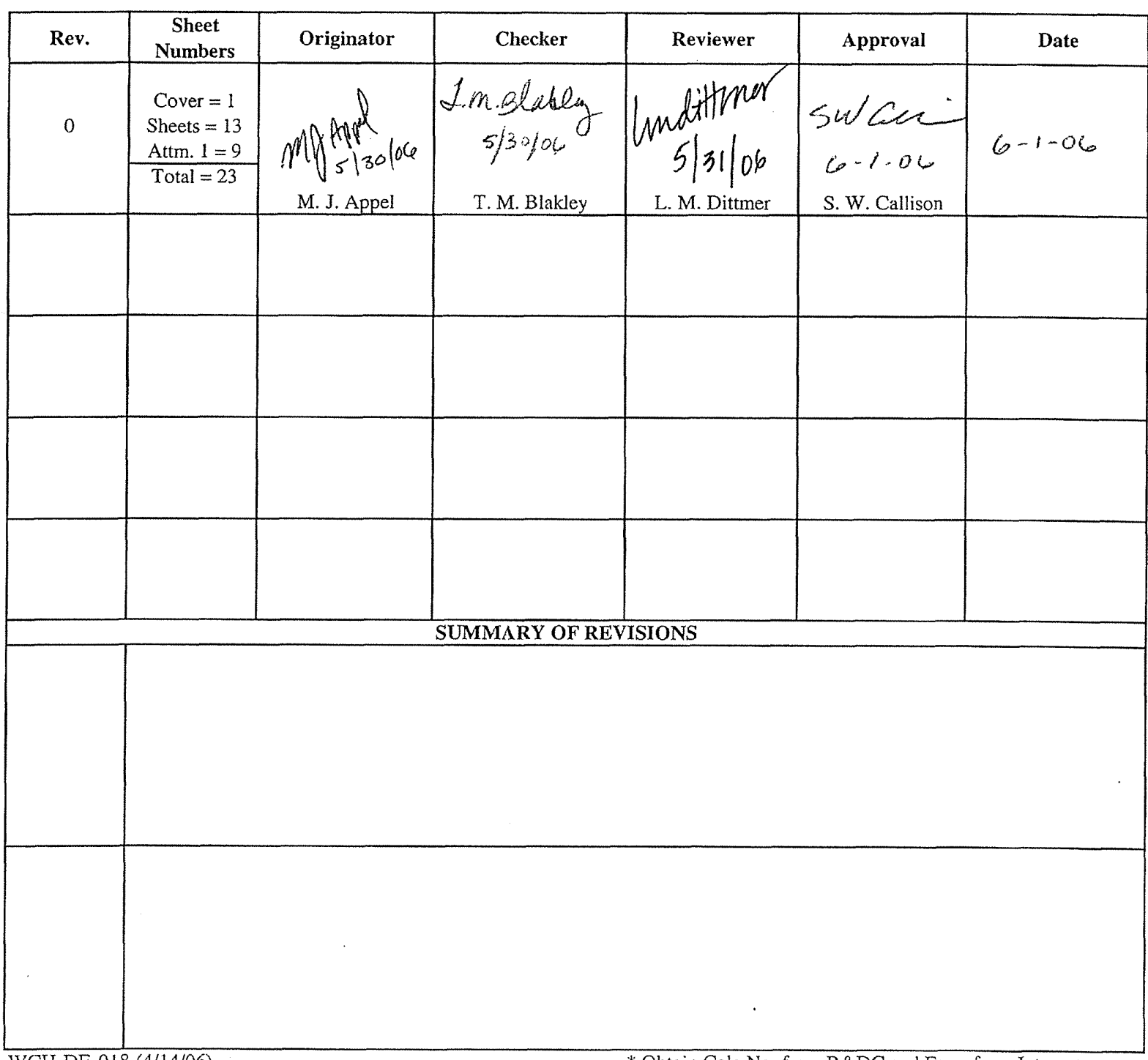

WCH-DE-018(4/14/06)

* Obtain Calc No. from R\&DC and Form from Intranet 


\section{CALCULATION SHEET}

\section{Washington Closure Hanford}

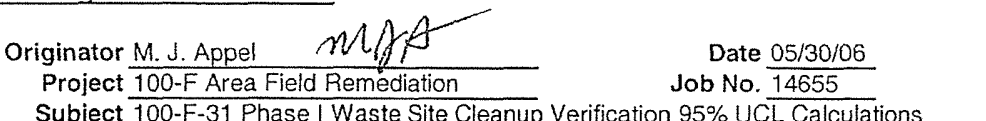

Calc. No. 0100F-CA-V0251 Checked T.M. Blakley trits
Rev. No. 0 Date $2 / 1 / 20$ Sheet No. 1 of 13

Summary

\section{Purpose:}

Calculate the $95 \%$ upper confidence limit (UCL) values to evaluate compliance with cleanup standards for the remediation footprint of the subject site. Also, perform the Washington Administrative Code (WAC) 173-340-740(7)(e) 3-part test for nonradionuclide analytes and calculate the relative percent difference (RPD) for primary-duplicate sample pairs for each contaminant of concern (COC) and contaminant of potential concern (COPC), as necessary.

Table of Contents:

Sheets 1 to 3 - Calculation Sheet Summary

Sheets 4 to 6 - Calculation Sheet Verification Data

Sheet 7 - Calculation Sheet Duplicate Analysis

Sheets 8 to 13 - Ecology Software (MTCAStat) Results

Attachment 1 - 100-F-31 Verification Sampling Results (11 sheets)

Given/References:

1) Sample Results (Attachment 1).

2) Background values and remedial action goals (RAGs) are taken from DOE-RL (2005b), DOE-RL (2001), and Ecology (2005)

3) DOE-RL, 2001, Hanford Site Background: Part 1, Soil Background for Nonradioactive Analytes, DOE/RL-92-24, Rev. 4, U.S. Department of Energy, Richland Operations Office, Richland, Washington.

4) DOE-RL, 2005a, 100 Area Remedial Action Sampling and Analysis Plan (SAP), DOE/RL-96-22, Rev. 4, U.S. Department of Energy, Richland Operations Office, Richland, Washington.

5) DOE-RL, 2005b, Remedial Design Report/Remedial Action Work Plan for the 100 Area (RDR/RAWP), DOE/RL-96-17, Rev. 5, U.S. Department of Energy, Richland Operations Office, Richland, Washington.

6) Ecology, 1992, Statistical Guidance for Ecology Site Managers, Publication \#92-54, Washington Department of Ecology, Olympia, Washington.

7) Ecology, 1993, Statistical Guidance for Ecology Site Managers, Supplement S-6, Analyzing Site or Background Data with Below-detection Limit or Below-PQL Values (Censored Data Sets), Publication \#92-54, Washington Department of Ecology, Olympia, Washington.

8) Ecology, 2005, Cleanup Levels and Risk Calculations (CLARC) Database, Washington State Department of Ecology, Olympia, Washington, <https://fortress.wa.gov/ecy/clarc/CLARCHome.aspx>.

9) EPA, 1994, USEPA Contract Laboratory Program National Functional Guidelines for Inorganic Data Review, EPA 540/R-94/013. U.S. Environmental Protection Agency, Washington, D.C.

10) WAC 173-340, 1996, "Model Toxic Control Act - Cleanup," Washington Administrative Code.

Solution:

Calculation methodology is described in Ecology Pub. \#92-54 (Ecology 1992, 1993), below, and in the RDR/RAWP (DOE-RL 2005b). Use data from attached worksheets to perform the $95 \%$ UCL calculation for each analyte, the

WAC 173-340-740(7)(e) 3-part test for nonradionuclides, and the RPD calculations for each COC/COPC, as required. The hazard quotient and carcinogenic risk calculations are located in a separate calculation brief as an appendix to the Remaining Sites Verification Package (RSVP).

Calculation Description:

The subject calculations were performed on data from soil verification samples from the subject waste site. The data were entered into an EXCEL 2003 spreadsheet and calculations performed by using the built-in spreadsheet functions and/or creating formulae within the cells. The statistical evaluation of data for use in accordance with the RDR/RAWP (DOE-RL 2005b) is documented by this calculation. Duplicate RPD results are used in evaluation of data quality within the RSVP for this site. 


\section{Washington Closure Hanford}

\begin{tabular}{|c|c|}
\hline Originator M. J. Appel & Date $05 / 30 / 06$ \\
\hline Project $100-\mathrm{F}$ Area Field Rentediation & Job No. 14655 \\
\hline
\end{tabular}

Summary (continued)

Methodology:

For nonradioactive analytes with $\leq 50 \%$ of the data below detection limits and all radionuclide analytes, the statistical value calculated to evaluate the effectiveness of cleanup is the $95 \%$ UCL. The $95 \%$ UCL was not calculated for radionuclide data sets with no reported detections. The $95 \%$ UCL values were also not calculated for radium-226, radium-228, thorium-228, thorium-

232, and potassium-40, as these isotopes are not related to the operational history of the site and thus not considered COPCs. For nonradioactive analytes with $>50 \%$ of the data below detection limits, the maximum detected value for the data set is used instead of the $95 \% \cup \mathrm{UCL}$. The evaluation of the portion of the data set below detection limits was performed by direct inspection of the attached sample results. The $95 \%$ UCL values were not calculated for aluminum, calcium, iron, magnesium, potassium, silicon, and silver, as no cleanup values are published in Ecology (2005) under WAC 173-340-740(3), and these constituents are thus not considered site COPCs.

All nonradionuclide data reported as being undetected are set to $1 / 2$ the detection limit value for calculation of the statistics (Ecology 1993). For the purpose of the statistical calculations, the PQL was raised to the quantified result for values that were qualified as nondetects by third party validation. For radionuclide data, calculation of the statistics was done on the reported value. In cases where the laboratory does not report a value below the minimal detectable activity (MDA), half of the MDA is used in the calculation. For the statistical evaluation of duplicate sample pairs, the samples are averaged before being included in the data set, after adjustments for censored data as described above.

For nonradionuclides, the WAC 173-340 statistical guidance suggests that a test for distributional form be performed on the data and the $95 \%$ UCL calculated on the appropriate distribution using Ecology software. For nonradionuclide small data sets (n< 10) and all radionuclide data sets, the calculations are performed assuming nonparametric distribution, so no tests for distribution are performed. For nonradionuclide data sets of ten or greater, as for the subject site, distributional testing and calculation of the 95\% UCL is done using Ecology's MTCAStat software (Ecology 1993). Due to differences in addressing censored data between the RDR/RAWP (DOE-RL 2005b) and MTCAStat coding and due to a limitation in the MTCAStat coding (no direct capability to address variable quantitation limits within a data set), substitutions for censored data are performed before software input and the resulting data set treated as uncensored.

The WAC 173-340-740(7)(e) 3-part test is performed for nonradionuclide analytes only and determines if: 1) the $95 \%$ UCL exceeds the most stringent cleanup limit for each COPC/COC,

2) greater than $10 \%$ of the raw data exceed the most stringent cleanup limit for each COPC/COC,

3) the maximum value of the raw data set exceeds two times the most stringent cleanup limit for each $\mathrm{COPC} / \mathrm{COC}$.

The WAC 173-340-740(7)(e) 3-part test is not performed for data sets where the statistical value defaults to the maximum value, as direct comparison of the maximum against site RAGs (within the RSVP) is more conservative.

The RPD is calculated when both the primary value and the duplicate are above detection limits and are greater than 5 times the target detection limit (TDL). The TDL is a laboratory detection limit pre-determined for each analytical method, listed in Table $11-1$ of the SAP (DOE-RL 2005a). Where direct evaluation of the attached sample data showed that a given analyte was not detected in the primary and/or duplicate sample, further evaluation of the RPD value was not performed. The RPD calculations use the following formula:

$$
R P D=[|M-S| /((M+S) / 2)]^{\star-100}
$$

$$
\text { where, } \quad M=\text { main sample value } \quad S=\text { split (or duplicate) sample value }
$$

or quality assurance/quality control (QAQC) split and duplicate RPD calculations, a value less than $30 \%$ indicates the data compare favorably. For regulatory splits, a threshold of $35 \%$ is used (EPA 1994). If the RPD is greater than $30 \%$ (or $35 \%$ for regulatory split data), further investigation regarding the usability of the data is performed. No split samples were collected for cleanup verification of the subject site. Additional discussion is provided in the data quality assessment section of the applicable RSVP, as necessary.

The verification data results, as provided in Attachment 1 , indicated that this site failed for polychlorinated biphenyls (PCBs). These results were not included within this calculation brief, as further remediation has been performed at the 100-F-31 waste site to remove the PCB contamination. An additional statistical verification sampling event (Phase II) will be conducted at the 100-F-31 waste site to analyze for any residual PCB contamination. The results of the Phase II soil sampling effort will be evaluated and documented in a separate calculation brief. The results from both sampling events (Phase I and Phase II) will be presented and discussed in detail within the RSVP for the 100-F-31 waste site. 


\section{Washington Closure Hanford}

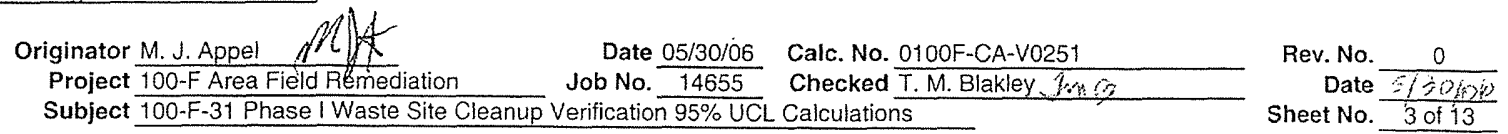

1 Summary (continued)

2 Results:

3 The results presented in the summary tables that follow are for use in risk analysis and the RSVP for this site.

\section{$5 \longdiv { \text { Results Summary - Remediation Footprint } }$}

\begin{tabular}{|c|c|c|c|c|}
\hline 9 & $\operatorname{Res}$ & ts Summary & - Remediatic & \\
\hline 6 & Analyte & $95 \% \mathrm{UCL}^{3}$ & Maximum $^{b}$ & Units \\
\hline 7 & Arsenic & 5.0 & & $\mathrm{mg} / \mathrm{kg}$ \\
\hline 8 & Barium & 86.9 & & $\mathrm{mg} / \mathrm{kg}$ \\
\hline 9 & Beryllium & 0.17 & & $\mathrm{mg} / \mathrm{kg}$ \\
\hline 10 & Boron & 2.7 & & $\mathrm{mg} / \mathrm{kg}$ \\
\hline 11 & Cadmium & 0.66 & & $\mathrm{mg} / \mathrm{kg}$ \\
\hline 12 & Chromium & 9.3 & & $\mathrm{mg} / \mathrm{kg}$ \\
\hline 13 & Hexavalent Chromium & 0.3 & & $\mathrm{mg} / \mathrm{kg}$ \\
\hline 14 & Cobalt & 4.5 & & $\mathrm{mg} / \mathrm{kg}$ \\
\hline 15 & Copper & 13.9 & & $\mathrm{mg} / \mathrm{kg}$ \\
\hline 16 & Lead & 13.0 & & $\mathrm{mg} / \mathrm{kg}$ \\
\hline 17 & Manganese & 230 & & $\mathrm{mg} / \mathrm{kg}$ \\
\hline 18 & Nickel & 10.0 & & $\mathrm{mg} / \mathrm{kg}$ \\
\hline 19 & Vanadium & 33.6 & & $\mathrm{mg} / \mathrm{kg}$ \\
\hline 20 & Zinc & 47.2 & & $\mathrm{mg} / \mathrm{kg}$ \\
\hline 21 & Benzo(a)anthracene & 0.13 & & $\mathrm{mg} / \mathrm{kg}$ \\
\hline 22 & Benzo(a)pyrene & 0.15 & & $\mathrm{mg} / \mathrm{kg}$ \\
\hline 23 & Benzo(b)fluoranthene & 0.15 & & $\mathrm{mg} / \mathrm{kg}$ \\
\hline 24 & Benzo $(g, h, i) p e r y i \in n e$ & & 0.028 & $\mathrm{mg} / \mathrm{kg}$ \\
\hline 25 & Benzo(k)fluoranthene & 0.13 & & $\mathrm{mg} / \mathrm{kg}$ \\
\hline 26 & Chrysene & 0.11 & & $\mathrm{mg} / \mathrm{kg}$ \\
\hline 27 & Fluoranthene & 0.17 & & $\mathrm{mg} / \mathrm{kg}$ \\
\hline 28 & Indeno $(1,2,3$-cd)pyrene & & 0.025 & $\mathrm{mg} / \mathrm{kg}$ \\
\hline 29 & Phenanthrene & & 0.034 & $\mathrm{mg} / \mathrm{kg}$ \\
\hline 30 & Pyrene & 0.18 & & $\mathrm{mg} /$ \\
\hline
\end{tabular}

\begin{tabular}{l|lcc|}
31 & & \\
32 & WAC 173-340-740(7)(e) Evaluation & \\
33 & & Because of the "yes" answers to \\
34 & WAC 173-340 3-Part Test for most stringent RAG: & the WAC 173-340 3-part test for \\
35 & $95 \%$ UCL > Cleanup Limit? & YES & lead detailed assessments \\
36 & $>10 \%$ above Cleanup Limit? & NO & using RESRAD will be \\
37 & Any sample $>$ 2x Cleanup Limit? & NO & performed. All data sets meet \\
38 & & & the 3-part test criteria when \\
39 & & compared to direct exposure \\
40 & & cleanup levels.
\end{tabular}

$41{ }^{\mathrm{a}}$ For nonradionuclides, where $\leq 50 \%$ of a data set is censored (below detection limits),

42 the $95 \%$ UCL value is used for a given analyte.

43 "Where $>50 \%$ of a data set is censored, the statistical value defaults to the maximum

44 detected value in the data set (Attachment 1).

45 MTCA $=$ Model Toxic Control Act

$46 \mathrm{RAG}=$ remedial action goal

47 RESRAD = RESidual RADioactivity (dose assessment model)

$48 \mathrm{UCL}=$ upper confidence level

49 WAC $=$ Washington Adminstrative Code

50

\begin{tabular}{|c|c|c|}
\hline 51 & Relative Per & erence \\
\hline & Analyte & $\begin{array}{l}\text { Duplicate } \\
\text { Analysis }\end{array}$ \\
\hline & Barium & $11.7 \%$ \\
\hline & Chromium & $16.8 \%$ \\
\hline & Copper & $7.9 \%$ \\
\hline & Manganese & $15.5 \%$ \\
\hline & Vanadium & $18.7 \%$ \\
\hline & Zinc & $12.7 \%$ \\
\hline
\end{tabular}

60 a Relative percent difference evaluation was not required for analytes not included in this table.

61 'The significance of relative percent difference values are discussed within the RSVP for the subject site.

$62 \mathrm{QAVC}=$ quality assurance/quality control

63 RSVP $=$ remaining sites verification package 
Washington Closure Hanford

$\underset{\text { Originator M. J. Appel Wh Wft }}{\text { Project }}$ Subject 100-F Area Field Remediation
CALCULATION SHEET
Job No. $\frac{05 / 30 / 06}{14655}$
Calc. No. 0100 -CA-Vo251
Checked T. M. Blakley 1 m

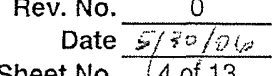

\begin{tabular}{|c|c|c|c|c|c|c|c|c|c|c|c|c|c|c|c|c|c|c|c|c|c|c|c|c|c|c|}
\hline \multirow{2}{*}{\begin{tabular}{|c|c|}
2 & Sampling \\
4 & Area \\
\end{tabular}} & \multirow{2}{*}{$\begin{array}{c}\text { HEIS } \\
\text { Number } \\
1112 D 3 \\
\end{array}$} & \multirow{2}{*}{$\begin{array}{c}\begin{array}{c}\text { Sample } \\
\text { Date } \\
2 / 6 / 2006\end{array} \\
\end{array}$} & \multicolumn{3}{|c|}{ Arsenic } & \multicolumn{3}{|c|}{ Barium } & \multicolumn{3}{|c|}{ Beryllium } & \multicolumn{3}{|c|}{ Boron } & \multicolumn{3}{|c|}{ Cadmium } & \multicolumn{3}{|c|}{ Chromium (Total) } & \multicolumn{3}{|c|}{ Hexavalent Chromium } & \multicolumn{3}{|c|}{ Cobalt } \\
\hline & & & $\frac{\mathrm{mg} / \mathrm{kg}}{3.0}$ & $\left|\begin{array}{|l}a \\
c\end{array}\right|$ & $\frac{P Q L}{0.34}$ & $\frac{\mathrm{mg} / \mathrm{kg}}{80.8}$ & $Q$ & $\frac{P Q L}{0.06}$ & $\frac{\mathrm{mg} / \mathrm{kg}}{0.19}$ & Q & $\frac{P Q L}{0.02}$ & $\frac{\mathrm{mg} / \mathrm{kg}}{4.0}$ & \begin{tabular}{|l|l|} 
\\
\end{tabular} & $\frac{P Q L}{0.82}$ & $\frac{m g / k g}{0.36}$ & $\mid \begin{array}{l}\mid a \\
u J \\
u\end{array}$ & $\frac{P Q L}{0.36}$ & $\frac{\mathrm{mg} / \mathrm{kg}}{8.4}$ & Q & $\frac{P Q L}{0.49}$ & $\frac{\mathrm{mg} / \mathrm{kg}}{0.47}$ & $\begin{array}{ll}0 \\
\end{array}$ & $\frac{P Q L}{0.21}$ & $\frac{\mathrm{mg} / \mathrm{kg}}{4.8}$ & a & $\frac{\mathrm{PQ1}}{0.36}$ \\
\hline $\begin{array}{l}\text { Duplicate of } \\
\text { J112D3 }\end{array}$ & J112F3 & 2/6/2006 & 2.0 & us & 2.0 & 71.9 & & 0.06 & 0.12 & & 0.02 & 2.5 & & 0.81 & 0.70 & c & 0.21 & 7.1 & & 0.48 & 0.55 & & 0.21 & 4.2 & & 0.36 \\
\hline 2 & $\begin{array}{l}5112 D 4 \\
12\end{array}$ & $216 / 2006$ & 2.1 & $\mathrm{uJ}$ & 2.1 & 45.1 & & 0.06 & 0.14 & & 0.02 & 2.9 & & 0.81 & 0.60 & c & 0.21 & 9.3 & & 0.48 & 0.27 & & 0.21 & 4.5 & & 0.36 \\
\hline$\frac{3}{4}$ & $\frac{511205}{111106}$ & $\begin{array}{ll}2 / 6 / 2006 \\
2 / 62000\end{array}$ & $\frac{2.4}{18}$ & C & 0.36 & $\begin{array}{l}96.3 \\
9.78\end{array}$ & & 0.066 & 0.18 & & 0.02 & 3.9 & & 0.85 & 0.65 & C & 0.22 & 8.3 & & 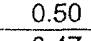 & 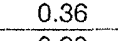 & & & 4.8 & & 0.38 \\
\hline-4 & $\begin{array}{l}\frac{J 11206}{J 11207} \\
\end{array}$ & $\frac{2 / 6 / 2006}{2 / 62006}$ & $\frac{1.8}{3.5}$ & Uu & 1.8 & 27.8 & & 0.06 & 0.09 & & 0.02 & 0.79 & $u$ & 0.79 & 0.33 & | & 0.33 & 8.2 & - & 0.47 & 0.20 & 10 & 0.20 & 3.5 & & 0.35 \\
\hline$\frac{5}{6}$ & $\begin{array}{l}\mathrm{J120/} \\
\mathrm{J11208}\end{array}$ & $\frac{26 / 1 / 2006}{2 / 62006}$ & $-\frac{3.5}{1.5}$ & $\left|\frac{c}{u j}\right|$ & $\frac{0.34}{15}$ & $\frac{93.7}{28.8}$ & & 0.06 & 0.15 & & $\begin{array}{l}0.02 \\
0.02\end{array}$ & 1.8 & 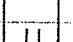 & 0.81 & 0.86 & $\left|\frac{C}{c}\right|$ & 0.21 & $\frac{10.7}{6.9}$ & 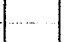 & 0.48 & 0.21 & $\frac{0}{11}$ & 0.21 & $\frac{4.5}{31}$ & & 0.36 \\
\hline 7 & J112D9 & $\frac{1 / 200}{2 / 6 / 2006}$ & 1.8 & $\mid$ & 1.8 & 33.7 & & 0.06 & 0.09 & & 0.02 & 0.80 & 10 & 0.009 & 0.51 & $\left|\frac{1}{c}\right|$ & 0.20 & 6 & & $\frac{0.47}{0.47}$ & $\frac{0.36}{0.36}$ & 4 & 0.21 & $\frac{1.1}{3.2}$ & & 0.36 \\
\hline 8 & $\sqrt{112 F 0}$ & $2 / 6 / 2006$ & 2.4 & \begin{tabular}{|c|}
$c$ \\
\end{tabular} & 0.33 & 64.6 & & 0.06 & 0.14 & & 0.02 & 2.4 & - & 0.79 & 0.60 & c & 0.20 & 8.3 & & 0.47 & 0.23 & & 0.21 & 4.4 & & 0.35 \\
\hline$\frac{9}{10}$ & $\begin{array}{l}J 12 F 1 \\
112 F 2\end{array}$ & $\frac{26 / 2006}{26006}$ & $\frac{4.8}{6.2}$ & $\frac{c}{c}$ & 0.34 & $\frac{61.3}{766}$ & & 0.06 & 0.15 & & 0.02 & $\frac{2.0}{24}$ & 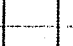 & 0.81 & 0.68 & C & -0.21 & 8.5 & & 8 & 0.2 & & 0.21 & 4.6 & & 0.36 \\
\hline & & & & & & & & & & & & & & 0.81 & & & 0.21 & 10.4 & & 0.48 & 0.21 & $U 1$ & 0.20 & $\begin{array}{l}4.8 \\
\end{array}$ & & 0.36 \\
\hline
\end{tabular}

16 Statistical Computation Input Data

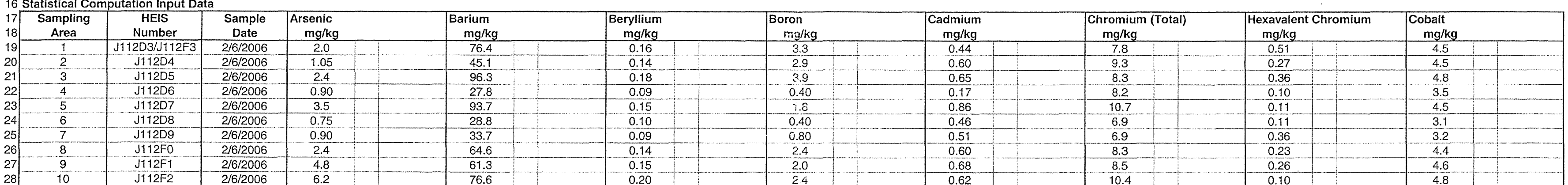

29 Statistical Computations

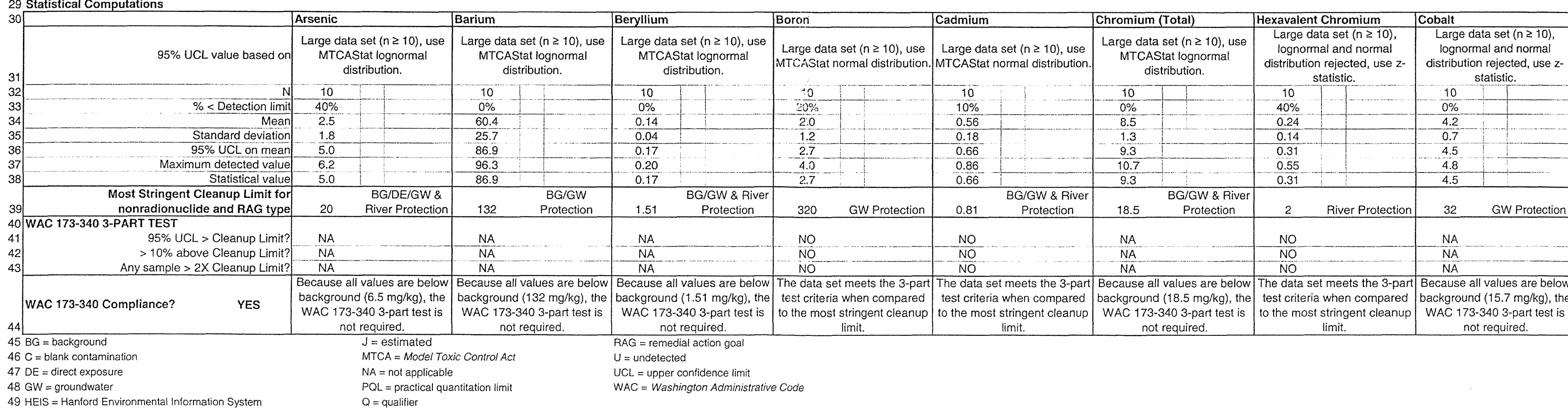


Originator M. J. Appel $M$ /fot

CALCULATION SHEE

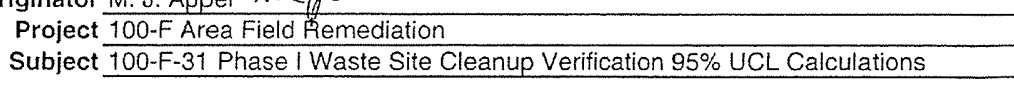

Date $\frac{05 / 30 / 06}{14655}$
Job No.

Calc. No. $\frac{0100 F-C A-V 0251}{1}$
Checked T.M. Blakley

Rev. No. $\frac{0}{\text { Date }}$
Sheet No. $\frac{5 / 30 / 49}{5 \text { of } 13}$

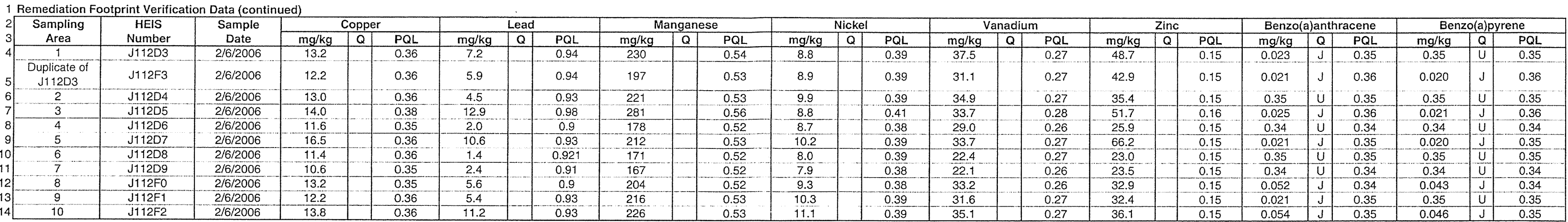

15 Statistical Computation Input Data

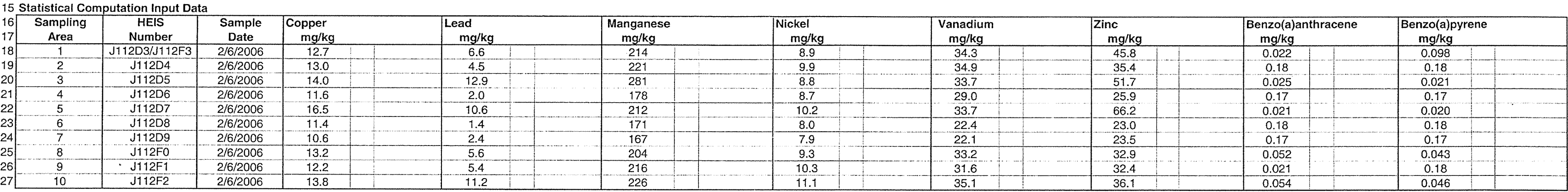

28 Statistical Computations

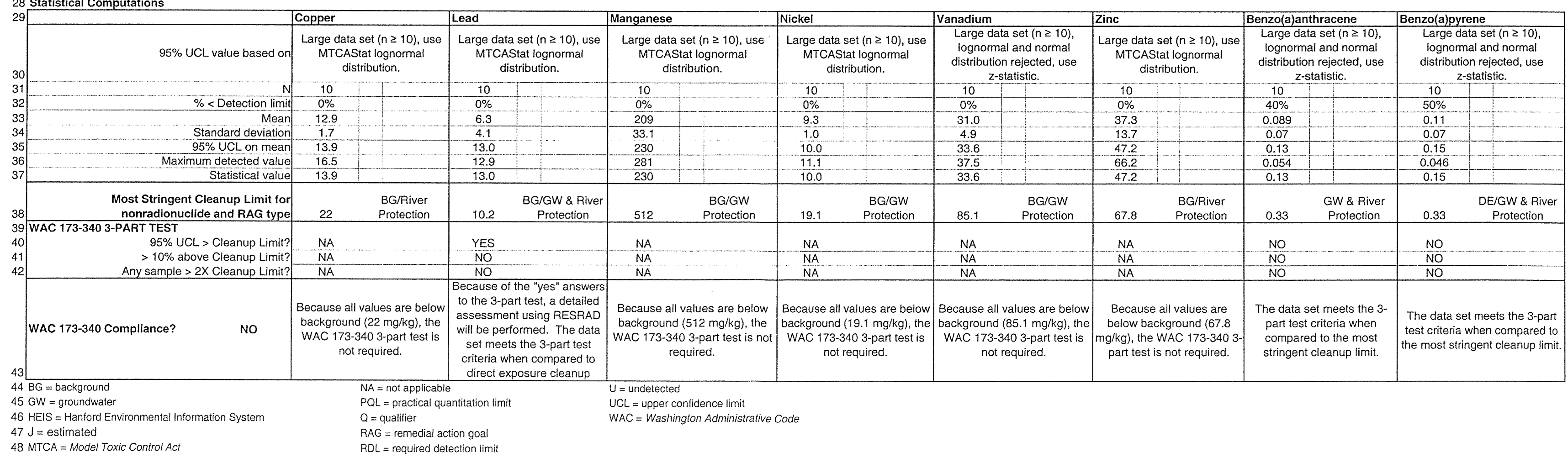


$\frac{\text { Washington Closure Hanford }}{\text { Originator M. J. Appel }}$

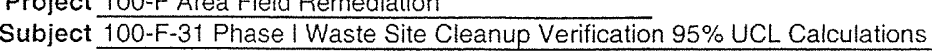

\begin{tabular}{|c|c|c|c|c|c|c|c|c|c|c|c|c|c|c|c|c|c|}
\hline \multirow{2}{*}{\begin{tabular}{|c|c|} 
Sampling \\
\end{tabular}} & \multirow{2}{*}{$\begin{array}{c}\text { HEIS } \\
\text { Number } \\
J 12 D 3\end{array}$} & \multirow{2}{*}{$\begin{array}{c}\begin{array}{c}\text { Sample } \\
\text { Date }\end{array} \\
2 / 6 / 2006\end{array}$} & \multicolumn{3}{|c|}{ Benzo(b)fluoranthene } & \multicolumn{3}{|c|}{ Benzo(k)fluoranthene } & \multicolumn{3}{|c|}{$\begin{array}{c}\text { Chrysene } \\
\text { malka }\end{array}$} & \multicolumn{3}{|c|}{$\begin{array}{l}\text { Fluoranthene } \\
\text { glkg }\end{array}$} & \multicolumn{3}{|c|}{ Pyrene } \\
\hline & & & $\frac{\frac{m g / k g}{0.35}}{0.03}$ & $\mid$\begin{tabular}{|c|c|} 
\\
$u$ \\
\end{tabular} & $\frac{P Q 2}{0.35}$ & $\frac{\mathrm{mg} / \mathrm{kg}}{0.35}$ & $\frac{a}{U}$ & $\frac{P Q L}{0.35}$ & $\frac{\mathrm{mg} \mathrm{gkg}}{0.033}$ & $\frac{d}{J}$ & $\frac{P Q L}{0.35}$ & $\frac{\mathrm{mg} \mathrm{gkg}}{0.040}$ & & $\frac{P Q L}{0.35}$ & $\frac{\mathrm{mg} \mathrm{gkg}}{0.049}$ & $\mid \begin{array}{l}\mid a \\
j \\
\end{array}$ & $\frac{P Q L}{0.35}$ \\
\hline $\begin{array}{l}\text { Duplicat } \\
\text { J1122 }\end{array}$ & $\mathrm{J112F3}$ & $2 / 6$ & 0.021 & J & 0.3 & & $J$ & 0.36 & 0.032 & & 0.36 & 0.038 & J & 0.3 & 0.057 & J & 0.36 \\
\hline & & & $\frac{0.3}{0.02}$ & $\frac{u}{J}$ & 0 & 0.022 & $\frac{\pi}{U}$ & $\frac{0.3}{0.5}$ & $\frac{0.023}{0.037}$ & & 0. & 0.024 & $\mathrm{~J}$ & & 0.030 & 3 & 0.35 \\
\hline & & & 0.34 & 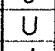 & 0.34 & 0.34 & $u$ & 0 & & 11 & 0. & 0.34 & $\underline{u}$ & 0 & & $\underline{u}$ & 0.34 \\
\hline$\frac{5}{6}$ & $\frac{511.2}{J 11}$ & & 0.018 & $\frac{1}{11}$ & 0.35 & 0.021 & $\frac{11}{3}$ & & $\frac{0.030}{0.35}$ & 11 & 0 & 0 & & 0 & 0.6 & 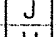 & 0.35 \\
\hline & & & 0. & & 0. & & & & & & & & & & & & 0.35 \\
\hline & & & & & & & J & & & & & & & & & & 0.044 \\
\hline & & & & u & & & & & 0.028 & & & & & & & & 5 \\
\hline 10 & $J 112 F 2$ & $2 / 6 / 2$ & 0.04 & $\mathrm{~J}$ & 0.35 & 0.0 & & & 0.065 & & 0.35 & 0.08 & $\mathrm{~J}$ & 0.3 & 0.11 & & 0.35 \\
\hline
\end{tabular}

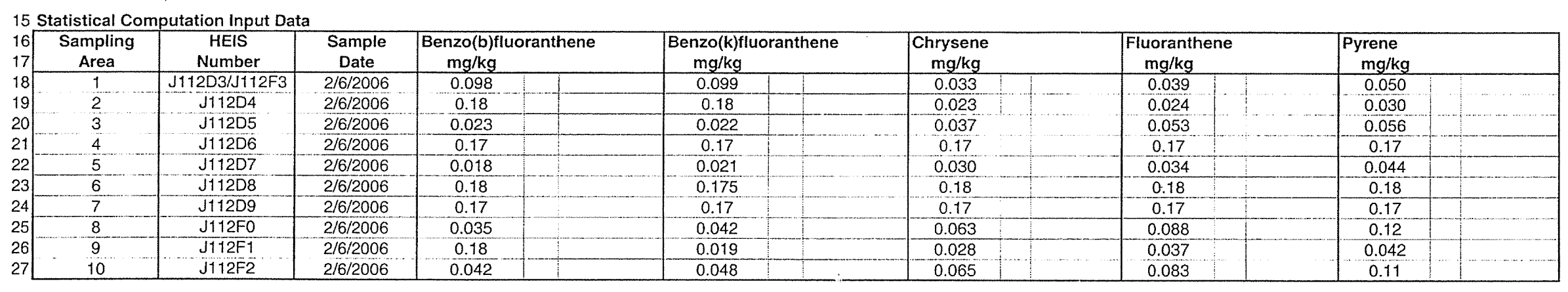

28 Statistical Computations

\begin{tabular}{|c|c|c|c|c|c|}
\hline & Benzo(b)fluoranthene & Benzo(k)fluoranthene & Chrysene & Fluoranthene & Pyrene \\
\hline $95 \%$ UCL value based on & $\begin{array}{l}\text { Large data set }(n \geq 10), \\
\text { lognormal and normal } \\
\text { distribution rejected, use } \\
z \text {-statistic. }\end{array}$ & $\begin{array}{l}\text { Large data set }(n \geq 10), \\
\text { lognomal and nomal } \\
\text { distribution rejected, !se } \\
\text { - }- \text {-statistific. } \\
\end{array}$ & $\begin{array}{l}\text { Large data set }(n \geq 10) \text {, } \\
\text { lognormal and normal } \\
\text { distribution rejected, use } \\
z \text {-statistic. }\end{array}$ & $\begin{array}{l}\text { Large data set ( } n \geq 10 \text { ), use } \\
\text { MTCAStat lognormal } \\
\text { distribution. }\end{array}$ & $\begin{array}{l}\text { Large data set }(n \geq 10) \text {, use } \\
\text { MTCAStat lognoormal } \\
\text { distribution. }\end{array}$ \\
\hline$\%<$ Detection limit & & $10 \quad T \quad I$ & 10 & 10 & 10 \\
\hline$\frac{\%<\text { Detection lilit }}{\text { Mean }}$ & & $\frac{40 \%}{0.094}$ & $\begin{array}{l}30 \% \\
0.079\end{array}$ & $30 \%$ & $30 \%$ \\
\hline Standard deviation & 0.07 & 0.071 & 0.065 & 年 & $\frac{0.059}{0.059}$ \\
\hline $95 \%$ UCL on mean & & 0.13 & & 0.17 & \\
\hline Maximum detected value & 0.042 & 0.048 & 0.065 & 0.088 & $\frac{0.16}{0.12}$ \\
\hline 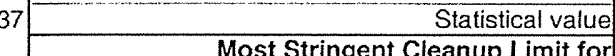 & 0.15 & 0.13 & 0.11 & 0.17 & 0.18 \\
\hline $\begin{array}{l}\text { Most Stringent Cleanup Limit tor } \\
\text { nonradionuclide and RAG type }\end{array}$ & $\begin{array}{l}\text { GW \& R iviver } \\
\text { Protection }\end{array}$ & $\begin{array}{l}\text { GW \& River } \\
\text { Protection }\end{array}$ & $\begin{array}{l}\text { River } \\
\text { Protection }\end{array}$ & $\begin{array}{l}\text { River } \\
\text { Protection }\end{array}$ & GW Protection \\
\hline $\begin{array}{l}309 \\
40\end{array}$ & & NO & & & \\
\hline $\begin{array}{l}>10 \% \text { above Cleanup Limit? } \\
\text { Ans sample }>2 \times \text { C Cleanuu Limit? }\end{array}$ & NO & $\begin{array}{l}\text { NO } \\
\text { NO }\end{array}$ & NO & NO & NO \\
\hline WAC 173-340 Compliance? & $\begin{array}{l}\text { The data set meets the 3-part } \\
\text { test triteria when compared to } \\
\text { the most stringent cleanup limit. }\end{array}$ & $\begin{array}{l}\text { The datat set meets the 3-part } \\
\text { test } \\
\text { the mosteria when compared to } \\
\text { the mingent cleanup limit }\end{array}$ & $\begin{array}{l}\text { The data set meets the } 3- \\
\text { part test criteria when } \\
\text { compared to the most } \\
\text { stringent cleanup limit. }\end{array}$ & $\begin{array}{l}\text { The data set meets the 3- } \\
\text { part test criteria when } \\
\text { compared to the most } \\
\text { stringent cleanup limit. }\end{array}$ & \begin{tabular}{|c|} 
The data set meets the $3-$ \\
part test criteria when \\
compared to the most \\
stringent cleanup limit.
\end{tabular} \\
\hline $\begin{array}{l}44 \mathrm{GW}=\text { groundwater } \\
45 \mathrm{HEIS}=\text { Hantord Environmental Information System } \\
46 \mathrm{~J}=\text { stimanted }\end{array}$ & $\begin{array}{l}P Q L=\text { practical qua } \\
Q=\text { qualifie } \\
\text { PAG = remedial act }\end{array}$ & $\begin{array}{l}U=\text { =ndetecte } \\
U C L=\text { upper } \\
W A C=\text { Wash }\end{array}$ & & & \\
\hline
\end{tabular}


Washington Closure Hanford

Originator M. J. Appel MV

CALCULATION SHEET

Project 100 -F Area Field Remediation Subject 100-F-31 Phase I Waste Site Cleanup Verification 95\% UCL Calculations

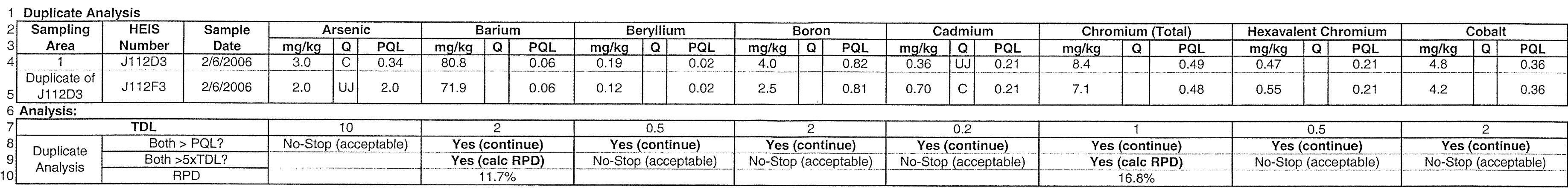

\begin{tabular}{|c|c|c|c|c|c|c|c|c|c|c|c|c|c|c|c|c|c|c|c|c|c|c|c|c|c|}
\hline \multirow{2}{*}{$\begin{array}{c}\text { Sampling } \\
\text { Area }\end{array}$} & \multirow{3}{*}{$\begin{array}{c}\text { HEIS } \\
\text { Number } \\
\text { J112D3 }\end{array}$} & \multirow{3}{*}{$\begin{array}{c}\text { Sample } \\
\text { Date } \\
2 / 6 / 2006\end{array}$} & \multicolumn{3}{|c|}{ Copper } & \multicolumn{3}{|c|}{ Lead } & \multicolumn{3}{|c|}{ Manganese } & \multicolumn{2}{|c|}{ Nickel } & \multicolumn{3}{|c|}{ Vanadium } & \multicolumn{3}{|c|}{ Zinc } & \multicolumn{3}{|c|}{ Benzo(a)anthracene } & \multicolumn{3}{|c|}{ Benzo(a)pyrene } \\
\hline & & & $\mathrm{mg} / \mathrm{kg}$ & $Q$ & $\overline{P Q L}$ & $\mathrm{mg} / \mathrm{kg}$ & \begin{tabular}{|l|l|l|}
$Q$ & \\
\end{tabular} & $\mathrm{PQL}$ & $\mathrm{mg} / \mathrm{kg}$ & Q & $\mathrm{PQL}$ & $\mathrm{mg} / \mathrm{kg}$ & \begin{tabular}{|l|l|}
$Q$ & $P Q L$ \\
\end{tabular} & $\mathrm{mg} / \mathrm{kg}$ & Q & $\mathrm{PQL}$ & $\mathrm{mg} / \mathrm{kg}$ & Q & $\mathrm{PQL}$ & $\mathrm{mg} / \mathrm{kg}$ & $Q$ & $\mathrm{PQL}$ & & & $\mathrm{PQL}$ \\
\hline \multirow{2}{*}{$\begin{array}{l}\frac{1}{\text { Duplicate of }} \\
\mathrm{J} 112 \mathrm{D} 3\end{array}$} & & & 13.2 & & 0.36 & 7.2 & & 0.94 & 230 & & 0.54 & 8.8 & 0.39 & 37.5 & & 0.27 & 48.7 & & 0.15 & 0.023 & $\mathrm{~J}$ & 0.35 & 0.35 & & 0.35 \\
\hline & J112F3 & 2/6/2006 & 12.2 & & 0.36 & 5.9 & & 0.94 & 197 & & 0.53 & 8.9 & 0.39 & 31.1 & & 0.27 & 42.9 & & 0.15 & 0.021 & $\mathrm{~J}$ & 0.36 & 0.02 & 子 & 0.36 \\
\hline \multicolumn{26}{|l|}{ Analysis: } \\
\hline \multicolumn{3}{|c|}{$\frac{\pi}{n}$} & \multicolumn{3}{|c|}{ (continue) } & \multicolumn{3}{|c|}{$\frac{5}{5 \text { (continue) }}$} & \multicolumn{3}{|c|}{ Yes (continue) } & \multicolumn{2}{|c|}{ Yes (cor } & \multicolumn{3}{|c|}{$\frac{2.5}{\text { Yes (continue) }}$} & \multicolumn{3}{|c|}{ (continue) } & \multicolumn{3}{|c|}{$\begin{array}{c}0.33 \\
\end{array}$} & \multicolumn{3}{|c|}{0.33} \\
\hline \multirow{2}{*}{$\begin{array}{l}\text { Duplicate } \\
\text { Analysis }\end{array}$} & \multicolumn{2}{|r|}{$\frac{\text { TL? }}{\text { TDL? }}$} & \multicolumn{3}{|c|}{ (calc RPD) } & \multirow{2}{*}{\multicolumn{3}{|c|}{ No-Stop (acceptable) }} & \multicolumn{3}{|c|}{ Yes (calc RPD) } & \multirow{2}{*}{\multicolumn{2}{|c|}{ No-Stop (acceptable) }} & \multicolumn{3}{|c|}{$\begin{array}{l}\text { Yes (calc RPD) } \\
\text { Yes (calc }\end{array}$} & \multicolumn{3}{|c|}{$\begin{array}{l}\text { Yes (conthue) } \\
\text { Yes (calc RPD) }\end{array}$} & \multicolumn{3}{|c|}{ No-Stop (acceptable) } & \multicolumn{3}{|c|}{ No-Stop (acceptable) } \\
\hline & & & & 7.9\% & & & & & & $15.5 \%$ & & & & & $8.7 \%$ & & & $2.7 \%$ & & & & & & & \\
\hline
\end{tabular}

\begin{tabular}{|c|c|c|c|c|c|c|c|c|c|c|c|c|c|c|c|c|c|}
\hline \multirow{3}{*}{\begin{tabular}{|c|}
$\begin{array}{c}\text { Sampling } \\
\text { Area }\end{array}$ \\
1 \\
\end{tabular}} & \multirow{3}{*}{$\begin{array}{c}\text { HEIS } \\
\text { Number } \\
J 112 D 3\end{array}$} & \multirow{2}{*}{$\begin{array}{c}\text { Sample } \\
\text { Date }\end{array}$} & \multicolumn{3}{|c|}{ Benzo(b)fluoranthene } & \multicolumn{3}{|c|}{ Benzo(k)fluoranthene } & \multicolumn{3}{|c|}{ Chrysene } & \multicolumn{3}{|c|}{ Fluoranthene } & \multicolumn{3}{|c|}{ Pyrene } \\
\hline & & & $\mathrm{mg} / \mathrm{kg}$ & $\mathbf{Q}$ & $P Q L$ & $\mathrm{mg} / \mathrm{kg}$ & $Q$ & $\mathrm{PQL}$ & $\mathrm{mg} / \mathrm{kg}$ & $a$ & $\mathrm{PQL}$ & $\mathrm{mg} / \mathrm{kg}$ & Q & $\mathrm{PQL}$ & $\mathrm{mg} / \mathrm{kg}$ & Q & $P Q L$ \\
\hline & & & 0.35 & $u$ & 0.35 & 0.35 & U & 0.35 & 0.033 & J & 0.35 & 0.04 & J & 0.35 & 0.049 & $\mathrm{~J}$ & 0.35 \\
\hline $\begin{array}{l}\text { Duplicate of } \\
\text { J112D3 }\end{array}$ & J112F3 & 2/6/2006 & 0.021 & J & 0.36 & 0.023 & 1 & 0.36 & 0.032 & $\mathrm{~J}$ & 0.36 & 0.038 & .1 & 0.36 & 0.051 & $\mathrm{~J}$ & 0.36 \\
\hline
\end{tabular}

26 Analysis:

\begin{tabular}{|c|c|c|c|c|c|c|}
\hline \multirow{3}{*}{\begin{tabular}{l|l}
8 & Duplicate \\
9 & Analysis
\end{tabular}} & TDL & \multirow{2}{*}{$\begin{array}{c}0.33 \\
\text { No-Stop (acceptable) }\end{array}$} & \multirow{2}{*}{$\frac{0.33}{\text { No-Stop (acceptable) }}$} & \multirow{2}{*}{$\begin{array}{c}0.33 \\
\text { No-Stop (acceptable) }\end{array}$} & \multirow{2}{*}{$\frac{0.33}{\text { No-Stop (acceptable) }}$} & \multirow{3}{*}{$\begin{array}{c}0.33 \\
\text { No-Stop (acceptable) }\end{array}$} \\
\hline & Both > PQL? & & & & & \\
\hline & Both >5xTDL? & & & & & \\
\hline
\end{tabular}

$33 \mathrm{HEL}=$ = prantical Envirol quantitition limit

$34 \mathrm{Q}=$ qualifier

relative percent difference

et detection lim 


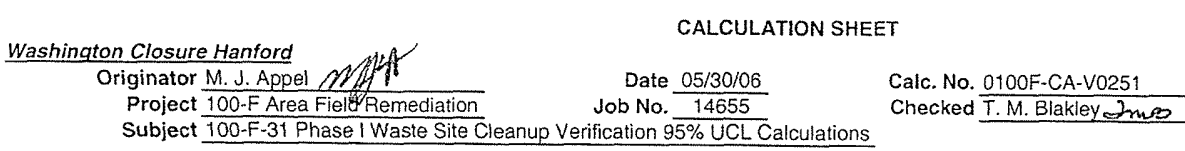

Rev. No. $\frac{0}{\text { Date }} 5 / 20 / 0$

Ecology Software (MTCAStat) Results

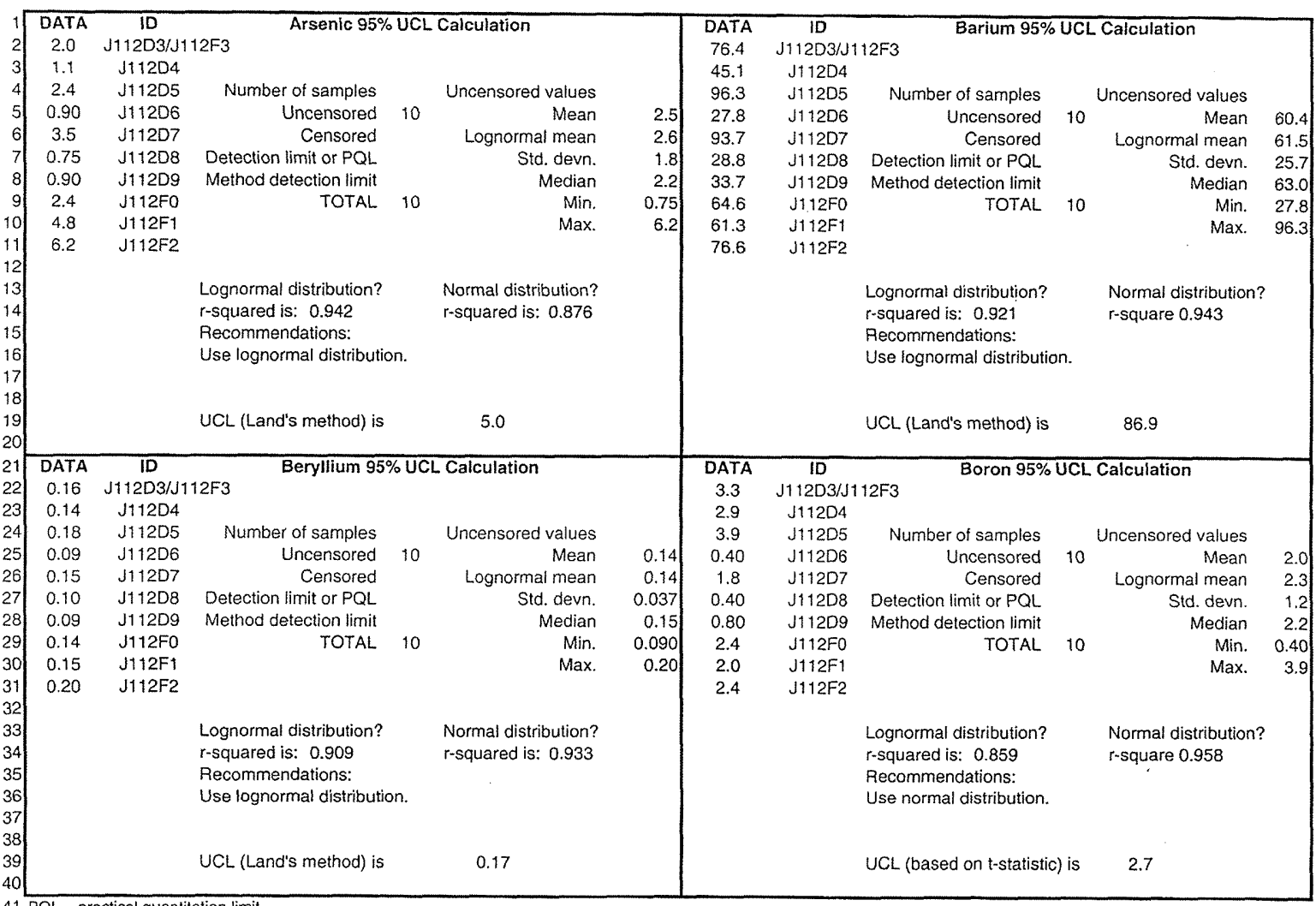

actical quantitation limi

$42 \mathrm{UCL}=$ upper confidence limit 


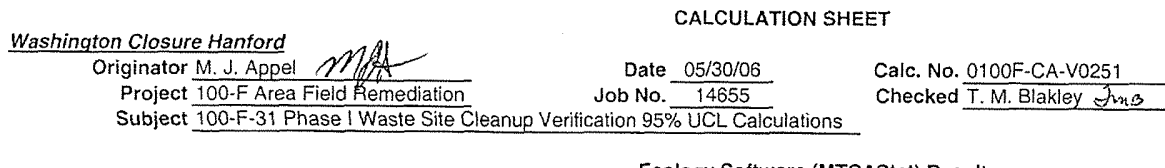

Ecology Software (MTCAStat) Results

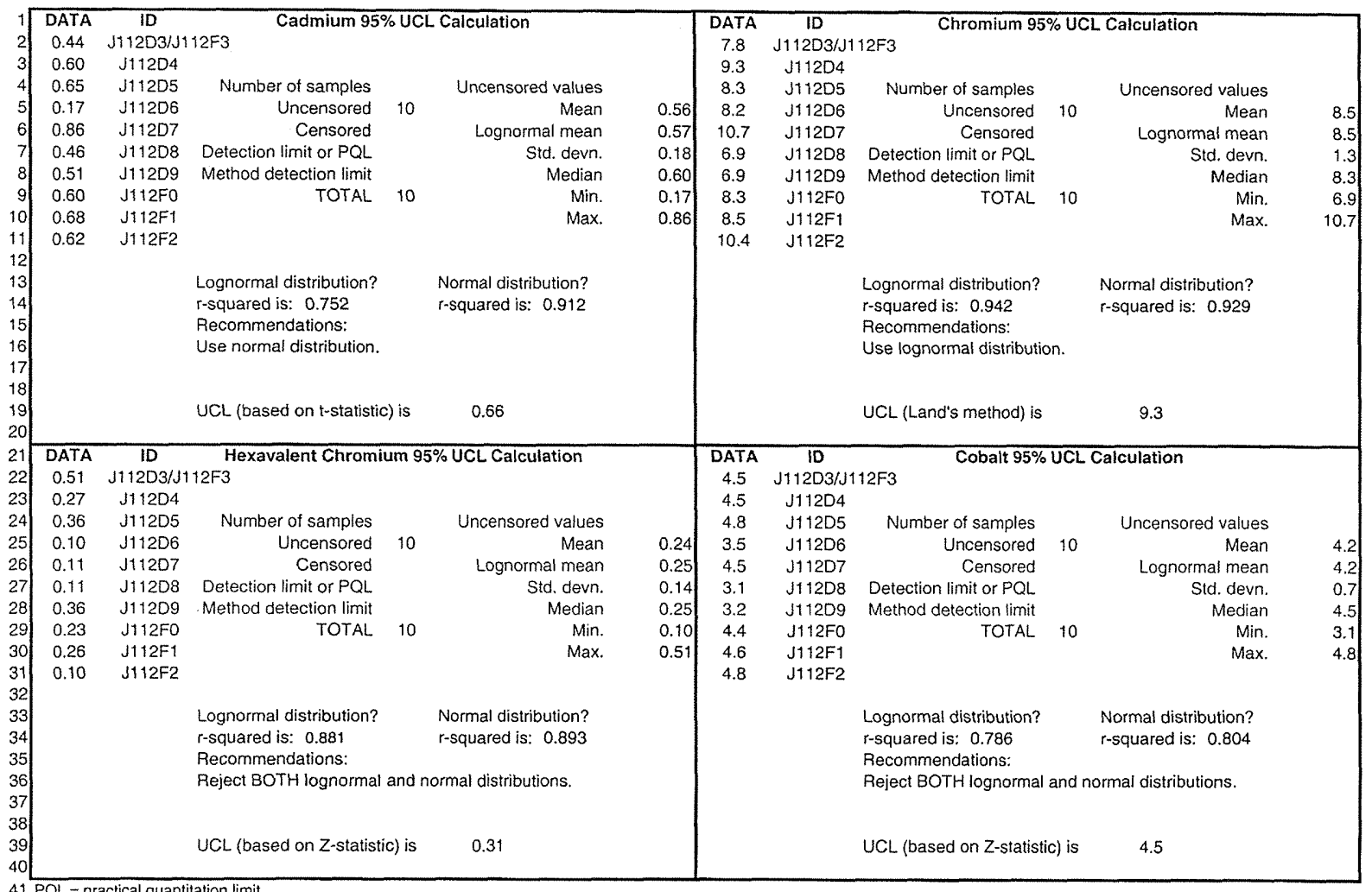

$42 \mathrm{UCL}=$ upper confidence limit 


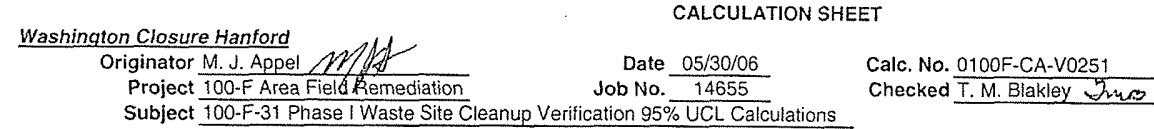
Project $\frac{100-F \text { Area Field Remediation }}{100-F-31 \text { Phase I Waste Site Cleanup Verification } 95 \% \text { UCL Calculations }}$ Checked T. M. Blakley Jumo

Ecology Software (MTCAStat) Results

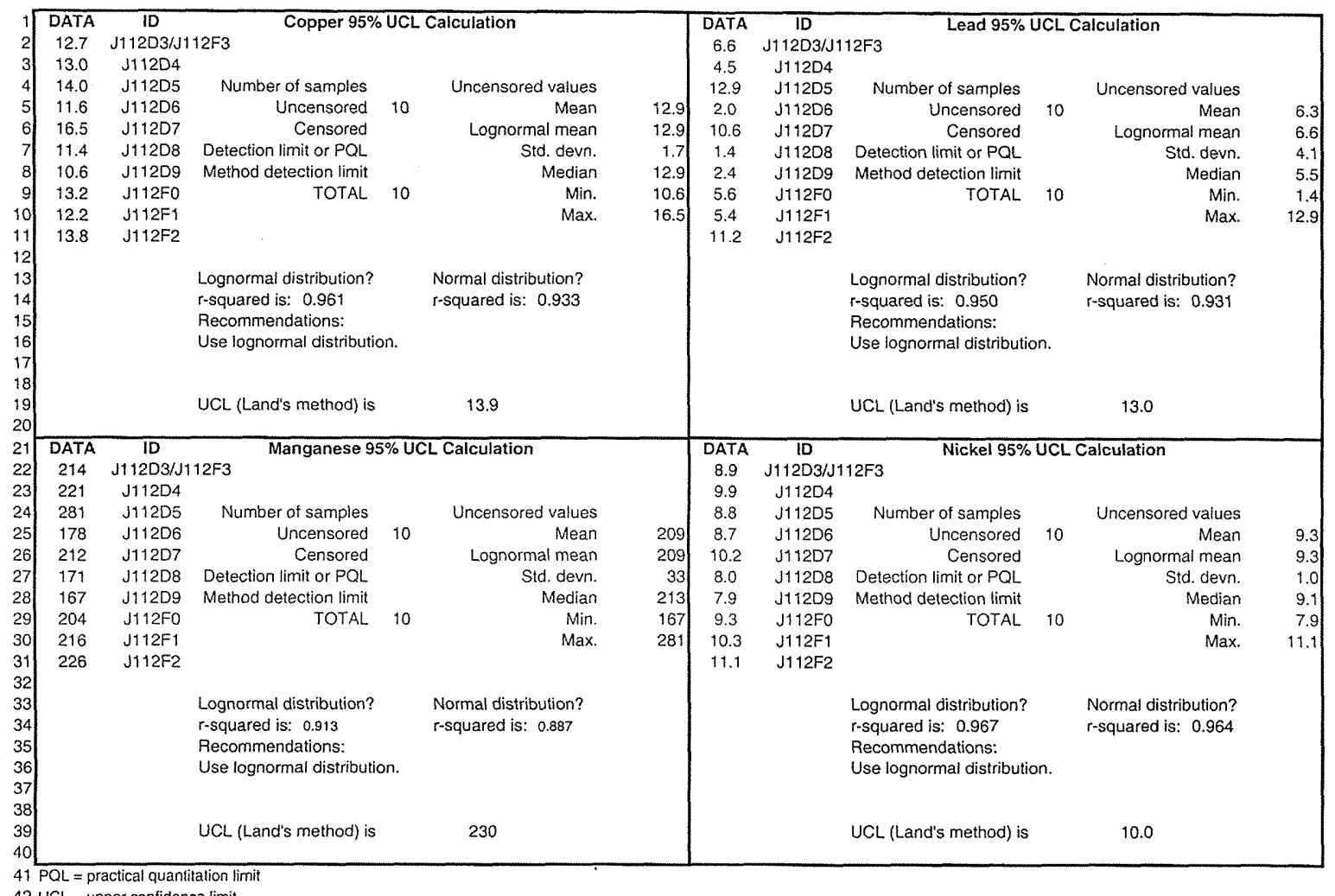



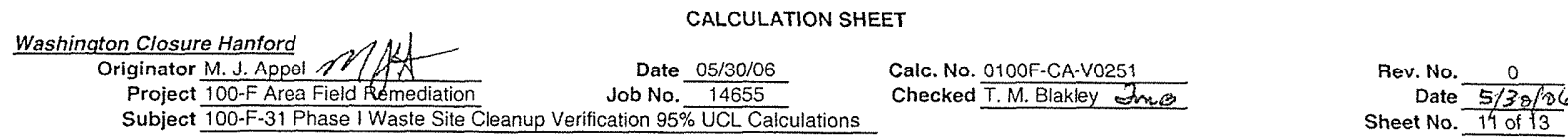

Ecology Software (MTCAStat) Results

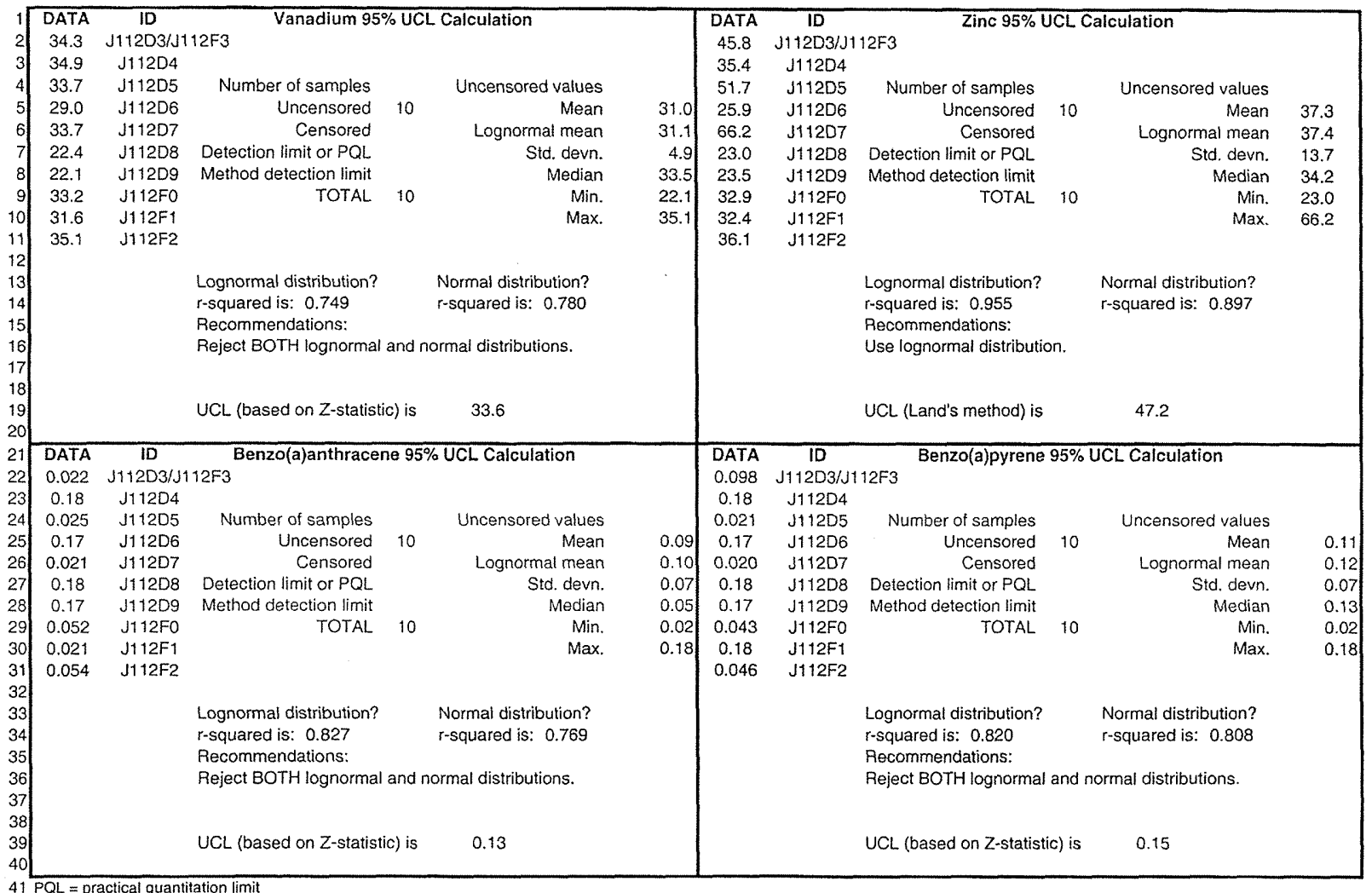

UCL = upper conficence limit 
CALCULATION SHEET

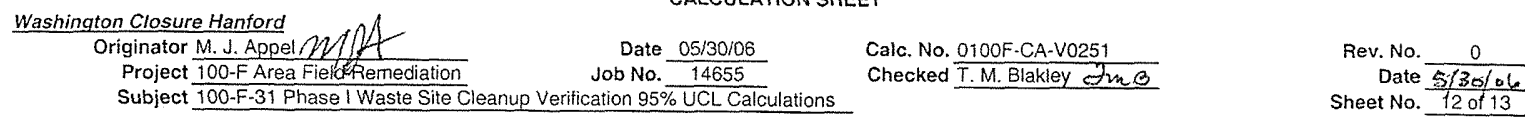

Ecology Software (MTCAStat) Results

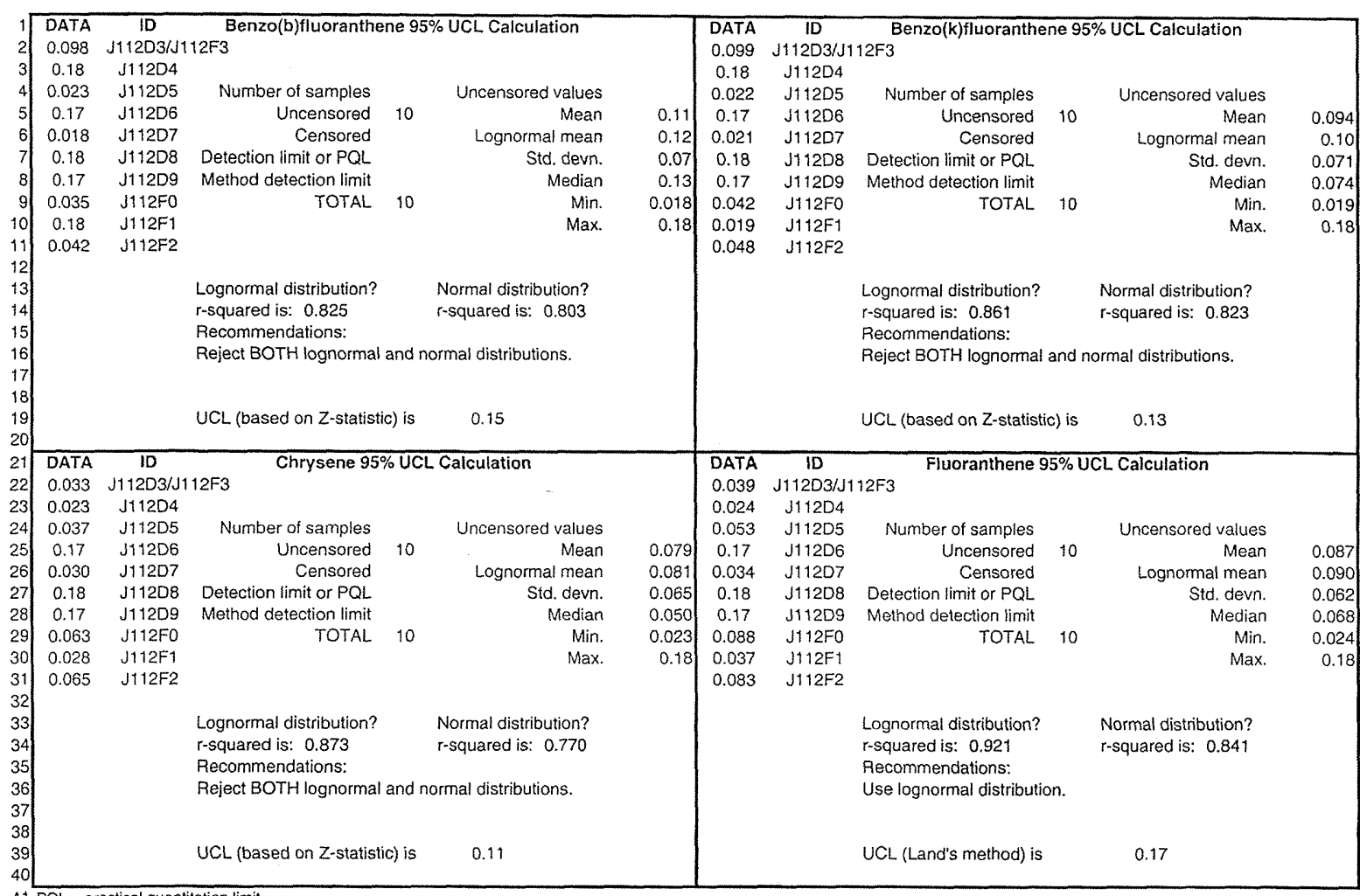




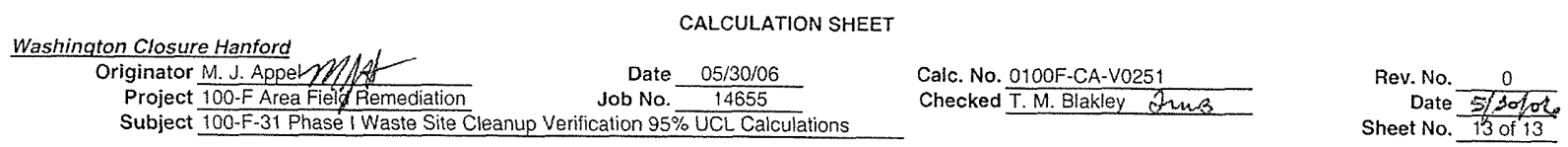

Ecology Software (MTCAStat) Results

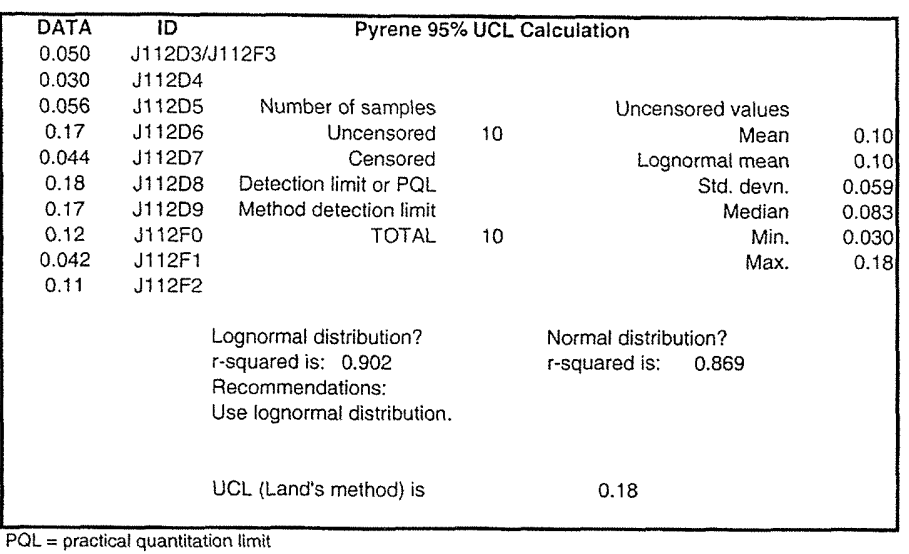


Attachment 1. 100-F-31 Verification Sampling Results.

\begin{tabular}{|c|c|c|c|c|c|c|c|c|c|c|c|c|c|c|c|c|c|c|c|c|c|c|c|}
\hline \multirow{2}{*}{$\begin{array}{l}\text { Sample } \\
\text { Lacation }\end{array}$} & \multirow{2}{*}{$\begin{array}{c}\text { HEIS } \\
\text { Number }\end{array}$} & \multirow{2}{*}{$\begin{array}{c}\text { Sample } \\
\text { Date }\end{array}$} & \multicolumn{3}{|c|}{ Americium-241 } & \multicolumn{3}{|c|}{ Cesium-137 } & \multicolumn{3}{|c|}{ Cobalt-60 } & \multicolumn{3}{|c|}{ Europium-152 } & \multicolumn{3}{|c|}{ Europium1-154 } & \multicolumn{3}{|c|}{ Europium-155 } & \multicolumn{3}{|c|}{ Potassium-40 } \\
\hline & & & $\mathrm{pCi} / \mathrm{g}$ & $Q$ & $\mathrm{MDA}$ & pCig & $Q$ & $\mathrm{MDA}$ & $\mathrm{pClg}$ & $Q$ & $\mathrm{MDA}$ & $p C i / g$ & Q] & MDA & $\mathrm{pCi} / \mathrm{g}$ & 0 & $\mathrm{MDA}$ & $\mathrm{pCl} / \mathrm{g}$ & Q & $\mathrm{MDA}$ & $\mathrm{pCi} / \mathrm{g}$ & 0 & $\mathrm{MDA}$ \\
\hline$\frac{1}{\text { Diplicale of }}$ & $\mathrm{J112D3}$ & 26606 & 0.33 & u & 0.33 & 0.17 & 0 & 0.17 & 0.18 & $\mathrm{U}$ & 0.18 & 0.55 & U & 0.55 & 0.59 & $\mathrm{U}$ & 0.59 & 0.36 & uा & 0.36 & 9.48 & & 1.6 \\
\hline $1112 \mathrm{D} 3$ & $3+215$ & $2 / 6 / 06$ & 0.31 & $u$ & 0.31 & 0.17 & 0 & 0.17 & 0.17 & u & 0.17 & 0.48 & $\mathrm{u}$ & 0.48 & 0.55 & u & 0.5 .5 & 0.34 & $u$ & 0.34 & 9.53 & & औ. \\
\hline 2 & $1112 \mathrm{D} 4$ & $2 / 606$ & 0.33 & $\bar{U}$ & 0.33 & 0.002 & 0 & 0,092 & 0.11 & $\mathrm{U}$ & 0.11 & 0.22 & 4 & 0.22 & 0.32 & 0 & 0.32 & 0.26 & $\mathrm{U}$ & 0.26 & 14.0 & & 12 \\
\hline 3 & 111205 & $2 / 6 / 66$ & 0.36 & $\mathrm{U}$ & 0.36 & 0.18 & U & 0.18 & 0.15 & U & 0.13 & 0.25 & 0 & 0.25 & 0.30 & 0 & 0.30 & 0.27 & 0 & 0.27 & 16.0 & 11 & 16 \\
\hline 4 & $J 112 D 6$ & $2 / 6 / 106$ & 0.27 & $\mathrm{u}$ & 0.27 & 0.12 & 0 & 0.12 & 0.12 & $\mathrm{U}$ & 0.12 & 0.29 & u & 0.29 & 0.38 & $\bar{v}$ & 0.38 & $\overline{0.24}$ & 0 & 0.24 & 15.4 & & 0.93 \\
\hline 5 & 111207 & $26 / 106$ & 0.46 & $\mathrm{u}$ & 0.46 & 011 & 0 & 0.11 & 0.10 & $\mathrm{U}$ & 0.10 & 0.27 & 0 & 0.27 & 0.34 & $\mathrm{v}$ & 0.34 & 0.23 & 4 & 0.23 & 13.7 & & 0.87 \\
\hline 6 & 511208 & $2 / 6 \% 66$ & 0.28 & U & 0.28 & 0.14 & $\mathrm{u}$ & 0.14 & 0.16 & $\mathrm{u}$ & 0.16 & 0,40 & 0 & 0,40 & 0.52 & $\overline{\mathrm{U}}$ & 0.52 & 0.28 & U & 0.28 & 11.3 & & 1.0 \\
\hline 7 & 511209 & 36606 & 0.33 & u & 0.33 & 0.089 & U & 0.089 & 0.12 & $\mathrm{U}$ & 0.12 & 0.21 & U & 0.21 & 0.32 & $\mathrm{U}$ & 0.32 & 0.25 & 0 & 0.25 & 11.8 & & 0.83 \\
\hline 8 & $\$ 11250$ & $2 / 6106$ & 0.30 & $\mathrm{u}$ & 0.30 & 0.09 & U & 0,09 & 0.10 & u & 0.10 & 0.2 & 0 & 0.2 & 0.27 & v & 0.27 & 0.23 & U & 0.23 & 16.0 & $\mathrm{u}$ & 16,0 \\
\hline 9 & J112FI & $2 / 606$ & 0.50 & $\mathrm{u}$ & 0.30 & 0.13 & U & 0.13 & 0.094 & U & 0.094 & 034 & 0 & 0.34 & 0.46 & 0 & 0.46 & 0.26 & $\mathrm{U}$ & 0.26 & 14.1 & & 1.4 \\
\hline 10 & $1112 \% 2$ & $2 / 606$ & 0.47 & $\bar{U}$ & 0.47 & 0.12 & U & 0.12 & 0.095 & U & 0,095 & 0.28 & U) & 0.28 & 0.36 & U & 0.36 & 0.26 & 0 & 0.26 & 13.6 & & 1 \\
\hline
\end{tabular}

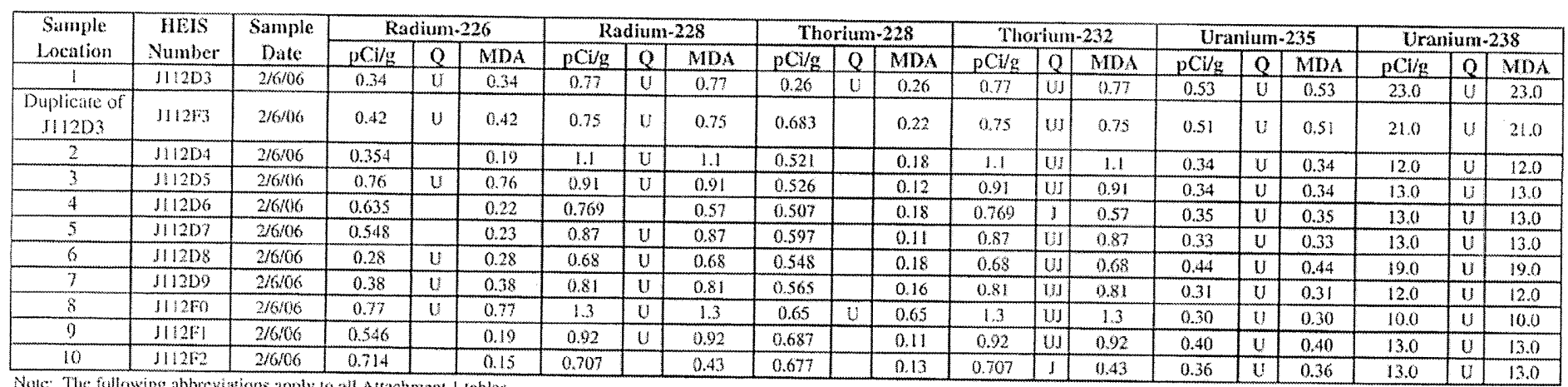

Nolc: The following abbrevations apply to all Attactment I (ables.

Note: Data caulified with $C, D$, andor $J$ are considered acceptable valuas

$C$ ablank contunination (inorganic constituents)

$\mathrm{PQL}=$ practical quantitation limit

D) $=$ thituted

Hels = Honford Enviromental Information Sysen $\quad$ U w wndeteced

$J=$ stimated

MDA a thininum detciblable ativity 
Attachment 1. 100-F-31 Verification Sampling Results.

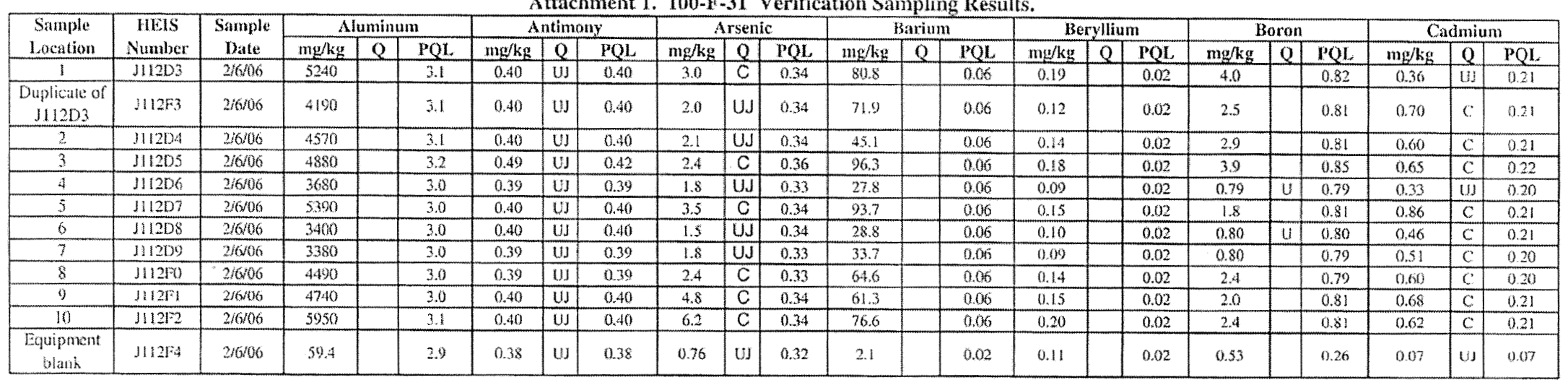

\begin{tabular}{|c|c|c|c|c|c|c|c|c|c|c|c|c|c|c|c|c|c|c|c|c|c|c|c|}
\hline \multirow{2}{*}{$\begin{array}{c}\text { Sample } \\
\text { Location }\end{array}$} & \multirow{2}{*}{$\begin{array}{c}\text { IIEIS } \\
\text { Number }\end{array}$} & \multirow{2}{*}{$\begin{array}{l}\text { Sample } \\
\text { Date }\end{array}$} & \multicolumn{3}{|c|}{ Cakcium } & \multicolumn{3}{|c|}{ Chromium (Total) } & \multicolumn{3}{|c|}{ Cobalt } & \multicolumn{3}{|c|}{ Copper } & \multicolumn{3}{|c|}{$\begin{array}{l}\text { Hexavalent } \\
\text { Chromium }\end{array}$} & \multicolumn{3}{|c|}{ Iron } & \multicolumn{3}{|c|}{ Lead } \\
\hline & & & $\mathrm{mg} / \mathrm{kg}$ & 9 & PQL & $\mathrm{my} / \mathrm{kg}$ & $Q$ & $\mathrm{PQL}$ & $\mathrm{mg} / \mathrm{kg}^{\mathrm{g}}$ & $Q$ & $\mathrm{PQL}$ & $\mathrm{mg} / \mathrm{kg}$ & $Q$ & $\mathrm{POL}$ & $\mathrm{mg} / \mathrm{kg}$ & $Q$ & $\mathrm{PQL}$ & $\mathrm{mg} / \mathrm{kg}$ & $Q$ & $\mathrm{PQL}$ & $\mathrm{mg} / \mathrm{kg}$ & $Q$ & $\mathrm{PQL}$ \\
\hline 1 & $\mathrm{J11203}$ & $236 / 06$ & 4400 & & 3.6 & 8.4 & & 0.49 & 4.8 & & 0.36 & 13.2 & & 0.36 & 0,47 & & 0.21 & 15700 & & 9.7 & 72 & & 0.94 \\
\hline $\begin{array}{c}\text { Duplicte of } \\
\text { 1112D3 }\end{array}$ & $\pi 1213$ & $2 / 6 / 106$ & 3750 & & 3.6 & 7.1 & & 0.48 & 4.2 & & 0.36 & 122 & & 0.36 & 0.55 & & 0.21 & 12100 & & 9.7 & 59 & & 0.94 \\
\hline 2 & 111204 & $2 / 6 / 106$ & 5230 & & 3.6 & 9.3 & & 0.48 & 4.5 & & 0.36 & 130 & & 0.36 & 0.27 & & 0.21 & 13600 & & 9.7 & 4.5 & & 0.93 \\
\hline 3 & 111205 & 22606 & 4830 & & 3.7 & 8.3 & & 0.50 & 4.8 & & 0.38 & 140 & & 0.38 & 0.36 & & 0.22 & 16700 & & 10.1 & 120 & & 098 \\
\hline 4 & 111206 & 26606 & 6270 & & 3.5 & 8.2 & & $0.4 ?$ & 3.5 & & 0.35 & 116 & & 1035 & 0.20 & 11 & 0.20 & 11600 & & 9.4 & 2.0 & & 0.90 \\
\hline 5 & 511207 & $2 / 6106$ & 5930 & & 3.6 & 10.7 & & 0.48 & 45 & & 0.36 & 66.5 & & 0.36 & 0.21 & U & 0.21 & 15100 & & 9.6 & 10.6 & & 0.93 \\
\hline 6 & J112D8 & 2606 & 5190 & & 3.5 & 6.9 & & 0.47 & 3.1 & & 0.36 & 11.4 & & 0.36 & 0.21 & U & 0.21 & 9460 & & 9.5 & 1.4 & & 0.921 \\
\hline 7 & 111209 & $2 / 6106$ & 3500 & & 3.5 & 6.9 & & 0.47 & 32 & & 0.35 & 10.6 & & 0.35 & 0.36 & & 0.21 & 9440 & & 9.4 & 2.4 & & 0.91 \\
\hline 9 & $\mathrm{J112F1}$ & $2 / 61606$ & 4290 & & 3.6 & 8.5 & & 0.48 & 4.6 & & 0.36 & 12.2 & & 0.36 & 026 & & $0.2 !$ & 1.3600 & & 9.6 & 5.4 & & 0,93 \\
\hline 11) & $5112 \mathrm{F2}$ & 216106 & 4140 & & 3.6 & 10.4 & & 0.48 & 4.8 & & 0.36 & 13.8 & & 0.36 & 0.21 & U & 0.20 & 16100 & & 9.7 & 11.2 & & 0.93 \\
\hline $\begin{array}{c}\text { Gqupment } \\
\text { blank }\end{array}$ & $\mathrm{Ji} 2 \mathrm{FA}$ & $2 / 6066$ & 27.2 & & 1.1 & 0.15 & u & 0.15 & 0.11 & $u$ & 0.11 & 0.25 & & 0.11 & & & & 577 & & 31 & 0.37 & & 0.3 \\
\hline
\end{tabular}


Attachment 1. 100-F-31 Verification Sampling Results.

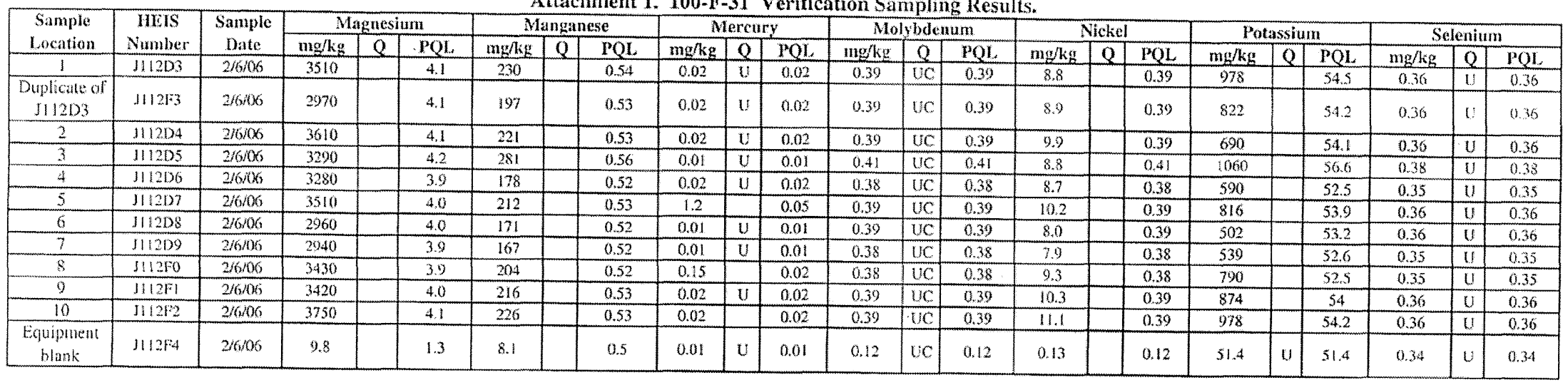

\begin{tabular}{|c|c|c|c|c|c|c|c|c|c|c|c|c|c|c|c|c|c|}
\hline \multirow{2}{*}{$\begin{array}{l}\text { Sample } \\
\text { Location } \\
\end{array}$} & \multirow{2}{*}{$\begin{array}{c}\text { HEIS } \\
\text { Number }\end{array}$} & \multirow{2}{*}{$\begin{array}{c}\text { Sample } \\
\text { Date }\end{array}$} & \multicolumn{3}{|c|}{ Silicon } & \multicolumn{3}{|c|}{ Silver } & \multicolumn{3}{|c|}{ Sodium } & \multicolumn{3}{|c|}{ Vonadium } & \multicolumn{3}{|c|}{ Zinc } \\
\hline & & & mp/kg & $Q$ & $\mathrm{PQL}$ & $\mathrm{mg} / \mathrm{kg}$ & Q & $\mathrm{PQL}$ & $\mathrm{mg} / \mathrm{kg}$ & $Q$ & POL & $\mathrm{mg} / \mathrm{kg}$ & Q & PQL & $\mathrm{mg} / \mathrm{kg}$ & $Q$ & $\mathrm{PQL}$ \\
\hline 1 & $1112 \mathrm{D} 3$ & $2 / 6006$ & 643 & 1 & 2.5 & 0.42 & 0 & 0.42 & 197 & C & 2.9 & 37.5 & & 0.27 & 48.7 & & 0.15 \\
\hline $\begin{array}{c}\text { Duplicute of } \\
\text { J112D3 }\end{array}$ & 11283 & $26 / 6106$ & 517 & J & 25 & 0.42 & u & 0.42 & 123 & c & 2.8 & 31,1 & & 0.27 & 42.9 & & 0.15 \\
\hline 2 & $\pi 1204$ & 26606 & 546 & $\mathrm{~J}$ & 2.5 & 0.42 & $u$ & 0,42 & 108 & $C$ & 2.8 & 34.9 & & 0.27 & 35.4 & & 0.15 \\
\hline 3 & 111205 & 28606 & 593 & 3 & 2.6 & 0.44 & 0 & 0.44 & 307 & $C$ & 3 & 33.7 & & 0.28 & 51.7 & & 0.16 \\
\hline 4 & 111206 & 26606 & 518 & 3 & 2.4 & 0.41 & 4 & 0.41 & 94,7 & C & 2.7 & 29.0 & & 0.26 & 25.9 & & 0.15 \\
\hline 5 & 111207 & 266006 & 549 & 3 & 2.5 & 0.42 & 0 & 0.42 & 122 & $\mathrm{C}$ & 2.8 & 33.7 & & 0.27 & 66.2 & & 0.15 \\
\hline 6 & 111208 & 26606 & 388 & 1 & 24 & 0.41 & 0 & 0.41 & 75.7 & $c$ & 2.8 & 22.4 & & 0.27 & 23.0 & & 0.15 \\
\hline 7 & $\triangle 11209$ & 26606 & 508 & 3 & 2.4 & 0.41 & U & 0.41 & 79.4 & $C$ & 2.7 & 22.1 & & 0.26 & 23.5 & & 0.15 \\
\hline 8 & $J 112 F 0$ & 26006 & 647 & $i$ & 2.4 & 0.41 & $\mathrm{u}$ & $0.4 !$ & 109 & $c$ & 2.7 & 33.2 & & 0.26 & 32.9 & & 0.15 \\
\hline 9 & $1112 \mathrm{FI}$ & 2,6606 & 707 & $J$ & 25 & 0.42 & u & 0.42 & 107 & c & 2.8 & 31.6 & & 0.27 & 32.4 & & 0.15 \\
\hline 10 & $1112 F 2$ & 26106 & 661 & 1 & 2.5 & 0.42 & $\mathrm{u}$ & 0.42 & 131 & $\mathrm{c}$ & 2.8 & 35.1 & & 0.27 & 36.1 & & 0.15 \\
\hline $\begin{array}{c}\text { Equipment } \\
\text { blank }\end{array}$ & $1112 F_{4}$ & 26606 & 49.5 & J & 0.78 & 0.13 & u & 0.13 & $n$ & (u) & 2.7 & 0.24 & & 0.09 & 2 & & 0.05 \\
\hline
\end{tabular}


Attachment 1. 100-F-31 Verification Sampling Results.

\begin{tabular}{|c|c|c|c|c|c|c|c|c|c|c|c|c|}
\hline \multirow[t]{2}{*}{ Constituent } & \multicolumn{3}{|c|}{$\begin{array}{c}\text { J112D3 } \\
\text { Sample Location } 1 \\
\text { Sample Date } 2 / 6 / 06 \\
\end{array}$} & \multicolumn{3}{|c|}{$\begin{array}{c}\text { J112F3 } \\
\text { Duplicate of J112D3 } \\
\text { Sample Date 2/6/06 } \\
\end{array}$} & \multicolumn{3}{|c|}{$\begin{array}{c}\text { J112D4 } \\
\text { Sample Location } 2 \\
\text { Sample Date } 2 / 6 / 06\end{array}$} & \multicolumn{3}{|c|}{$\begin{array}{c}\text { J112D5 } \\
\text { Sample Location } 3 \\
\text { Sample Date } 2 / 6 / 06\end{array}$} \\
\hline & $\mu \mathrm{g} / \mathrm{kg}$ & $Q$ & $\mathrm{PQL}$ & $\mu \mathrm{g} / \mathrm{kg}$ & $Q$ & $\mathrm{PQL}$ & $\mu \mathrm{g} / \mathrm{kg}$ & $Q$ & PQL & $\mu \mathrm{g} / \mathrm{kg}$ & $Q$ & PQL \\
\hline \multicolumn{13}{|c|}{ Polychlorinated Biphenyls } \\
\hline Aroclor-1016 & 14 & $\mathrm{U}$ & 14 & 14 & $\mathrm{U}$ & 14 & 14 & $\mathrm{U}$ & 14 & 15 & $\mathrm{U}$ & 15 \\
\hline Aroclor-1221 & 14 & $\mathrm{U}$ & 14 & 14 & $\mathrm{U}$ & 14 & 14 & $\mathrm{U}$ & 14 & 15 & $U$ & 15 \\
\hline Aroclor-1232 & 14 & $\mathrm{U}$ & 14 & 14 & $\mathrm{U}$ & 14 & 14 & $\mathrm{U}$ & 14 & 15 & $\mathrm{U}$ & 15 \\
\hline Aroclor-1242 & 14 & U & 14 & 14 & $\mathrm{U}$ & 14 & 14 & $\mathrm{U}$ & 14 & 15 & $\bar{U}$ & 15 \\
\hline Aroclor-1248 & 14 & $\mathrm{U}$ & 14 & 14 & U & 14 & 14 & $\mathrm{U}$ & 14 & 15 & $\mathrm{U}$ & 15 \\
\hline Aroclor-1254 & 14 & $\mathrm{U}$ & 14 & 14 & $\mathrm{U}$ & 14 & 14 & $\mathrm{U}$ & 14 & 15 & $\mathrm{U}$ & 15 \\
\hline Aroclor-1260 & 14 & $\mathrm{U}$ & 14 & 14 & $\mathrm{U}$ & 14 & 14 & $\mathrm{U}$ & 14 & 15 & $\mathrm{U}$ & 15 \\
\hline \multicolumn{13}{|c|}{ Semivolatile Organic Compounds } \\
\hline 1,2,4-Trichlorobenzene & 350 & UJ & 350 & 360 & UJ & 360 & 350 & UJ & 350 & 360 & UJ & 360 \\
\hline 1,2-Dichlorobenzene & 350 & $\mathrm{U}$ & 350 & 360 & $\mathrm{U}$ & 360 & 350 & U & 350 & 360 & $\mathrm{U}$ & 360 \\
\hline 1,3-Dichlorobenzene & 350 & U & 350 & 360 & $\mathrm{U}$ & 360 & 350 & $\mathrm{U}$ & 350 & 360 & $\mathrm{U}$ & 360 \\
\hline 1,4-Dichlorobenzene & 350 & $\mathrm{U}$ & 350 & 360 & $\mathrm{U}$ & 360 & 350 & $\mathrm{U}$ & 350 & 360 & $\mathrm{U}$ & 360 \\
\hline 2,4,5-Trichlorophenol & 880 & $\mathrm{U}$ & 880 & 890 & $\mathrm{U}$ & 890 & 880 & $U$ & 880 & 910 & $\mathrm{U}$ & 910 \\
\hline 2,4,6-Trichlorophenol & 350 & $\mathrm{U}$ & 350 & 360 & $\mathrm{U}$ & 360 & 350 & $\mathrm{U}$ & 350 & 360 & $\mathrm{U}$ & 360 \\
\hline 2,4-Dichlorophenol & 350 & $\mathrm{U}$ & 350 & 360 & $\mathrm{U}$ & 360 & 350 & $\mathrm{U}$ & 350 & 360 & $\mathrm{U}$ & 360 \\
\hline 2,4-Dimethylphenol & 350 & UJ & 350 & 360 & UI & 360 & 350 & US & 350 & 360 & $\mathrm{UJ}$ & 360 \\
\hline 2,4-Dinitrophenol & 880 & $\mathrm{U}$ & 880 & 890 & $\mathrm{U}$ & 890 & 880 & U & 880 & 910 & $\mathrm{U}$ & 910 \\
\hline 2,4-Dinitrotoluene & 350 & $\mathrm{U}$ & 350 & 360 & $\mathrm{U}$ & 360 & 350 & $\mathrm{U}$ & 350 & 360 & $\mathrm{U}$ & 360 \\
\hline 2,6-Dinitrotoluene & 350 & $\mathrm{U}$ & 350 & 360 & $\mathrm{U}$ & 360 & 350 & $\mathrm{U}$ & 350 & 360 & $\mathrm{U}$ & 360 \\
\hline 2-Chloronaphthalene & 350 & $\mathrm{U}$ & 350 & 360 & $\mathrm{U}$ & 360 & 350 & $\mathrm{U}$ & 350 & 360 & $\mathrm{U}$ & 360 \\
\hline 2-Chlorophenol & 350 & $\mathrm{U}$ & 350 & 360 & $\mathrm{U}$ & 360 & 350 & $\mathrm{U}$ & 350 & 360 & $\mathrm{U}$ & 360 \\
\hline 2-Methylnaphthalene & 350 & U & 350 & 360 & $\mathrm{U}$ & 360 & 350 & $\mathrm{U}$ & 350 & 360 & $\mathrm{U}$ & 360 \\
\hline 2-Methylphenol (cresol, o-) & 350 & $\mathrm{U}$ & 350 & 360 & $\mathrm{U}$ & 360 & 350 & $\mathrm{U}$ & 350 & 360 & U & 360 \\
\hline 2-Nitroaniline & 880 & $\mathrm{U}$ & 880 & 890 & $\mathrm{U}$ & 890 & 880 & $\mathrm{U}$ & 880 & 910 & $U$ & 910 \\
\hline 2-Nitrophenol & 350 & $\mathrm{U}$ & 350 & 360 & $\mathrm{U}$ & 360 & 350 & $\mathrm{U}$ & 350 & 360 & $\mathrm{U}$ & 360 \\
\hline 3,3'-Dichlorobenzidine & 350 & $\mathrm{U}$ & 350 & 360 & $\mathrm{U}$ & 360 & 350 & U & 350 & 360 & U & 360 \\
\hline 4-Methylphenol (p-cresol) & 350 & $\mathrm{U}$ & 350 & 360 & $\mathrm{U}$ & 360 & 350 & U & 350 & 360 & $\mathrm{U}$ & 360 \\
\hline 3-Nitroaniline & 880 & $\mathrm{U}$ & 880 & 890 & $\mathrm{U}$ & 890 & 880 & $\bar{U}$ & 880 & 910 & $\mathrm{U}$ & 910 \\
\hline 4,6-Dinitro-2-methylphenol & 880 & $\mathrm{U}$ & 880 & 890 & $\mathrm{U}$ & 890 & 880 & $\mathrm{U}$ & 880 & 910 & $\mathrm{U}$ & 910 \\
\hline 4-Bromophenyl-phenylether & 350 & $\mathrm{U}$ & 350 & 360 & $\mathrm{U}$ & 360 & 350 & $\mathrm{U}$ & 350 & 360 & $\mathrm{U}$ & 360 \\
\hline 4-Chloro-3-methylphenol & 350 & $\mathrm{U}$ & 350 & 360 & $\mathrm{U}$ & 360 & 350 & $\mathrm{U}$ & 350 & 360 & $\mathrm{U}$ & 360 \\
\hline 4-Chloroaniline & 350 & $\mathrm{U}$ & 350 & 360 & $\mathrm{U}$ & 360 & 350 & $\mathrm{U}$ & 350 & 360 & $\mathrm{U}$ & 360 \\
\hline 4-Chlorophenyl-phenylether & 350 & $\mathrm{U}$ & 350 & 360 & $\mathrm{U}$ & 360 & 350 & $\mathrm{U}$ & 350 & 360 & $\mathrm{U}$ & 360 \\
\hline 4-Nitroaniline & 880 & $\mathrm{U}$ & 880 & 890 & $U$ & 890 & 880 & $\mathrm{U}$ & 880 & 910 & $\mathrm{U}$ & 910 \\
\hline 4-Nitrophenol & 880 & U & 880 & 890 & $\mathrm{U}$ & 890 & 880 & $\mathrm{U}$ & 880 & 910 & $\mathrm{U}$ & 910 \\
\hline Acenaphthene & 350 & $\mathrm{U}$ & 350 & 360 & $\mathrm{U}$ & 360 & 350 & $\mathrm{U}$ & 350 & 360 & $\mathrm{U}$ & 360 \\
\hline Acenaphthylene & 350 & $\mathrm{U}$ & 350 & 360 & $\mathrm{U}$ & 360 & 350 & $\mathrm{U}$ & 350 & 360 & $\mathrm{U}$ & 360 \\
\hline Anthracene & 350 & $\mathrm{U}$ & 350 & 360 & $\mathrm{U}$ & 360 & 350 & $\mathrm{U}$ & 350 & 360 & $\mathrm{U}$ & 360 \\
\hline Benzo(a)anthracene & 23 & $J$ & 350 & 21 & $\mathrm{~J}$ & 360 & 350 & U & 350 & 25 & $\mathrm{~J}$ & 360 \\
\hline Benzo(a)pyrene & 350 & $\mathrm{U}$ & 350 & 20 & $\mathrm{~J}$ & 360 & 350 & $\mathrm{U}$ & 350 & 21 & $\mathrm{~J}$ & 360 \\
\hline Benzo(b)fluoranthene & 350 & $\mathrm{U}$ & 350 & 21 & $\mathrm{~J}$ & 360 & 350 & $\mathrm{U}$ & 350 & 23 & $\mathrm{~J}$ & 360 \\
\hline Benzo $(\mathrm{g}, \mathrm{h}, \mathrm{i})$ perylene & 350 & $\mathrm{U}$ & 350 & 360 & $\mathrm{U}$ & 360 & 350 & $\mathrm{U}$ & 350 & 360 & $\mathrm{U}$ & 360 \\
\hline Benzo(k)fluoranthene & 350 & $\mathrm{U}$ & 350 & 23 & $\mathrm{~J}$ & 360 & 350 & $\mathrm{U}$ & 350 & 22 & $J$ & 360 \\
\hline bis(2-Chloro-1-methylethyl)ether & 350 & $\mathrm{U}$ & 350 & 360 & $\mathrm{U}$ & 360 & 350 & $\mathrm{U}$ & 350 & 360 & U & 360 \\
\hline bis(2-Chloroethoxy)methane & 350 & $\mathrm{U}$ & 350 & 360 & $\mathrm{U}$ & 360 & 350 & $U$ & 350 & 360 & $\mathrm{U}$ & 360 \\
\hline bis(2-Chloroethyl) ether & 350 & U & 350 & 360 & $\mathrm{U}$ & 360 & 350 & $\mathrm{U}$ & 350 & 360 & $\mathrm{U}$ & 360 \\
\hline bis(2-Ethylhexyl) phthalate & 660 & $\mathrm{U}$ & 660 & 660 & $\mathrm{U}$ & 660 & 660 & $U$ & 660 & 660 & $\mathrm{U}$ & 660 \\
\hline
\end{tabular}

\begin{tabular}{llr} 
Attachment & \multicolumn{1}{c}{ Sheet No. } & 4 of 9 \\
\cline { 2 - 2 } Originator & Date & M.J/30/06 \\
Checked & D. Appel & Date \\
Calc. No. & T.Mlakley & Rev. No.
\end{tabular}


Attachment 1. 100-F-31 Verification Sampling Results.

\begin{tabular}{|c|c|c|c|c|c|c|c|c|c|c|c|c|}
\hline \multirow[t]{2}{*}{ Constituent } & \multicolumn{3}{|c|}{$\begin{array}{c}\text { J112D3 } \\
\text { Sample Location } 1 \\
\text { Sample Date } 2 / 6 / 06 \\
\end{array}$} & \multicolumn{3}{|c|}{$\begin{array}{c}\text { J112F3 } \\
\text { Duplicate of J112D3 } \\
\text { Sample Date } 2 / 6 / 06 \\
\end{array}$} & \multicolumn{3}{|c|}{$\begin{array}{c}\text { J112D4 } \\
\text { Sample Location } 2 \\
\text { Sample Date 2/6/06 }\end{array}$} & \multicolumn{3}{|c|}{$\begin{array}{c}\text { J112D5 } \\
\text { Sample Location } 3 \\
\text { Sample Date } 2 / 6 / 06 \\
\end{array}$} \\
\hline & $\mu \mathrm{g} / \mathrm{kg}$ & $Q$ & $\mathrm{PQL}$ & $\mu \mathrm{g} / \mathrm{kg}$ & $Q$ & PQL & $\mu \mathrm{g} / \mathrm{kg}$ & $Q$ & PQL & $\mu \mathrm{g} / \mathrm{kg}$ & $Q$ & PQL \\
\hline \multicolumn{13}{|c|}{ Senivolatile Organic Compounds (continued) } \\
\hline Butylbenzylphthalate & 350 & $\mathrm{U}$ & 350 & 360 & U & 360 & 350 & $\mathrm{U}$ & 350 & 360 & U & 360 \\
\hline Carbazole & 350 & $U$ & 350 & 360 & $\mathrm{U}$ & 360 & 350 & $\mathrm{U}$ & 350 & 360 & $\mathrm{U}$ & 360 \\
\hline Chrysene & 33 & $\mathrm{~J}$ & 350 & 32 & $\mathrm{~J}$ & 360 & 23. & $\mathrm{~J}$ & 350 & 37 & $\mathrm{~J}$ & 360 \\
\hline Dibenz $(\mathrm{a}, \mathrm{h})$ anthracene & 350 & $U$ & 350 & 360 & $\mathrm{U}$ & 360 & 350 & $\mathrm{U}$ & 350 & 360 & $\mathrm{U}$ & 360 \\
\hline Dibenzofuran & 350 & $\mathrm{U}$ & 350 & 360 & $\mathrm{U}$ & 360 & 350 & $\mathrm{U}$ & 350 & 360 & $\mathrm{U}$ & 360 \\
\hline Diethylphthalate & 350 & $\mathrm{U}$ & 350 & 360 & U & 360 & 350 & $\mathrm{U}$ & 350 & 360 & $\mathrm{U}$ & 360 \\
\hline Dimethylphthalate & 350 & $\mathrm{U}$ & 350 & 360 & $\mathrm{U}$ & 360 & 350 & $\mathrm{U}$ & 350 & 360 & $\mathrm{U}$ & 360 \\
\hline Di-n-butylphthalate & 350 & $\mathrm{U}$ & 350 & 660 & $\mathrm{U}$ & 660 & 660 & $\mathrm{U}$ & 660 & 660 & $\mathrm{U}$ & 660 \\
\hline Di-n-octylphthalate & 350 & $\mathrm{U}$ & 350 & 360 & $\mathrm{U}$ & 360 & 350 & $\mathrm{U}$ & 350 & 360 & $\mathrm{U}$ & 360 \\
\hline Fluoranthene & 40 & $\mathrm{~J}$ & 350 & 38 & $\mathrm{~J}$ & 360 & 24 & $\mathrm{~J}$ & 350 & 53 & $\mathrm{~J}$ & 360 \\
\hline Fluorene & 350 & $\mathrm{U}$ & 350 & 360 & $\mathrm{U}$ & 360 & 350 & $U$ & 350 & 360 & $\mathrm{U}$ & 360 \\
\hline Hexachlorobenzene & 350 & $\mathrm{U}$ & 350 & 360 & $\mathrm{U}$ & 360 & 350 & $\mathrm{U}$ & 350 & 360 & $\mathrm{U}$ & 360 \\
\hline Hexachlorobutadiene & 350 & $U$ & 350 & 360 & $\mathrm{U}$ & 360 & 350 & $\mathrm{U}$ & 350 & 360 & $U$ & 360 \\
\hline Hexachlorocyclopentadiene & 350 & $\mathrm{U}$ & 350 & 360 & $\mathrm{U}$ & 360 & 350 & $\mathrm{U}$ & 350 & 360 & U & 360 \\
\hline Hexachloroethane & 350 & $\mathrm{U}$ & 350 & 360 & $\mathrm{U}$ & 360 & 350 & $\mathrm{U}$ & 350 & 360 & $\mathrm{U}$ & 360 \\
\hline Indeno( $1,2,3-c d)$ pyrene & 350 & $\mathrm{U}$ & 350 & 360 & $\mathrm{U}$ & 360 & 350 & $\mathrm{U}$ & 350 & 360 & U & 360 \\
\hline Isophorone & 350 & $\mathrm{U}$ & 350 & 360 & $\mathrm{U}$ & 360 & 350 & $\mathrm{U}$ & 350 & 360 & $\mathrm{U}$ & 360 \\
\hline Naphthalene & 350 & $\mathrm{U}$ & 350 & 360 & $\mathrm{U}$ & 360 & 350 & $\mathrm{U}$ & 350 & 360 & $\mathrm{U}$ & 360 \\
\hline Nitrobenzene & 350 & $\mathrm{U}$ & 350 & 360 & $\mathrm{U}$ & 360 & 350 & $\mathrm{U}$ & 350 & 360 & $\mathrm{U}$ & 360 \\
\hline N-Nitroso-di-n-dipropylamine & 350 & $\mathrm{U}$ & 350 & 360 & $\mathrm{U}$ & 360 & 350 & $\mathrm{U}$ & 350 & 360 & $\mathrm{U}$ & 360 \\
\hline N-Nitrosodiphenylamine & 350 & $\mathrm{U}$ & 350 & 360 & $\mathrm{U}$ & 360 & 350 & $\mathrm{U}$ & 350 & 360 & $\mathrm{U}$ & 360 \\
\hline Pentachlorophenol & 880 & $\mathrm{U}$ & 880 & 890 & U & 890 & 880 & $\mathrm{U}$ & 880 & 910 & $U$ & 910 \\
\hline Phenanthrene & 20 & $J$ & 350 & 21 & $\mathrm{~J}$ & 360 & 350 & $\mathrm{U}$ & 350 & 27 & $\mathrm{~J}$ & 360 \\
\hline Phenol & 350 & $\mathrm{U}$ & 350 & 360 & $\mathrm{U}$ & 360 & 350 & $\mathrm{U}$ & 350 & 360 & U & 360 \\
\hline Pyrene & 49 & $J$ & 350 & 51 & $J$ & 360 & 30 & $\mathrm{~J}$ & 350 & 56 & $\mathrm{~J}$ & 360 \\
\hline
\end{tabular}

\begin{tabular}{|c|c|}
\hline Attachment & 1 \\
\hline Originator & M. J. Appel \\
\hline Checked & T. M. Blakley \\
\hline Calc. No. & $0100 \mathrm{~F}-\mathrm{CA}-\mathrm{V} 0251$ \\
\hline
\end{tabular}

Attachment

Checked

Calc. No.
Sheet No. $\frac{5 \text { of } 9}{05 / 30 / 06}$
Date
Date
Rev. No. 
Attachment 1. 100-F-31 Verification Sampling Results.

\begin{tabular}{|c|c|c|c|c|c|c|c|c|c|c|c|c|}
\hline \multirow[t]{2}{*}{ Constituent } & \multicolumn{3}{|c|}{$\begin{array}{c}\text { J112D6 } \\
\text { Sample Location } 4 \\
\text { Sample Date 2/6/06 } \\
\end{array}$} & \multicolumn{3}{|c|}{$\begin{array}{c}J 112 \mathrm{D} 7 \\
\text { Sample Location } 5 \\
\text { Sample Date } 2 / 6 / 06 \\
\end{array}$} & \multicolumn{3}{|c|}{$\begin{array}{c}\text { J112D8 } \\
\text { Sample Location } 6 \\
\text { Sample Date } 2 / 6 / 06 \\
\end{array}$} & \multicolumn{3}{|c|}{$\begin{array}{c}\text { J112D9 } \\
\text { Sample Location } 7 \\
\text { Sample Date } 2 / 6 / 06\end{array}$} \\
\hline & $\mu \mathrm{g} / \mathrm{kg}$ & $Q$ & $\mathrm{PQL}$ & $\mu \mathrm{g} / \mathrm{kg}$ & $Q$ & PQL & $\mu \mathrm{g} / \mathrm{kg}$ & $Q$ & PQL & $\mu \mathrm{g} / \mathrm{kg}$ & Q & PQL \\
\hline \multicolumn{13}{|c|}{ Polychlorinated Biphenyls } \\
\hline Aroclor-1016 & 14 & $\mathrm{U}$ & 14 & 14 & $\mathrm{U}$ & 14 & 14 & $\mathrm{U}$ & 14 & 14 & $\mathrm{U}$ & 14 \\
\hline Aroclor-1221 & 14 & $\mathrm{U}$ & 14 & 14 & $\mathrm{U}$ & 14 & 14 & $\mathrm{U}$ & 14 & 14 & $\mathrm{U}$ & 14 \\
\hline Aroclor-1232 & 14 & $\mathrm{U}$ & 14 & 14 & $\mathrm{U}$ & 14 & 14 & $\mathrm{U}$ & 14 & 14 & $\mathrm{U}$ & 14 \\
\hline Aroclor-1242 & 14 & $U$ & 14 & 14 & $\mathrm{U}$ & 14 & 14 & $\mathrm{U}$ & 14 & 14 & $\mathrm{U}$ & 14 \\
\hline Aroclor-1248 & 14 & $\mathrm{U}$ & 14 & 14 & $\mathrm{U}$ & 14 & 14 & $\mathrm{U}$ & 14 & 14 & $\mathrm{U}$ & 14 \\
\hline Aroclor-1254 & 14 & $\mathrm{U}$ & 14 & 71 & $\mathrm{~J}$ & 14 & 14 & $\mathrm{U}$ & 14 & 14 & $\mathrm{U}$ & 14 \\
\hline Aroclor- 1260 & 14 & $\mathrm{U}$ & 14 & 14 & $U$ & 14 & 14 & $\mathrm{U}$ & 14 & 14 & $\mathrm{U}$ & 14 \\
\hline \multicolumn{13}{|c|}{ Semivolatile Organic Compounds } \\
\hline 1,2,4-Trichlorobenzene & 340 & UJ & 340 & 350 & UJ & 350 & 350 & UJ & 350 & 340 & UJ & 340 \\
\hline 1,2-Dichlorobenzene & 340 & $\mathrm{U}$ & 340 & 350 & $\mathrm{U}$ & 350 & 350 & $\mathrm{U}$ & 350 & 340 & $\mathrm{U}$ & 340 \\
\hline 1,3-Dichlorobenzene & 340 & $\mathrm{U}$ & 340 & 350 & $\mathrm{U}$ & 350 & 350 & $\mathrm{U}$ & 350 & 340 & $\mathrm{U}$ & 340 \\
\hline 1,4-Dichlorobenzene & 340 & $\mathrm{U}$ & 340 & 350 & $\mathrm{U}$ & 350 & 350 & $\mathrm{U}$ & 350 & 340 & $\mathrm{U}$ & 340 \\
\hline 2,4,5-Trichlorophenol & 850 & $\mathrm{U}$ & 850 & 870 & $\mathrm{U}$ & 870 & 860 & $\mathrm{U}$ & 860 & 860 & $\mathrm{U}$ & 860 \\
\hline 2,4,6-Trichlorophenol & 340 & $\mathrm{U}$ & 340 & 350 & $\mathrm{U}$ & 350 & 350 & $\mathrm{U}$ & 350 & 340 & $\mathrm{U}$ & 340 \\
\hline 2,4-Dichlorophenol & 340 & $\mathrm{U}$ & 340 & 350 & $\mathrm{U}$ & 350 & 350 & $\mathrm{U}$ & 350 & 340 & $\mathrm{U}$ & 340 \\
\hline 2,4-Dimethylphenol & 340 & UJ & 340 & 350 & UJ & 350 & 350 & UJ & 350 & 340 & UJ & 340 \\
\hline 2,4-Dinitrophenol & 850 & $\mathrm{U}$ & 850 & 870 & $\mathrm{U}$ & 870 & 860 & $\mathrm{U}$ & 860 & 860 & $\mathrm{U}$ & 860 \\
\hline 2,4-Dinitrotoluene & 340 & $\mathrm{U}$ & 340 & 350 & $\mathrm{U}$ & 350 & 350 & $\mathrm{U}$ & 350 & 340 & $\mathrm{U}$ & 340 \\
\hline 2,6-Dinitrotoluene & 340 & $\mathrm{U}$ & 340 & 350 & $\mathrm{U}$ & 350 & 350 & $\mathrm{U}$ & 350 & 340 & $\mathrm{U}$ & 340 \\
\hline 2-Chloronaphthalene & 340 & $\mathrm{U}$ & 340 & 350 & $\mathrm{U}$ & 350 & 350 & $\mathrm{U}$ & 350 & 340 & $\mathrm{U}$ & 340 \\
\hline 2-Chlorophenol & 340 & $\mathrm{U}$ & 340 & 350 & $\mathrm{U}$ & 350 & 350 & $\mathrm{U}$ & 350 & 340 & $\mathrm{U}$ & 340 \\
\hline 2-Methylnaphthalene & 340 & $\mathrm{U}$ & 340 & 350 & $U$ & 350 & 350 & $\mathrm{U}$ & 350 & 340 & $\mathrm{U}$ & 340 \\
\hline 2-Methylphenol (cresol, o-) & 340 & $\mathrm{U}$ & 340 & 350 & $\mathrm{U}$ & 350 & 350 & $\mathrm{U}$ & 350 & 340 & $\mathrm{U}$ & 340 \\
\hline 2-Nitroaniline & 850 & $\mathrm{U}$ & 850 & 870 & $\mathrm{U}$ & 870 & 860 & $U$ & 860 & 860 & $\mathrm{U}$ & 860 \\
\hline 2-Nitrophenol & 340 & $\mathrm{U}$ & 340 & 350 & $\mathrm{U}$ & 350 & 350 & $\mathrm{U}$ & 350 & 340 & $\mathrm{U}$ & 340 \\
\hline 3,3'-Dichlorobenzidine & 340 & $\mathrm{U}$ & 340 & 350 & $\mathrm{U}$ & 350 & 350 & $U$ & 350 & 340 & $\mathrm{U}$ & 340 \\
\hline 4-Methylphenol (p-cresol) & 340 & $\mathrm{U}$ & 340 & 350 & $\mathrm{U}$ & 350 & 350 & $\mathrm{U}$ & 350 & 340 & $\mathrm{U}$ & 340 \\
\hline 3-Nitroaniline & 850 & $\mathrm{U}$ & 850 & 870 & $\mathrm{U}$ & 870 & 860 & $\mathrm{U}$ & 860 & 860 & $\mathrm{U}$ & 860 \\
\hline 4,6-Dinitro-2-methylphenol & 850 & $\mathrm{U}$ & 850 & 870 & $\mathrm{U}$ & 870 & 860 & $\mathrm{U}$ & 860 & 860 & $\mathrm{U}$ & 860 \\
\hline 4-Bromophenyl-phenylether & 340 & $\mathrm{U}$ & 340 & 350 & $\mathrm{U}$ & 350 & 350 & $\mathrm{U}$ & 350 & 340 & $\mathrm{U}$ & 340 \\
\hline 4-Chloro-3-methylphenol & 340 & $\bar{U}$ & 340 & 350 & $\mathrm{U}$ & 350 & 350 & $\mathrm{U}$ & 350 & 340 & $\mathrm{U}$ & 340 \\
\hline 4-Chloroaniline & 340 & $\mathrm{U}$ & 340 & 350 & $\mathrm{U}$ & 350 & 350 & $\mathrm{U}$ & 350 & 340 & $\mathrm{U}$ & 340 \\
\hline 4-Chlorophenyl-phenylether & 340 & $\mathrm{U}$ & 340 & 350 & $\mathrm{U}$ & 350 & 350 & $\mathrm{U}$ & 350 & 340 & $\mathrm{U}$ & 340 \\
\hline 4-Nitroaniline & 850 & $\mathrm{U}$ & 850 & 870 & $\mathrm{U}$ & 870 & 860 & 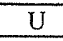 & 860 & 860 & $\mathrm{U}$ & 860 \\
\hline 4-Nitrophenol & 850 & $\mathrm{U}$ & 850 & 870 & $\mathrm{U}$ & 870 & 860 & $\mathrm{U}$ & 860 & 860 & $\mathrm{U}$ & 860 \\
\hline Acenaphthene & 340 & $\mathrm{U}$ & 340 & 350 & $\mathrm{U}$ & 350 & 350 & $\mathrm{U}$ & 350 & 340 & $\mathrm{U}$ & 340 \\
\hline Acenaphthylene & 340 & $\mathrm{U}$ & 340 & 350 & $\mathrm{U}$ & 350 & 350 & $\mathrm{U}$ & 350 & 340 & $\mathrm{U}$ & 340 \\
\hline Anthracene & 340 & $\mathrm{U}$ & 340 & 350 & $\mathrm{U}$ & 350 & 350 & $\mathrm{U}$ & 350 & 340 & $\mathrm{U}$ & 340 \\
\hline Benzo(a)anthracene & 340 & $\mathrm{U}$ & 340 & 21 & $\mathrm{~J}$ & 350 & 350 & $\mathrm{U}$ & 350 & 340 & $\mathrm{U}$ & 340 \\
\hline Benzo(a)pyrene & 340 & $\mathrm{U}$ & 340 & 20 & $\mathrm{~J}$ & 350 & 350 & $\bar{U}$ & 350 & 340 & $\mathrm{U}$ & 340 \\
\hline Benzo(b)fluoranthene & 340 & $\mathrm{U}$ & 340 & 18 & $\mathrm{~J}$ & 350 & 350 & $\mathrm{U}$ & 350 & 340 & $\mathrm{U}$ & 340 \\
\hline Benzo $(g, h, i)$ perylene & 340 & $\mathrm{U}$ & 340 & 350 & $\mathrm{U}$ & 350 & 350 & $\mathrm{U}$ & 350 & 340 & $\mathrm{U}$ & 340 \\
\hline Benzo(k)fluoranthene & 340 & $\mathrm{U}$ & 340 & 21 & $\mathrm{~J}$ & 350 & 350 & $\mathrm{U}$ & 350 & 340 & $\mathrm{U}$ & 340 \\
\hline bis(2-Chloro-1-methylethyl)ether & 340 & $\mathrm{U}$ & 340 & 350 & $\mathrm{U}$ & 350 & 350 & $\mathrm{U}$ & 350 & 340 & $\mathrm{U}$ & 340 \\
\hline bis(2-Chloroethoxy)methane & 340 & $\mathrm{U}$ & 340 & 350 & $\mathrm{U}$ & 350 & 350 & $\mathrm{U}$ & 350 & 340 & U & 340 \\
\hline bis(2-Chloroethyl) ether & 340 & $\mathrm{U}$ & 340 & 350 & $\mathrm{U}$ & 350 & 350 & $\mathrm{U}$ & 350 & 340 & $\mathrm{U}$ & 340 \\
\hline bis(2-Ethylhexyl) phthalate & 660 & $\mathrm{U}$ & 660 & 660 & $\mathrm{U}$ & 660 & 660 & $\mathrm{U}$ & 660 & 660 & $\mathrm{U}$ & 660 \\
\hline
\end{tabular}

\begin{tabular}{|c|c|c|c|}
\hline Attachment & 1 & Sheet No. & 6 of 9 \\
\hline Originator & M. J. Appel & Date & $05 / 30 / 06$ \\
\hline Checked & T. M. Blakley & Date & \\
\hline Calc. No. & $0100 \mathrm{~F}-\mathrm{CA}-\mathrm{V} 0251$ & Rev. No. & 0 \\
\hline
\end{tabular}


Attachment 1. 100-F-31 Verification Sampling Results.

\begin{tabular}{|c|c|c|c|c|c|c|c|c|c|c|c|c|}
\hline \multirow[t]{2}{*}{ Constituent } & \multicolumn{3}{|c|}{$\begin{array}{c}\text { J112D6 } \\
\text { Sample Location } 4 \\
\text { Sample Date } 2 / 6 / 06\end{array}$} & \multicolumn{3}{|c|}{$\begin{array}{c}\text { J112D7 } \\
\text { Sample Location } 5 \\
\text { Sample Date } 2 / 6 / 06 \\
\end{array}$} & \multicolumn{3}{|c|}{$\begin{array}{c}\text { J112D8 } \\
\text { Sample Location } 6 \\
\text { Sample Date 2/6/06 } \\
\end{array}$} & \multicolumn{3}{|c|}{$\begin{array}{c}\text { J112D9 } \\
\text { Sample Location } 7 \\
\text { Sample Date } 2 / 6 / 06\end{array}$} \\
\hline & $\mu \mathrm{g} / \mathrm{kg}$ & $Q$ & PQL & $\mu \mathrm{g} / \mathrm{kg}$ & $Q$ & PQL & $\mu \mathrm{g} / \mathrm{kg}$ & Q & PQL & $\mu \mathrm{g} / \mathrm{kg}$ & Q & $\mathrm{PQL}$ \\
\hline \multicolumn{13}{|c|}{ Semivolatile Organic Compounds (continued) } \\
\hline Butylbenzylphthalate & 340 & $\mathrm{U}$ & 340 & 350 & $\mathrm{U}$ & 350 & 350 & $\mathrm{U}$ & 350 & 340 & $\mathrm{U}$ & 340 \\
\hline Carbazole & 340 & $\mathrm{U}$ & 340 & 350 & $\mathrm{U}$ & 350 & 350 & $\mathrm{U}$ & 350 & 340 & $\mathrm{U}$ & 340 \\
\hline Chrysene & 340 & $\mathrm{U}$ & 340 & 30 & $\mathrm{~J}$ & 350 & 350 & $\mathrm{U}$ & 350 & 340 & $\mathrm{U}$ & 340 \\
\hline Dibenz(a,h)anthracene & 340 & $U$ & 340 & 350 & $\mathrm{U}$ & 350 & 350 & $\mathrm{U}$ & 350 & 340 & $\mathrm{U}$ & 340 \\
\hline Dibenzofuran & 340 & $\mathrm{U}$ & 340 & 350 & $\mathrm{U}$ & 350 & 350 & $\mathrm{U}$ & 350 & 340 & $\mathrm{U}$ & 340 \\
\hline Diethylphthalate & 340 & $\mathrm{U}$ & 340 & 350 & $\mathrm{U}$ & 350 & 350 & $\mathrm{U}$ & 350 & 340 & $\mathrm{U}$ & 340 \\
\hline Dimethylphthalate & 340 & $\mathrm{U}$ & 340 & 350 & $\mathrm{U}$ & 350 & 350 & $\mathrm{U}$ & 350 & 340 & $\mathrm{U}$ & 340 \\
\hline Di-n-butylphthalate & 340 & $\mathrm{U}$ & 340 & 660 & $\mathrm{U}$ & 660 & 350 & $\mathrm{U}$ & 350 & 660 & $\mathrm{U}$ & 660 \\
\hline Di-n-octylphthalate & 340 & $\mathrm{U}$ & 340 & 350 & $\mathrm{U}$ & 350 & 350 & $\mathrm{U}$ & 350 & 340 & $\mathrm{U}$ & 340 \\
\hline Fluoranthene & 340 & $\mathrm{U}$ & 340 & 34 & $\mathrm{~J}$ & 350 & 350 & $\mathrm{U}$ & 350 & 340 & $\mathrm{U}$ & 340 \\
\hline \begin{tabular}{|l|} 
Fluorene \\
\end{tabular} & 340 & $\mathrm{U}$ & 340 & 350 & $\mathrm{U}$ & 350 & 350 & $\mathrm{U}$ & 350 & 340 & $\mathrm{U}$ & 340 \\
\hline Hexachlorobenzene & 340 & $\mathrm{U}$ & 340 & 350 & $\mathrm{U}$ & 350 & 350 & $\mathrm{U}$ & 350 & 340 & $\mathrm{U}$ & 340 \\
\hline Hexachlorobutadiene & 340 & $\mathrm{U}$ & 340 & 350 & $\mathrm{U}$ & 350 & 350 & $\mathrm{U}$ & 350 & 340 & $\mathrm{U}$ & 340 \\
\hline Hexachlorocyclopentadiene & 340 & $\mathrm{U}$ & 340 & 350 & $\mathrm{U}$ & 350 & 350 & $\mathrm{U}$ & 350 & 340 & $\mathrm{U}$ & 340 \\
\hline Hexachloroethane & 340 & $\mathrm{U}$ & 340 & 350 & $\mathrm{U}$ & 350 & 350 & $\mathrm{U}$ & 350 & 340 & $\mathrm{U}$ & 340 \\
\hline Indeno $(1,2,3$-cd)pyrene & 340 & $\mathrm{U}$ & 340 & 350 & $\mathrm{U}$ & 350 & 350 & $\mathrm{U}$ & 350 & 340 & $\mathrm{U}$ & 340 \\
\hline Isophorone & 340 & U & 340 & 350 & $U$ & 350 & 350 & $\mathrm{U}$ & 350 & 340 & $\mathrm{U}$ & 340 \\
\hline Naphthalene & 340 & $\mathrm{U}$ & 340 & 350 & $\mathrm{U}$ & 350 & 350 & $\mathrm{U}$ & 350 & 340 & $\mathrm{U}$ & 340 \\
\hline Nitrobenzene & 340 & $\mathrm{U}$ & 340 & 350 & $\mathrm{U}$ & 350 & 350 & $\mathrm{U}$ & 350 & 340 & $\mathrm{U}$ & 340 \\
\hline $\mathrm{N}$-Nitroso-di-n-dipropylamine & 340 & $\mathrm{U}$ & 340 & 350 & U & 350 & 350 & $\mathrm{U}$ & 350 & 340 & $\mathrm{U}$ & 340 \\
\hline N-Nitrosodiphenylamine & 340 & $\mathrm{U}$ & 340 & 350 & $\mathrm{U}$ & 350 & 350 & $\mathrm{U}$ & 350 & 340 & $\mathrm{U}$ & 340 \\
\hline Pentachlorophenol & 850 & $\mathrm{U}$ & 850 & 870 & $U$ & 870 & 860 & $\mathrm{U}$ & 860 & 860 & $\mathrm{U}$ & 860 \\
\hline Phenanthrene & 340 & $\mathrm{U}$ & 340 & 350 & $\mathrm{U}$ & 350 & 350 & $\mathrm{U}$ & 350 & 340 & $\mathrm{U}$ & 340 \\
\hline Phenol & 340 & $\mathrm{U}$ & 340 & 350 & $\mathrm{U}$ & 350 & 350 & $\mathrm{U}$ & 350 & 340 & $\mathrm{U}$ & 340 \\
\hline Pyrene & 340 & $U$ & 340 & 44 & $\mathrm{~J}$ & 350 & 350 & $\mathrm{U}$ & 350 & 340 & $U$ & 340 \\
\hline
\end{tabular}

Attachment

Originator

Checked

Calc. No.

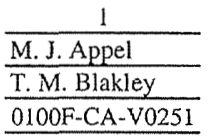

Sheet No. $\frac{7 \text { of } 9}{\text { Date }}$
Date
Rev. No. 
Attachment 1. 100-F-31 Verification Sampling Results.

\begin{tabular}{|c|c|c|c|c|c|c|c|c|c|c|c|c|}
\hline \multirow[t]{2}{*}{ Constituent } & \multicolumn{3}{|c|}{\begin{tabular}{|c|} 
J112F0 \\
Sample Location 8 \\
Sample Date 2/6/06 \\
\end{tabular}} & \multicolumn{3}{|c|}{$\begin{array}{c}\text { J112F1 } \\
\text { Sample Location } 9 \\
\text { Sample Date } 2 / 6 / 06 \\
\end{array}$} & \multicolumn{3}{|c|}{$\begin{array}{c}\text { J112F2 } \\
\text { Sample Location } 10 \\
\text { Sample Date } 2 / 6 / 06\end{array}$} & \multicolumn{3}{|c|}{$\begin{array}{c}\text { J112F4 } \\
\text { Equipment Blank } \\
\text { Sample Date } 2 / 6 / 06\end{array}$} \\
\hline & $\mu \mathrm{g} / \mathrm{kg}$ & $Q$ & PQL & $\mu \mathrm{g} / \mathrm{kg}$ & $\mathrm{Q}$ & $\mathrm{PQL}$ & $\mu \mathrm{g} / \mathrm{kg}$ & $Q$ & $\mathrm{PQL}$ & $\mu \mathrm{g} / \mathrm{kg}$ & $Q$ & $\mathrm{PQL}$ \\
\hline \multicolumn{13}{|c|}{ Polychlorinated Biphenyls } \\
\hline Aroclor-1016 & 14 & $\mathrm{U}$ & 14 & 14 & $\mathrm{U}$ & 14 & 700 & UDJ & 700 & & & \\
\hline Aroclor- 1221 & 14 & $\mathrm{U}$ & 14 & 14 & $\bar{U}$ & 14 & 700 & UDJ & 700 & & & \\
\hline Aroclor-1232 & 14 & $\mathrm{U}$ & 14 & 14 & $\mathrm{U}$ & 14 & 700 & UDJ & 700 & & & \\
\hline Aroclor -1242 & 14 & $\mathrm{U}$ & 14 & 14 & U & 14 & 700 & UDJ & 700 & & & \\
\hline Aroclor- 1248 & 14 & $\mathrm{U}$ & 14 & 14 & $\mathrm{U}$ & 14 & 7300 & UDJ & 700 & & & \\
\hline Aroclor-1254 & 31 & $\mathrm{~J}$ & 14 & 20 & $\mathrm{~J}$ & 14 & 700 & UDJ & 700 & & & \\
\hline Aroclor- 1260 & 14 & $\mathrm{U}$ & 14 & 14 & $\mathrm{U}$ & 14 & 700 & UDJ & 700 & & & \\
\hline \multicolumn{13}{|c|}{ Semivolatile Organic Compounds } \\
\hline 1,2,4-Trichlorobenzene & 340 & UJ & 340 & 350 & $\mathrm{UJ}$ & 350 & 350 & UJ & 350 & 330 & UJ & 330 \\
\hline 1,2-Dichlorobenzene & 340 & $\mathrm{U}$ & 340 & 350 & $\mathrm{U}$ & 350 & 350 & $\mathrm{U}$ & 350 & 330 & $\mathrm{U}$ & 330 \\
\hline 1,3-Dichlorobenzene & 340 & $\mathrm{U}$ & 340 & 350 & $\mathrm{U}$ & 350 & 350 & $\mathrm{U}$ & 350 & 330 & $\mathrm{U}$ & 330 \\
\hline 1,4-Dichlorobenzene & 340 & $\mathrm{U}$ & 340 & 350 & $\mathrm{U}$ & 350 & 350 & $\mathrm{U}$ & 350 & 330 & $\bar{U}$ & 330 \\
\hline 2,4,5-Trichlorophenol & 860 & $\mathrm{U}$ & 860 & 880 & $\mathrm{U}$ & 880 & 880 & $\mathrm{U}$ & 880 & 830 & $\mathrm{U}$ & 830 \\
\hline 2,4,6-Trichlorophenol & 340 & $\mathrm{U}$ & 340 & 350 & $\mathrm{U}$ & 350 & 350 & $\mathrm{U}$ & 350 & 330 & $\mathrm{U}$ & 330 \\
\hline 2,4-Dichlorophenol & 340 & $\mathrm{U}$ & 340 & 350 & $\mathrm{U}$ & 350 & 350 & $\mathrm{U}$ & 350 & 330 & $\mathrm{U}$ & 330 \\
\hline 2,4-Dimethylphenol & 340 & UJ & 340 & 350 & UJ & 350 & 350 & UJ & 350 & 330 & $\mathrm{UJ}$ & 330 \\
\hline 2,4-Dinitrophenol & 860 & $\mathrm{U}$ & 860 & 880 & $\mathrm{U}$ & 880 & 880 & $\mathrm{U}$ & 880 & 830 & $\mathrm{U}$ & 830 \\
\hline 2,4-Dinitrotoluene & 340 & $\mathrm{U}$ & 340 & 350 & $U$ & 350 & 350 & $\mathrm{U}$ & 350 & 330 & $\mathrm{U}$ & 330 \\
\hline 2,6-Dinitrotoluene & 340 & $\mathrm{U}$ & 340 & 350 & $\mathrm{U}$ & 350 & 350 & $U$ & 350 & 330 & $\mathrm{U}$ & 330 \\
\hline 2-Chloronaphthalene & 340 & $\mathrm{U}$ & 340 & 350 & U & 350 & 350 & $\mathrm{U}$ & 350 & 330 & $\mathrm{U}$ & 330 \\
\hline 2-Chlorophenol & 340 & $\mathrm{U}$ & 340 & 350 & $\mathrm{U}$ & 350 & 350 & U & 350 & 330 & $\mathrm{U}$ & 330 \\
\hline 2-Methylnaphthalene & 340 & $\mathrm{U}$ & 340 & 350 & $\mathrm{U}$ & 350 & 350 & $\mathrm{U}$ & 350 & 330 & $\mathrm{U}$ & 330 \\
\hline 2-Methylphenol (cresol, o-) & 340 & $\mathrm{U}$ & 340 & 350 & $\mathrm{U}$ & 350 & 350 & $\mathrm{U}$ & 350 & 330 & $\mathrm{U}$ & 330 \\
\hline 2-Nitroaniline & 860 & $\mathrm{U}$ & 860 & 880 & $\mathrm{U}$ & 880 & 880 & $\mathrm{U}$ & 880 & 830 & $\mathrm{U}$ & 830 \\
\hline 2-Nitrophenol & 340 & $\mathrm{U}$ & 340 & 350 & $\mathrm{U}$ & 350 & 350 & $\mathrm{U}$ & 350 & 330 & $\mathrm{U}$ & 330 \\
\hline 3,3'-Dichlorobenzidine & 340 & $\mathrm{U}$ & 340 & 350 & $\mathrm{U}$ & 350 & 350 & $\mathrm{U}$ & 350 & 330 & $\mathrm{U}$ & 330 \\
\hline 4-Methylphenol (p-cresol) & 340 & $\mathrm{U}$ & 340 & 350 & $\mathrm{U}$ & 350 & 350 & $\bar{U}$ & 350 & 330 & $\mathrm{U}$ & 330 \\
\hline 3-Nitroaniline & 860 & $\mathrm{U}$ & 860 & 880 & $\mathrm{U}$ & 880 & 880 & $\mathrm{U}$ & 880 & 830 & $\mathrm{U}$ & 830 \\
\hline 4,6-Dinitro-2-methylphenol & 860 & $\mathrm{U}$ & 860 & 880 & $\mathrm{U}$ & 880 & 880 & $\mathrm{U}$ & 880 & 830 & $\mathrm{U}$ & 830 \\
\hline 4-Bromophenyl-phenylether & 340 & $\mathrm{U}$ & 340 & 350 & $\mathrm{U}$ & 350 & 350 & U & 350 & 330 & $\mathrm{U}$ & 330 \\
\hline 4-Chloro-3-methylphenol & 340 & $\mathrm{U}$ & 340 & 350 & $\mathrm{U}$ & 350 & 350 & $\mathrm{U}$ & 350 & 330 & $\mathrm{U}$ & 330 \\
\hline 4-Chloroaniline & 340 & $\mathrm{U}$ & 340 & 350 & $\mathrm{U}$ & 350 & 350 & $\mathrm{U}$ & 350 & 330 & $\mathrm{U}$ & 330 \\
\hline 4-Chlorophenyl-phenylether & 340 & $\mathrm{U}$ & 340 & 350 & $\mathrm{U}$ & 350 & 350 & $\mathrm{U}$ & 350 & 330 & $\mathrm{U}$ & 330 \\
\hline 4-Nitroaniline & 860 & $\mathrm{U}$ & 860 & 880 & $\mathrm{U}$ & 880 & 880 & $\mathrm{U}$ & 880 & 830 & $\mathrm{U}$ & 830 \\
\hline 4-Nitrophenol & 860 & $\mathrm{U}$ & 860 & 880 & $\mathrm{U}$ & 880 & 880 & $\mathrm{U}$ & 880 & 830 & $\mathrm{U}$ & 830 \\
\hline Acenaphthene & 340 & $\mathrm{U}$ & 340 & 350 & $\mathrm{U}$ & 350 & 350 & $\mathrm{U}$ & 350 & 330 & $\mathrm{U}$ & 330 \\
\hline Acenaphthylene & 340 & $\mathrm{U}$ & 340 & 350 & $\mathrm{U}$ & 350 & 350 & $\mathrm{U}$ & 350 & 330 & $\mathrm{U}$ & 330 \\
\hline Anthracene & 340 & $\mathrm{U}$ & 340 & 350 & $\mathrm{U}$ & 350 & 350 & $\mathrm{U}$ & 350 & 330 & $\mathrm{U}$ & 330 \\
\hline Benzo(a)anthracene & 52 & $\mathrm{~J}$ & 340 & 21 & $\mathrm{~J}$ & 350 & 54 & $\mathrm{~J}$ & 350 & 330 & $\mathrm{U}$ & 330 \\
\hline Benzo(a)pyrene & 43 & $\mathrm{~J}$ & 340 & 350 & $\mathrm{U}$ & 350 & 46 & $\mathrm{~J}$ & 350 & 330 & $\mathrm{U}$ & 330 \\
\hline Benzo(b)fluoranthene & 35 & $\mathrm{~J}$ & 340 & 350 & $\mathrm{U}$ & 350 & 42 & $J$ & 350 & 330 & $\mathrm{U}$ & 330 \\
\hline Benzo(g,h,i)perylene & 23 & $\mathrm{~J}$ & 340 & 350 & $\mathrm{U}$ & 350 & 28 & $\mathrm{~J}$ & 350 & 330 & $\mathrm{U}$ & 330 \\
\hline Benzo(k)fluoranthene & 42 & $\mathrm{~J}$ & 340 & 19 & $\mathrm{~J}$ & 350 & 48 & $\mathrm{~J}$ & 350 & 330 & $\mathrm{U}$ & 330 \\
\hline bis(2-Chloro-1-methylethyl)ether & 340 & $\mathrm{U}$ & 340 & 350 & $\mathrm{U}$ & 350 & 350 & $\mathrm{U}$ & 350 & 330 & $\mathrm{U}$ & 330 \\
\hline bis(2-Chloroethoxy)methane & 340 & $\mathrm{U}$ & 340 & 350 & $\mathrm{U}$ & 350 & 350 & $\mathrm{U}$ & 350 & 330 & $\mathrm{U}$ & 330 \\
\hline bis(2-Chloroethyl) ether & 340 & $\mathrm{U}$ & 340 & 350 & $\mathrm{U}$ & 350 & 350 & $\mathrm{U}$ & 350 & 330 & $\mathrm{U}$ & 330 \\
\hline bis(2-Ethylhexyl) phthalate & 660 & $\mathrm{U}$ & 660 & 660 & $\mathrm{U}$ & 660 & 660 & $\mathrm{U}$ & 660 & 660 & $\mathrm{U}$ & 660 \\
\hline
\end{tabular}

Attachment Originator

Checked

Calc. No.

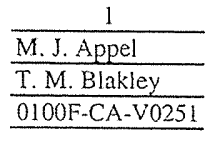

Shect No. $\frac{8 \text { of } 9}{05 / 30 / 06}$
Date
Date
Rev. No. 0 
Attachment 1. 100-F-31 Verification Sampling Results.

\begin{tabular}{|c|c|c|c|c|c|c|c|c|c|c|c|c|}
\hline \multirow[t]{2}{*}{ Constituent } & \multicolumn{3}{|c|}{$\begin{array}{c}\text { J112F0 } \\
\text { Sample Location } 8 \\
\text { Sample Date } 2 / 6 / 06 \\
\end{array}$} & \multicolumn{3}{|c|}{$\begin{array}{c}\text { J112F1 } \\
\text { Sample Location } 9 \\
\text { Sample Date } 2 / 6 / 06 \\
\end{array}$} & \multicolumn{3}{|c|}{$\begin{array}{c}\text { J112F2 } \\
\text { Sample Location } 10 \\
\text { Sample Date } 2 / 6 / 06 \\
\end{array}$} & \multicolumn{3}{|c|}{$\begin{array}{c}\text { J112F4 } \\
\text { Equipment Blank } \\
\text { Sample Date } 2 / 6 / 06 \\
\end{array}$} \\
\hline & $\mu \mathrm{g} / \mathrm{kg}$ & $Q$ & PQL & $\mu \mathrm{g} / \mathrm{kg}$ & $\mathrm{Q}$ & PQL & $\mu \mathrm{g} / \mathrm{kg}$ & $Q$ & PQL & $\mu \mathrm{g} / \mathrm{kg}$ & Q & $\mathrm{PQL}$ \\
\hline \multicolumn{13}{|c|}{ Semivolatile Organic Compounds (continued) } \\
\hline Butylbenzylphthalate & 340 & $\mathrm{U}$ & 340 & 350 & $\mathrm{U}$ & 350 & 350 & $\mathrm{U}$ & 350 & 330 & $\mathrm{U}$ & 330 \\
\hline Carbazole & 340 & $\mathrm{U}$ & 340 & 350 & $\mathrm{U}$ & 350 & 350 & $\mathrm{U}$ & 350 & 330 & $\mathrm{U}$ & 330 \\
\hline Chrysene & 63 & $\mathrm{~J}$ & 340 & 28 & $\mathrm{~J}$ & 350 & 65 & $\mathrm{~J}$ & 350 & 330 & $\mathrm{U}$ & 330 \\
\hline Dibenz $(a, h)$ anthracene & 340 & $\mathrm{U}$ & 340 & 350 & U & 350 & 350 & $\mathrm{U}$ & 350 & 330 & $\mathrm{U}$ & 330 \\
\hline Dibenzofuran & 340 & $\mathrm{U}$ & 340 & 350 & $\mathrm{U}$ & 350 & 350 & $\mathrm{U}$ & 350 & 330 & $\mathrm{U}$ & 330 \\
\hline Diethylphthalate & 340 & $\mathrm{U}$ & 340 & 350 & $\mathrm{U}$ & 350 & 350 & $\mathrm{U}$ & 350 & 330 & $\mathrm{U}$ & 330 \\
\hline Dimethylphthalate & 340 & $\mathrm{U}$ & 340 & 350 & $\mathrm{U}$ & 350 & 350 & $\mathrm{U}$ & 350 & 330 & $\mathrm{U}$ & 330 \\
\hline Di-n-butylphthalate & 660 & U & 660 & 660 & $\mathrm{U}$ & 660 & 660 & $\mathrm{U}$ & 660 & 660 & $\mathrm{U}$ & 660 \\
\hline Di-n-octylphthalate & 340 & $\mathrm{U}$ & 340 & 350 & $U$ & 350 & 350 & $\mathrm{U}$ & 350 & 330 & U & 330 \\
\hline Fluoranthene & 88 & $\mathrm{~J}$ & 350 & 37 & $\mathrm{~J}$ & 350 & 83 & $\mathrm{~J}$ & 350 & 330 & $\mathrm{U}$ & 330 \\
\hline Fluorene & 340 & $\mathrm{U}$ & 340 & 350 & $\mathrm{U}$ & 350 & 350 & $\mathrm{U}$ & 350 & 330 & $\mathrm{U}$ & 330 \\
\hline Hexachlorobenzene & 340 & $\mathrm{U}$ & 340 & 350 & U & 350 & 350 & $\mathrm{U}$ & 350 & 330 & $\mathrm{U}$ & 330 \\
\hline Hexachlorobutadiene & 340 & $\mathrm{U}$ & 340 & 350 & $\mathrm{U}$ & 350 & 350 & $\mathrm{U}$ & 350 & 330 & $\mathrm{U}$ & 330 \\
\hline Hexachlorocyclopentadiene & 340 & $\mathrm{U}$ & 340 & 350 & $\mathrm{U}$ & 350 & 350 & $\mathrm{U}$ & 350 & 330 & $\mathrm{U}$ & 330 \\
\hline Hexachloroethane & 340 & $\mathrm{U}$ & 340 & 350 & $\mathrm{U}$ & 350 & 350 & $\mathrm{U}$ & 350 & 330 & $\mathrm{U}$ & 330 \\
\hline Indeno $(1,2,3-\mathrm{cd})$ pyrene & 22 & $\mathrm{~J}$ & 340 & 350 & $\mathrm{U}$ & 350 & 25 & $\mathrm{~J}$ & 350 & 330 & $\mathrm{U}$ & 330 \\
\hline Isophorone & 340 & $\mathrm{U}$ & 340 & 350 & U & 350 & 350 & $\mathrm{U}$ & 350 & 330 & $\mathrm{U}$ & 330 \\
\hline Naphthalene & 340 & $\mathrm{U}$ & 340 & 350 & $\mathrm{U}$ & 350 & 350 & $\mathrm{U}$ & 350 & 330 & $\mathrm{U}$ & 3.30 \\
\hline Nitrobenzene & 340 & U & 340 & 350 & $\mathrm{U}$ & 350 & 350 & $\mathrm{U}$ & 350 & 330 & $\mathrm{U}$ & 330 \\
\hline N-Nitroso-di-n-dipropylamine & 340 & $\mathrm{U}$ & 340 & 350 & $\mathrm{U}$ & 350 & 350 & $\mathrm{U}$ & 350 & 330 & $\mathrm{U}$ & 330 \\
\hline N-Nitrosodiphenylamine & 340 & U & 340 & 350 & $\mathrm{U}$ & 350 & 350 & $\mathrm{U}$ & 350 & 330 & $\mathrm{U}$ & 330 \\
\hline Pentachlorophenol & 860 & $\mathrm{U}$ & 860 & 880 & $\mathrm{U}$ & 880 & 880 & $\mathrm{U}$ & 880 & 830 & $\mathrm{U}$ & 830 \\
\hline Phenanthrene & 34 & $\mathrm{~J}$ & 340 & 350 & $\mathrm{U}$ & 350 & 30 & $J$ & 350 & 330 & $\mathrm{U}$ & 330 \\
\hline Phenol & 340 & $\mathrm{U}$ & 340 & 350 & U & 350 & 350 & $U$ & 350 & 330 & $\mathrm{U}$ & 330 \\
\hline Pyrene & 120 & $\mathrm{~J}$ & 340 & 42 & $\mathrm{~J}$ & 350 & 110 & $J$ & 350 & 330 & $\mathrm{U}$ & 330 \\
\hline
\end{tabular}

\begin{tabular}{|c|c|c|c|}
\hline Attachment & 1 & Sheet No. & 9 of 9 \\
\hline Originator & M. J. Appel & Date & $05 / 30 / 06$ \\
\hline Checked & T. M. Blakley & Date & \\
\hline Calc. No. & $0100 \mathrm{~F}-\mathrm{CA}-\mathrm{V} 0251$ & Rev. No. & 0 \\
\hline
\end{tabular}




\section{CALCULATION COVER SHEET}

Project Title:

Area

Discipline

Subject

Computer Program
100-F Area Field Remediation

Job No.

$100-F$

Environmental

100-F-31 Phase II Cleanup Ve

Excel

*Calc. No. 0100F-CA-V0252

14655

The attached calculations have been generated to document compliance with established cleanup levels. These calculations should be used in conjunction with other relevant documents in the administrative record.

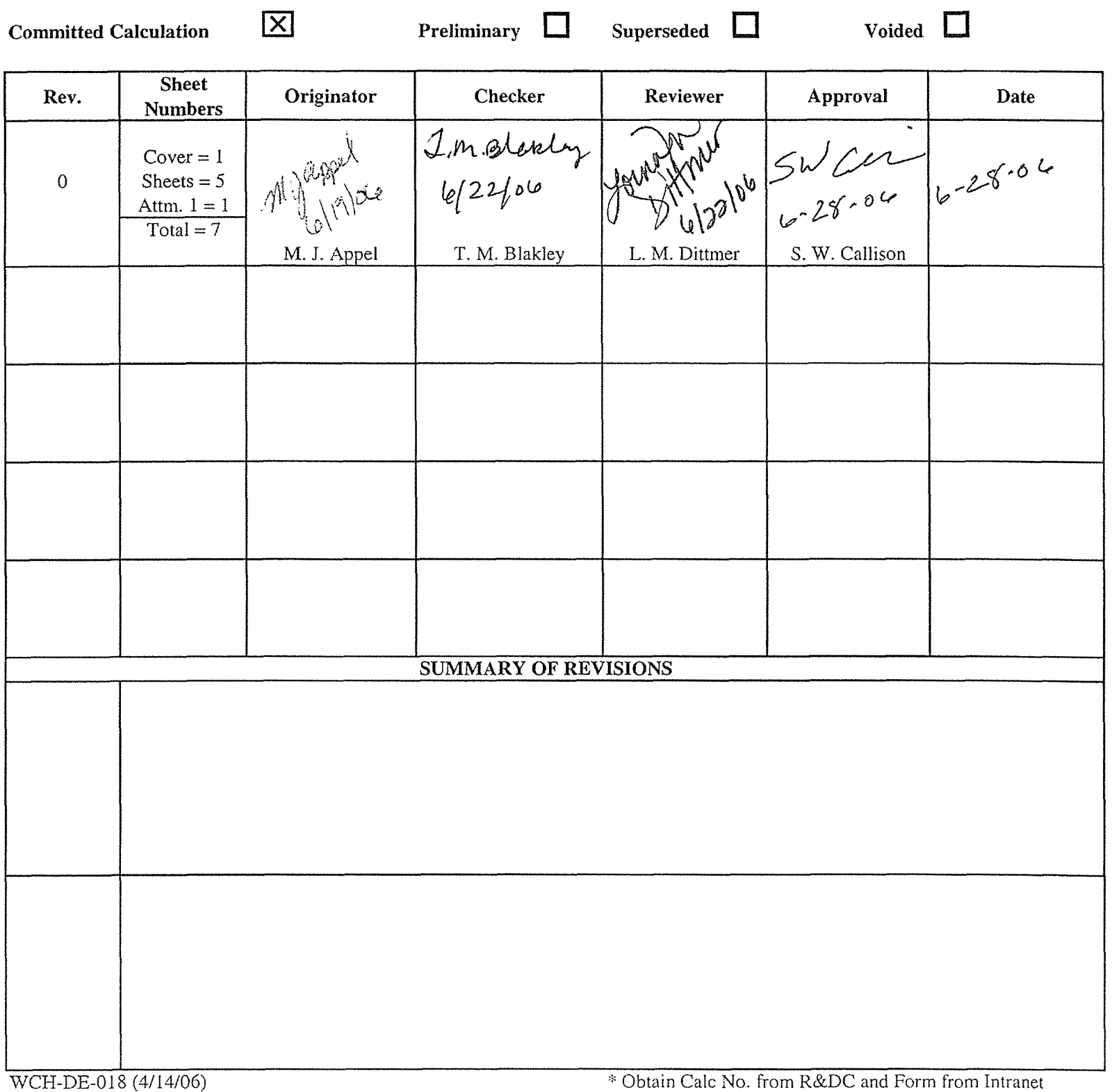


Washington Closure Hanford

Originator M. J. Appel III/f
Project
Subject
100-F Area Field Remediation

Calc. No, 0100F-CA-V0252 Checked T.M. Blakley $\operatorname{ImP}$
Rev. No. 0 Date $\overline{6 / 22 / 06}$ Sheet No. Ti of 5

Summary

1 Purpose:

2 Calculate the $95 \%$ upper confidence limit (UCL) values to evaluate compliance with cleanup standards for the remediation footprint of the subject site. Also, perform the Washington Administrative Code (WAC) 173-340-740(7)(e) 3-part test for nonradionuclide analytes and calculate the relative percent difference (RPD) for primary-duplicate sample pairs, as necessary. This calculation evaluates the 100-F-31 Phase II sampling for polychlorinated biphenyls (PCBs). The Phase I calculation is provided in 0100F-CA-V0251.

Table of Contents:

Sheets 1 to 3 - Calculation Sheet Summary

Sheet 4 - Calculation Sheet - Verification Data and Duplicate Analysis

Sheet 5 - Ecology Software (MTCAStat) Results

Attachment 1 - 100-F-31 Verification Sampling Results (1 sheet)

\section{Given/References:}

1) Sample Results (Attachment 1).

2) Background values and remedial action goals (RAGs) are taken from DOE-RL (2005b), DOE-RL (2001), and Ecology (2005).

3) DOE-RL, 2001, Hanford Site Background: Part 1, Soil Background for Nonradioactive Analytes, DOE/RL-92-24, Rev. 4, U.S. Department of Energy, Richland Operations Office, Richland, Washington.

4) DOE-RL, 2005a, 100 Area Remedial Action Sampling and Analysis Plan (SAP), DOE/RL-96-22, Rev. 4, U.S. Department of Energy, Richland Operations Office, Richland, Washington.

5) DOE-RL, 2005b, Remedial Design Report/Remedial Action Work Plan for the 100 Area (RDR/RAWP), DOE/RL-96-17, Rev. 5, U.S. Department of Energy, Richland Operations Office, Richland, Washington.

6) Ecology, 1992, Statistical Guidance for Ecology Site Managers, Publication \$92-54, Washington Department of Ecology, Olympia, Washington.

7) Ecology, 1993, Statistical Guidance for Ecology Site Managers, Supplement S-6, Analyzing Site or Background Data with Below-detection Limit or Below-PQL Values (Censored Data Sets), Publication \#92-54, Washington Department of Ecology, Olympia, Washington.

8) Ecology, 2005, Cleantu Levels and Risk Calculations (CLARC) Database, Washington State Department of Ecology, Olympia, Washington, <https://fortress.wa.gov/ecy/clarc/CLARCHome.aspx>.

9) EPA, 1994, USEPA Contract Laboratory Program National Functional Guidelines for Inorganic Data Review, EPA 540/R-94/013, U.S. Environmental Protection Agency, Washington, D.C.

10) WAC 173-340, 1996, "Model Toxic Control Act - Cleanup," Washington Administrative Code.

Solution:

Calculation methodology is described in Ecology Pub. \#92-54 (Ecology 1992, 1993), below, and in the RDR/RAWP (DOE-RL 2005b). Use data from attached worksheets to perform the 95\% UCL calculation for each analyte, the WAC 173-340-740(7)(e) 3-part test for nonradionuclides, and the RPD calculations for each COC/COPC, as required. The hazard quotient and carcinogenic risk calculations are located in a separate calculation brief as an appendix to the Remaining Sites Verification Package (RSVP).

Calculation Description:

The subject calculations were performed on data from soil verification samples from the subject waste site. The data were entered into an EXCEL 2003 spreadsheet and calculations performed by using the built-in spreadsheet functions and/or creating formulae within the cells. The statistical evaluation of data for use in accordance with the RDR/RAWP (DOE-RL 2005b) is documented by this calculation. Duplicate RPD results are used in evaluation of data quality within the RSVP for this site. 


\section{CALCULATION SHEET}

Washington Closure Hanford

Originator M. J. Appel $\mathrm{N}^{\mathrm{i}} \mathrm{M}$
$\quad$ Project
Subject

Calc. No. 0100F-CA-V0252 Checked T. M. Blakley Jan

Rev. No. $\quad 0$

Date $\overline{6 / 22 / 26}$

Sheet No. 2015

Summary (continued)

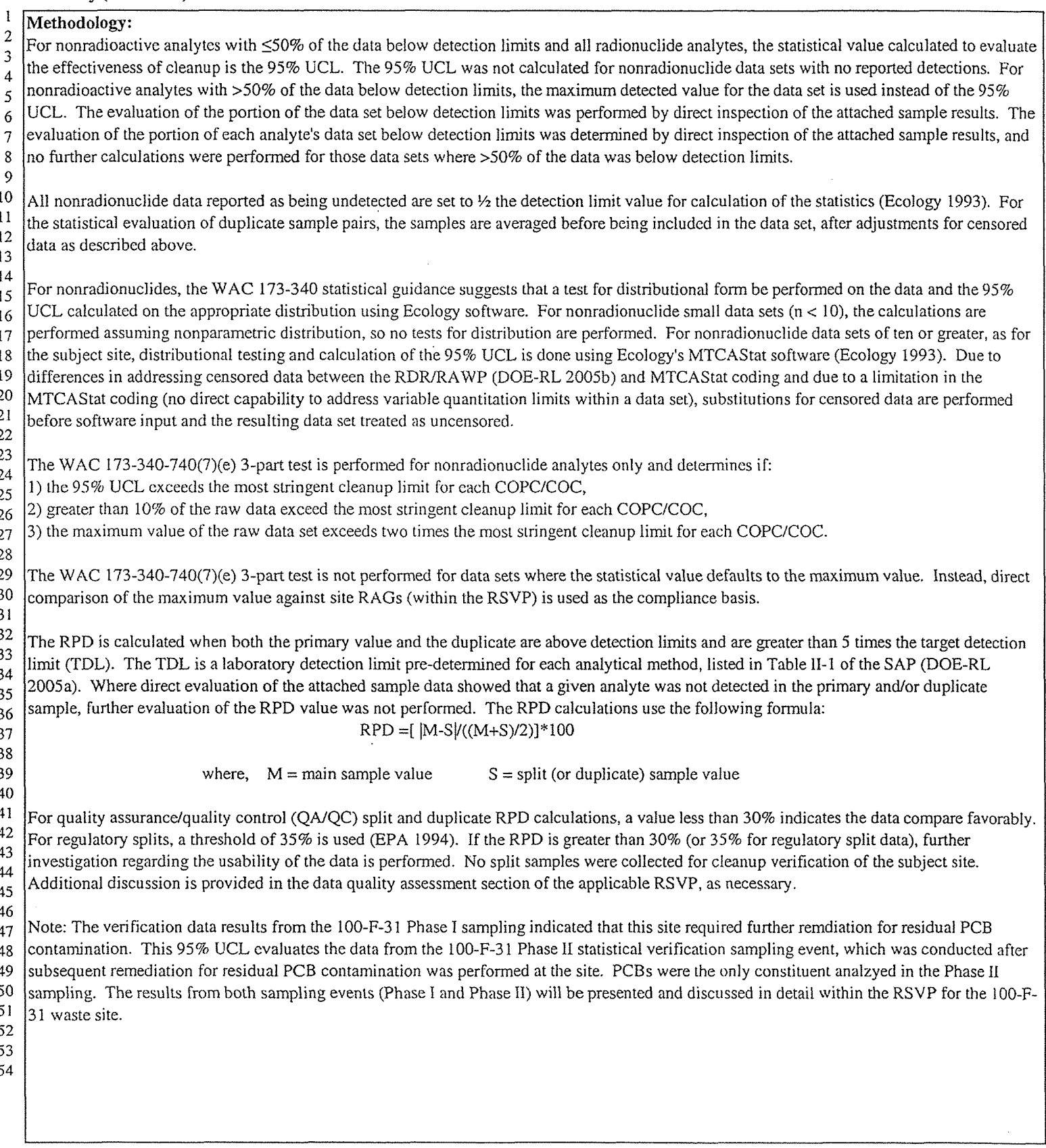




\section{Washington Closure Hanford}

\section{CALCULATION SHEET}

Originator M. J. Appel $M ! / f d$
Project

Subject 100-F-31 Phase II Cleanup Verification 95\% UCL Calculations
Calc. No. 0100F-CA-V0252 Checked T.M. Blakley Tag
Rev. No. $\quad 0$ Date $122 / 06$ Sheet No. 3 of 5

1 Summary (continued)

2 Results:

3 The results presented in the summary tables that follow are for use in risk analysis and the RSVP for this site.

4

$6 \longdiv { \text { Results Summary - Remediation Footprint } }$

\begin{tabular}{|c|c|c|}
\hline Analyte & $95 \%$ UCL & Units \\
\hline
\end{tabular}

\begin{tabular}{|l|c|c|}
\hline 8 Aroclor-1254 & 0.016 & $\mathrm{mg} / \mathrm{kg}$
\end{tabular}

9

10

11 WAC 173-340-740(7)(e) Evaluation

12

13 WAC 173-340 3-Part Test for most stringent RAG:

$1495 \%$ UCL > Cleanup Limit? NO

$15>10 \%$ above Cleanup Limit? NO

16 Any sample $>2 x$ Cleanup Limit? NO

17

18 MTCA $=$ Model Toxic Control Act

$19 \mathrm{RAG}=$ remedial action goal

20 RESRAD $=$ RESidual RADioactivity (dose assessment model)

$21 \mathrm{UCL}=$ upper confidence level

$22 \mathrm{WAC}=$ Washington Adminstrative Code 
CALCULATION SHEET

\begin{tabular}{|c|c|c|c|c|c|c|c|c|c|c|c|}
\hline \multirow{3}{*}{\multicolumn{3}{|c|}{$\begin{array}{l}\text { Originator M. J. Appel } \\
\text { Project } \\
\text { Subject } \frac{100-\mathrm{F} \text { Area Field Rèthediation }}{100-\mathrm{F}-31 \text { Phase II Cleanup Ve }}\end{array}$}} & \multirow{2}{*}{\multicolumn{2}{|c|}{$\begin{array}{r}\text { Date } \\
\text { Job No. }\end{array}$}} & \multirow{2}{*}{$\frac{06 / 19 / 06}{14655}$} & \multirow{2}{*}{\multicolumn{2}{|c|}{$\begin{array}{l}\text { Calc. No. } \frac{0100 F-C A-V 0252}{} \\
\text { Checked T. M. Blakley }\end{array}$}} & & \multirow{2}{*}{\multicolumn{3}{|c|}{ Rev. No. $\frac{0}{\text { Date }}$}} \\
\hline & & & & & & & & & & & \\
\hline & & & ation 95 & UCL & alculations & & & & Sheet No. & t & of 5 \\
\hline \multicolumn{6}{|c|}{ Remediation Footprint Verification Data } & \multicolumn{6}{|c|}{ Duplicate Analysis } \\
\hline \multirow{2}{*}{\begin{tabular}{|l|} 
Sample \\
Location \\
\end{tabular}} & \multirow{2}{*}{$\begin{array}{c}\text { HEIS } \\
\text { Number }\end{array}$} & \multirow{2}{*}{$\begin{array}{c}\text { Sample } \\
\text { Date }\end{array}$} & \multicolumn{3}{|c|}{ Aroclor-1254 } & \multirow{2}{*}{$\begin{array}{c}\text { Sampling } \\
\text { Area }\end{array}$} & \multirow{2}{*}{$\begin{array}{c}\text { HEIS } \\
\text { Number }\end{array}$} & \multirow{2}{*}{$\begin{array}{c}\text { Sample } \\
\text { Date }\end{array}$} & \multicolumn{3}{|c|}{ Aroclor-1254 } \\
\hline & & & $\mathrm{mg} / \mathrm{kg}$ & $Q$ & $\mathrm{PQL}$ & & & & $\mathrm{mg} / \mathrm{kg}$ & Q & $\mathrm{PQL}$ \\
\hline 4 & $J 12673$ & $5 / 17 / 2006$ & 0.013 & $\mathrm{U}$ & 0.013 & 4 & $J 12673$ & $5 / 17 / 2006$ & 0.013 & $\mathrm{U}$ & 0.013 \\
\hline $\begin{array}{l}\text { Duplicate of } \\
\mathrm{J} 12673\end{array}$ & $\mathrm{~J} 12674$ & $5 / 17 / 2006$ & 0.013 & $U$ & 0.013 & $\begin{array}{c}\text { Duplicate of } \\
\text { J12673 }\end{array}$ & $J 12674$ & $5 / 17 / 2006$ & 0.013 & U & 0.013 \\
\hline 1 & $\mathrm{~J} 12670$ & $5 / 17 / 2006$ & 0.0055 & 5 & 0.013 & & & & & & \\
\hline 2 & $J 12671$ & $5 / 17 / 2006$ & 0.030 & & 0.013 & & & & & & \\
\hline 3 & 112672 & $5 / 17 / 2006$ & 0.013 & $\mathrm{U}$ & 0.013 & & TDL & & & 0.01 & \\
\hline 5 & $\mathrm{~J} 12675$ & $5 / 17 / 2006$ & 0.012 & $\mathrm{~J}$ & 0.013 & & Both $=$ & PQL? & No-St & $\mathrm{p}(\mathrm{ac}$ & ptable) \\
\hline 6 & $J 12676$ & $5 / 17 / 2006$ & 0.013 & $\mathrm{U}$ & 0.013 & Dupilcate & Both $>$ & XTDL? & & & \\
\hline 7 & $J 12677$ & $5 / 17 / 2006$ & 0.012 & $\mathrm{~s}$ & 0.013 & & $\mathrm{R}$ & $\mathrm{D}$ & & & \\
\hline
\end{tabular}

6 Statistical Computation Input Data

\begin{tabular}{|c|c|c|c|c|}
\hline & $\begin{array}{l}\text { Sample } \\
\text { Location }\end{array}$ & $\begin{array}{c}\text { HEIS } \\
\text { Number }\end{array}$ & $\begin{array}{l}\text { Sample } \\
\text { Date }\end{array}$ & $\begin{array}{c}\text { Aroclor-1254 } \\
\mathrm{mg} / \mathrm{kg}\end{array}$ \\
\hline 9 & 4 & J12673/J12674 & $5 / 17 / 2006$ & 0.0065 \\
\hline & 1 & J12670 & $5 / 17 / 2006$ & 0.0055 \\
\hline & 2 & $\mathrm{J12671}$ & $5 / 17 / 2006$ & 0.030 \\
\hline 2 & 3 & $\mathrm{~J} 12672$ & $5 / 17 / 2006$ & 0.0065 \\
\hline 3 & 5 & J12675 & $5 / 17 / 2006$ & 0.012 \\
\hline 4 & 6 & $\sqrt{12676}$ & $5 / 17 / 2006$ & 0.0065 \\
\hline 5 & 7 & $\mathrm{J12677}$ & $5 / 17 / 2006$ & 0.012 \\
\hline & 8 & $J 12678$ & $5 / 17 / 2006$ & 0.013 \\
\hline 7 & 9 & J12679 & $5 / 17 / 2006$ & 0.014 \\
\hline 8 & 10 & $\mathrm{~J} 12680$ & $5 / 17 / 2006$ & 0.013 \\
\hline
\end{tabular}

29 Statistical Computations

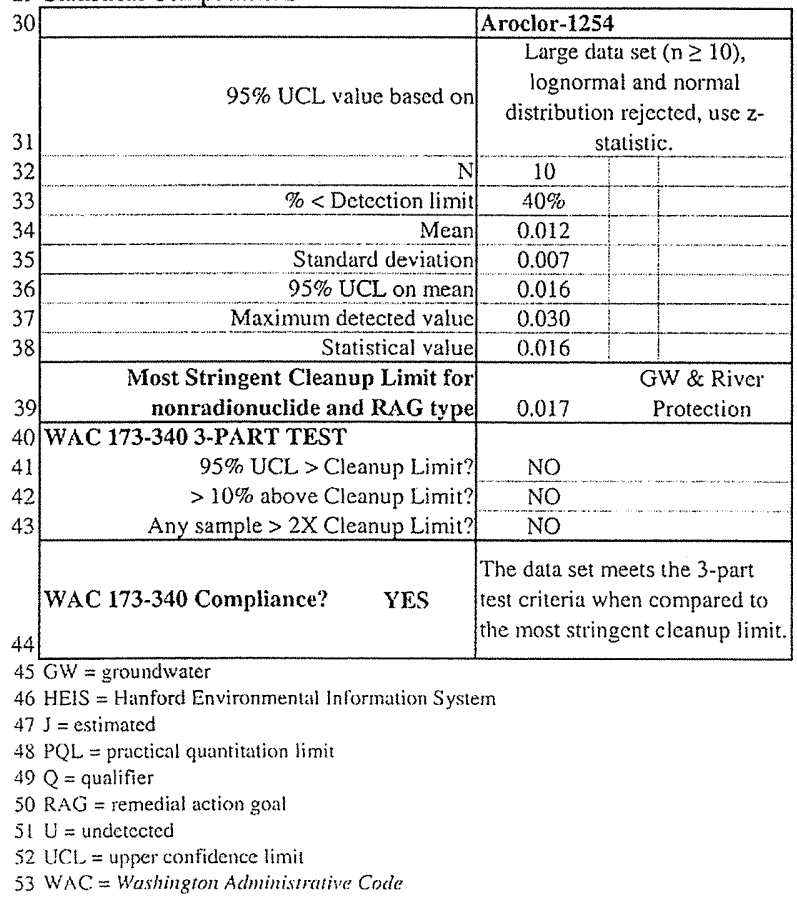


CALCULATION SHEET

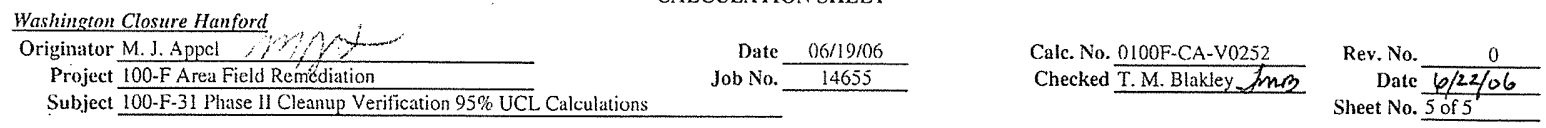

Ecology Software (MTCAStat) Results

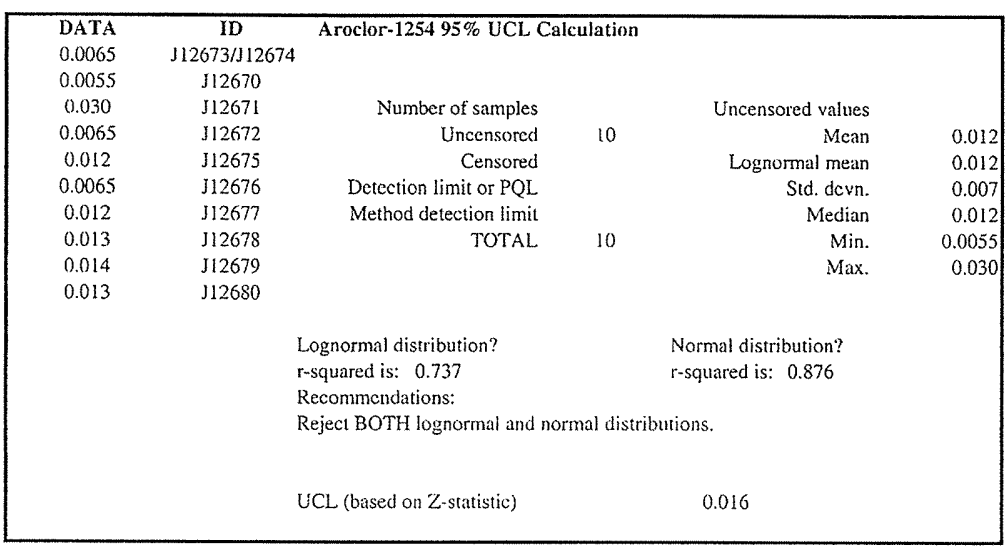

$\mathrm{PQL}=$ practical quantitation limi

UCL $=$ upper confidence limit 
ATTACHMENT 1

Washingten Closure Hanford

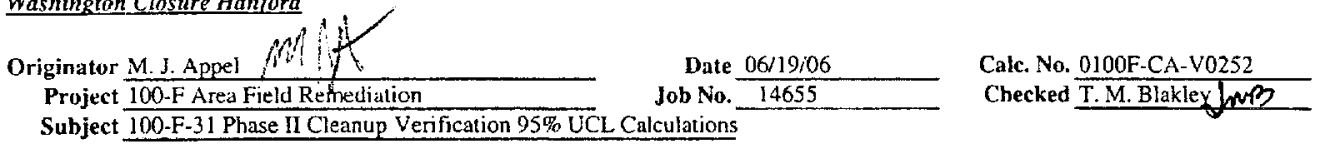

Rev. No. 0

Date $6 \longdiv { 2 2 / 0 6 }$ Subject 100-F-31 Phase II Cleanup Verification 95\% UCL Calculations

\begin{tabular}{|c|c|c|c|c|c|c|c|c|c|c|c|c|c|c|}
\hline \multirow{2}{*}{$\begin{array}{c}\text { Sampling } \\
\text { Area }\end{array}$} & \multirow{2}{*}{$\begin{array}{c}\text { HEIS } \\
\text { Number }\end{array}$} & \multirow{2}{*}{$\begin{array}{c}\text { Sample } \\
\text { Date }\end{array}$} & \multicolumn{3}{|c|}{ Aroclor-1016 } & \multicolumn{3}{|c|}{ Aroclor-1221 } & \multicolumn{3}{|c|}{ Aroclor -1232} & \multicolumn{3}{|c|}{ Aroclor -1242} \\
\hline & & & $\mathrm{mg} / \mathrm{kg}$ & $Q$ & PQL & $\mathrm{mg} / \mathrm{kg}$ & $Q$ & PQI & $\mathrm{mg} / \mathrm{kg}$ & 0 & POI & $\mathrm{mp} / \mathrm{kg}$ & 0 & POL \\
\hline 1 & $\mathrm{~J} / 2670$ & $5 / 17 / 2006$ & 0.013 & $\mathrm{U}$ & 0.013 & 0.013 & $\overrightarrow{\mathrm{V}}$ & 0.013 & 0.013 & U & 0.013 & 0.013 & $\frac{x}{\mathrm{U}}$ & 0.013 \\
\hline 2 & J12671 & $5 / 17 / 2006$ & 0.013 & $\mathrm{U}$ & 0.013 & 0.013 & $\mathrm{U}$ & 0.013 & 0.013 & $\mathrm{U}$ & 0.013 & 0.013 & $\bar{U}$ & 0.013 \\
\hline 3 & $\mathrm{~J} / 2672$ & $5 / 17 / 2006$ & 0.013 & $U$ & 0.013 & 0.013 & $\mathrm{U}$ & 0.013 & 0.013 & $\mathrm{U}$ & 0.013 & 0.013 & $\mathrm{U}$ & 0.013 \\
\hline 4 & $j 12673$ & $5 / 17 / 2006$ & 0.013 & $\mathrm{U}$ & 0.013 & 0.013 & U & 0.013 & 0.013 & $\mathrm{U}$ & 0.013 & 0.013 & $\mathrm{U}$ & 0.013 \\
\hline $\begin{array}{l}\text { Duplicate } \\
\text { of J12673 }\end{array}$ & $\mathrm{J} 12674$ & $5 / 17 / 2006$ & 0.013 & $\mathrm{U}$ & 0.013 & 0.013 & $\mathrm{U}$ & 0.013 & 0.013 & $\mathrm{U}$ & 0.013 & 0.013 & $\mathrm{U}$ & 0.013 \\
\hline 5 & J12675 & $5 / 17 / 2006$ & 0.013 & $\mathrm{U}$ & 0.013 & 0.013 & U & 0.013 & 0.013 & $\mathrm{U}$ & 0.013 & 0.013 & $\mathrm{U}$ & 013 \\
\hline 6 & $\mathrm{~J} 12676$ & $5 / 17 / 2006$ & 0.013 & $U$ & 0.013 & 0.013 & $\mathrm{U}$ & 0.013 & 0.013 & $U$ & 0.013 & 0.013 & $\mathrm{U}$ & 0.013 \\
\hline 7 & $\mathrm{~J} 12677$ & $5 / 17 / 2006$ & 0.013 & $\mathrm{U}$ & 0.013 & 0.013 & $U$ & 0.013 & 0.013 & $\mathrm{U}$ & 0.013 & 0.013 & $\mathrm{U}$ & 0.013 \\
\hline 8 & $\mathrm{~J} 12678$ & $5 / 17 / 2006$ & 0.013 & $\mathrm{U}$ & 0.013 & 0.013 & $\mathrm{U}$ & 0.013 & 0.013 & U & 0.013 & 0.013 & $\mathrm{U}$ & 0.013 \\
\hline 9 & $\mathrm{~J} 12679$ & $5 / 17 / 2006$ & 0.013 & $\mathrm{U}$ & 0.013 & 0.013 & $\mathrm{U}$ & 0.013 & 0.013 & $\mathrm{U}$ & 0.013 & 0.013 & $\mathrm{U}$ & 0.013 \\
\hline 10 & $\mathrm{J12680}$ & $5 / 17 / 2006$ & 0.013 & $\bar{U}$ & 0.013 & 0.013 & $\mathrm{U}$ & 0.013 & $0.0 \mathrm{I} 3$ & $\mathrm{U}$ & 0.013 & 0.013 & $\overrightarrow{\mathrm{U}}$ & 0.013 \\
\hline
\end{tabular}

15

\begin{tabular}{|c|c|c|c|c|c|c|c|c|c|c|c|c|}
\hline & \multirow{2}{*}{$\begin{array}{c}\text { Sampling } \\
\text { Area }\end{array}$} & \multirow{2}{*}{$\begin{array}{c}\text { HEIS } \\
\text { Number }\end{array}$} & \multirow{2}{*}{$\begin{array}{c}\text { Sample } \\
\text { Date }\end{array}$} & \multicolumn{3}{|c|}{ Aroclor -1248} & \multicolumn{3}{|c|}{ Arocior-1254 } & \multicolumn{3}{|c|}{ Aroclor-1260 } \\
\hline & & & & $\mathrm{mg} / \mathrm{kg}$ & $Q$ & PQL & $\mathrm{mg} / \mathrm{kg}$ & $Q$ & $\mathrm{PQL}$ & $\mathrm{mg} / \mathrm{kg}$ & Q & PQL \\
\hline & 1 & $\mathrm{~J} 12670$ & $5 / 17 / 2006$ & 0.013 & $\mathrm{U}$ & 0.013 & 0.0055 & I & 0.013 & 0.013 & $\mathrm{U}$ & 0.013 \\
\hline & 2 & $\mathrm{~J} 12671$ & $5 / 17 / 2006$ & 0.013 & $\mathrm{U}$ & 0.013 & 0.030 & & 0.013 & 0.013 & $\mathrm{U}$ & 013 \\
\hline & 3 & $\mathrm{~J} 12672$ & $5 / 17 / 2006$ & 3 & $\vec{U}$ & 3 & 3 & $\mathrm{U}$ & & & $\mathrm{U}$ & 913 \\
\hline & 4 & $\mathrm{~J} 12673$ & $5 / 17 / 2000$ & 0.013 & $\underline{U}$ & 0.013 & .013 & U & 0.013 & 0.013 & U & 0.013 \\
\hline & $\begin{array}{l}\text { Duplicate } \\
\text { of } 12673\end{array}$ & 512674 & $5 / 17 / 2006$ & 0.013 & U & 0.013 & 0.013 & U & 0.013 & 0.013 & $\mathrm{U}$ & 0.01 \\
\hline & 5 & $\$ 12675$ & $5 / 17 / 2006$ & 0.013 & $\mathrm{U}$ & 0.013 & 0.012 & $\mathrm{~J}$ & 0.013 & 13 & $\mathrm{U}$ & 0.013 \\
\hline & 6 & 512676 & $5 / 17 / 2006$ & 0.013 & $\mathrm{U}$ & 0.013 & 0.013 & 0 & 0.013 & 0.013 & $\mathrm{U}$ & 0.013 \\
\hline & 7 & 112677 & $5 / 17 / 2006$ & 0.013 & $\mathrm{U}$ & 0.013 & 0.012 & $\mathbf{J}$ & 0.013 & 0.013 & $\mathrm{U}$ & 0.013 \\
\hline & 8 & 512678 & $5 / 17 / 2006$ & 0.013 & $\mathrm{U}$ & 0.013 & 0.013 & $\mathbf{J}$ & 0.013 & 0.013 & $\mathrm{U}$ & 0.013 \\
\hline & 9 & $\mathrm{J12679}$ & $5 / 17 / 2006$ & 0.013 & $\mathrm{U}$ & 0.013 & 0.014 & & 0.013 & 0.013 & $\mathrm{U}$ & 0.013 \\
\hline & 10 & J12680 & $5 / 17 / 2006$ & 0.013 & $\mathrm{U}$ & 0.013 & 0.013 & J & 0.013 & 0.013 & $\mathrm{U}$ & 0.013 \\
\hline
\end{tabular}

30 Note: Data qualified with a 1 are considered acceptable values.

31 HEIS = Hanford Environmental Information System

$32 \mathrm{~J}=$ estimated

$33 \mathrm{PCB}=$ polychlorinated biphenyl

$34 \mathrm{PQL}=$ practical quantification limit

$35 \mathrm{U}=$ undelected

\begin{tabular}{|c|c|c|c|}
\hline Attachment & 1 & Sheet No. & 1 of 1 \\
\hline Originator & M. J. Appel & Dute & $06 / 19 / 06$ \\
\hline Checked & T. M. Blakley & Date & \\
\hline Calc. No. & $0100 \mathrm{~F}-\mathrm{CA}-\mathrm{V} 0252$ & Rev. No. & 0 \\
\hline
\end{tabular}




\section{APPENDIX C \\ HAZARD QUOTIENT AND CARCINOGENIC RISK CALCULATIONS}




\section{CALCULATION COVER SHEET}

Project Title 100-F Field Remediation Job No. 14655

\section{Area 100-F}

Discipline Environmental *Calc. No. 0100F-CA-V0262

Subject 100-F-31 Hazard Quotient and Carcinogenic Risk Calculation

Computer Program Excel Program No. Excel 2003 The attached calculations have been generated to document compliance with established cleanup levels. These
calculations should be used in conjunction with other relevant documents in the administrative record.

\section{Committed Calculation $\otimes \quad$ Preliminary $\square \quad$ Superseded $\square \quad$ Voided $\square$}

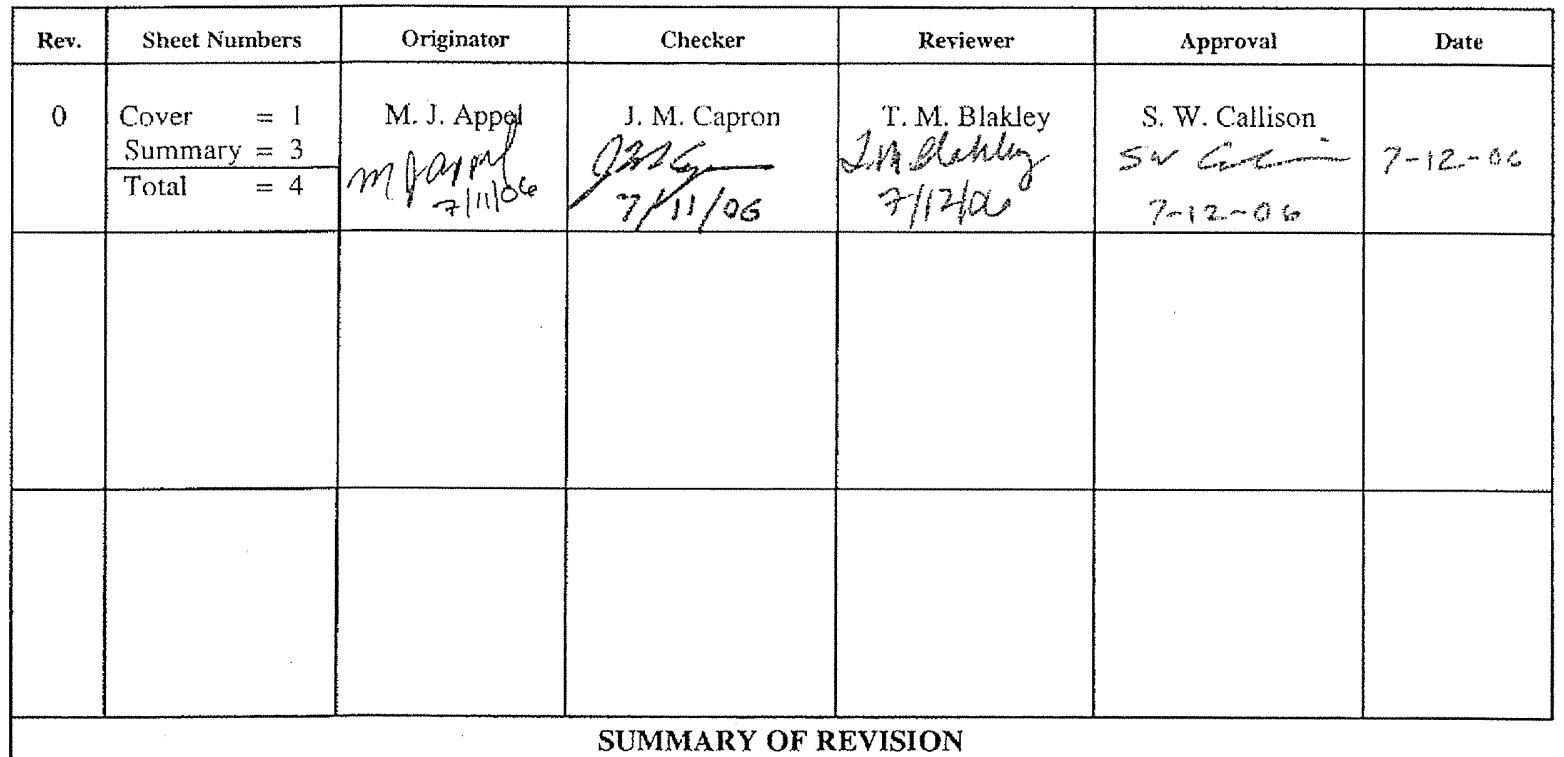

\begin{tabular}{|c|c|}
\hline & \\
\hline WCH-DE-018 (4/14/06) & *Obtain Calc. No. from R\&DC and Form from Intranet \\
\hline
\end{tabular}


Washington Closure Hanford, LLC

\begin{tabular}{|c|c|c|c|c|c|c|c|}
\hline Originator: & M. J. Appel & Date: & $7 / 11 / 06$ & Calc. No.: & $0100 \mathrm{~F}-\mathrm{CA}-\mathrm{V} 0262$ & Rey.: & 0 \\
\hline Project: & 100-F Field Remediation & Job No: & 14655 & Checked: & J. M. Capron $73 x$ & Date: & $7 / 11 / 06$ \\
\hline Subject: & \multicolumn{5}{|c|}{ 100-F-31 Hazard Quotient and Carcinogenic Risk Calculation } & \multicolumn{2}{|c|}{ Sheet No. 1 of 3} \\
\hline
\end{tabular}

\section{PURPOSE:}

Provide documentation to support the calculation of the hazard quotient (HQ) and carcinogenic (excess, cancer) risk for the 100-F-31 Remaining Sites Verification Package (WCH 2006). In accordance with the remedial action goals (RAGs) in Remedial Design Report/Remedial Action Work Plan for the 100 Areas (RDR/RAWP) (DOE-RL 2005), the following criteria must be met:

1) An HQ of $<1.0$ for all individual noncarcinogens

2) A cumulative HQ of $<1.0$ for noncarcinogens

3) An excess cancer risk of $<1 \times 10^{-6}$ for individual carcinogens

4) A cumulative excess cancer risk of $<1 \times 10^{-5}$ for carcinogens.

\section{GIVEN/REFERENCES:}

1) DOE-RL, 2005, Remedial Design Report/Remedial Action Work Plan for the 100 Areas, DOE/RL-96-17, Rev. 5, U.S. Department of Energy, Richland Operations Office, Richland, Washington.

2) EPA, 1994, Guidance Manual for the Integrated Exposure Uptake Biokinetic Model for Lead in Children, EPA/540/R-93/081, Publication No. 9285.7, U.S. Environmental Protection Agency, Washington, D.C.

3) WAC 173-340, "Model Toxics Control Act - Cleanup," Washington Administrative Code, 1996.

4) WCH, 2006, Waste Site Reclassification Form 2006-033, and Attachment Remaining Sites Verification Package for the 100-F-31, 144-F Sanitary Sewer System, Washington Closure Hanford, Richland, Washington.

\section{SOLUTION:}

1) Generate an HQ for each noncarcinogenic constituent detected above background and compare it to the individual HQ of <1.0 (DOE-RL 2005).

2) Sum the HQs and compare this value to the cumulative HQ of $<1.0$.

3) Generate an excess cancer risk value for each carcinogenic constituent detected above background and compare it to the excess cancer risk of $<1 \times 10^{-6}$ (DOE-RL 2005).

4) Sum the excess cancer risk values and compare to the cumulative cancer risk of $<1 \times 10^{-5}$. 
Washington Closure Hanford, L.LC CALCULATION SHEET

\begin{tabular}{|c|c|c|c|c|c|c|c|}
\hline Originator: & M. J. Appel & Date: & $7 / 11 / 06$ & Calc. No.: & $0100 \mathrm{~F}-\mathrm{CA}-\mathrm{V} 0262$ & Rev: & 0 \\
\hline Project: & 100-F Ficld Remediacion & Job No: & 14655 & Checked: & 5. M. Capron Sose & Date: & $7 / 11 / 06$ \\
\hline Subject: & \multicolumn{5}{|c|}{ 100 F-31 Hazard Quotient and Carcinogenic Risk Calculation } & \multicolumn{2}{|c|}{ Sheet No. 2 of 3} \\
\hline
\end{tabular}

\section{METHODOLOGY:}

2

Hazard quotient and carcinogenic risk calculations were computed for the 100-F-31 waste site as a whole, using the statistical value for each analyte detected above background in the data set. Of the contaminants of concern (COC) and the contaminants of potential concern (COPC) for the site, boron requires the $\mathrm{HQ}$ and risk calculations because this analyte was detected and a Washington State or Hanford Site background value is not available. Lead was included because it was quantified at a concentration above the Washington State or Hanford Site background value. Hexavalent chromium, aroclor-1254, and multiple semivolatile analytes are included because they were detected by laboratory analysis and could not be attributed to natural occurrence. All other site nonradionuclide COCs/COPCs were not detected or were detected below background levels. An example of the HQ and risk calculations is presented below:

1.) For example, the maximum value for boron is $2.7 \mathrm{mg} / \mathrm{kg}$, divided by the noncarcinogenic RAG value of $16,000 \mathrm{mg} / \mathrm{kg}$ (boron is identified as a noncarcinogen in WAC 173-340-740[3]), is $1.7 \times 10^{-4}$. Comparing this value, and all other individual values, to the requirement of $<1.0$, this criterion is met.

2) After the HQ calculation is completed for the appropriate analytes, the cumulative HQ is obtained by summing the individual values. The sum of the HQ values is $4.8 \times 10^{-2}$. Comparing this value to the requirement of $<1.0$, this criterion is met.

3) To calculate the excess cancer risk, the maximum value is divided by the carcinogenic RAG value, then multiplied by $1 \times 10^{-6}$. For example, the maximum value for aroclor- 1254 is $0.016 \mathrm{mg} / \mathrm{kg}$; divided by $0.5 \mathrm{mg} / \mathrm{kg}$, multiplied as indicated is $3.2 \times 10^{-8}$. Comparing this value, and all other individual values, to the requirement of $<1 \times 10^{-6}$, this criterion is met.

4) After these calculations are completed for the carcinogenic analytes, the cumulative excess cancer risk is obtained by summing the individual values. The sum of the excess cancer risk values is $1.5 \times 10^{-6}$. Comparing this value to the requirement of $<1 \times 10^{-5}$, this criterion is met.

\section{RESULTS:}

1) List individual noncarcinogens and corresponding HQs $>1.0$ : None

2) List the cumulative noncarcinogenic $\mathrm{HQ}: 4.8 \times 10^{-2}$

3) List individual carcinogens and corresponding excess cancer risk $>1 \times 10^{-6}$ : None

4) List the cumulative excess cancer risk: $1.5 \times 10^{-6}$.

Table 1 shows the results of the calculations. 
Washington Closure Hanford, LLC.

\begin{tabular}{|c|c|c|c|c|c|c|c|}
\hline Origi & M. J. Appel & Date: & $7 / 11 / 06$ & Calc. No.: & $0100 \mathrm{~F}-\mathrm{CA}-\mathrm{V} 0262$ & Rev.: & 0 \\
\hline Project: & 100-F Field Remediation & Job No: & 14655 & Checked: & J. M. Capron $y^{\text {sench }}$ & Date: & $7 / 11 /$ \\
\hline Subject: & \multicolumn{5}{|c|}{ 100-F-31 Hazard Quotient and Carcinogenic Risk Calculation } & \multicolumn{2}{|c|}{ Sheet No. 3 of 3} \\
\hline
\end{tabular}

Table 1. Hazard Quotient and Excess Cancer Risk Results for the 100-F-31 Waste Site.

1

3

4

5

6

7

8

9

10

11

12

13

14

\section{CONCLUSION:}

This calculation demonstrates that the 100-F-31 waste site meets the requirements for the hazard quotients and carcinogenic (excess cancer) risk as identified in the RDR/RAWP (DOE-RL 2005). 